Portland State University

PDXScholar

1978

\title{
Upton Sinclair and the 1934 California gubernatorial election
}

Patricia Lucy Hill

Portland State University

Follow this and additional works at: https://pdxscholar.library.pdx.edu/open_access_etds

Part of the Political History Commons, and the United States History Commons Let us know how access to this document benefits you.

\section{Recommended Citation}

Hill, Patricia Lucy, "Upton Sinclair and the 1934 California gubernatorial election" (1978). Dissertations and Theses. Paper 2937.

https://doi.org/10.15760/etd.2931

This Thesis is brought to you for free and open access. It has been accepted for inclusion in Dissertations and Theses by an authorized administrator of PDXScholar. Please contact us if we can make this document more accessible: pdxscholar@pdx.edu. 
AN ABSTRACT OF THE THESIS OF Patricia Lucy Hill for the Master of Science in Teaching in history presented November 21, 1978.

Title: Upton Sinclair and the 1934 California Gubernatorial Election. APPROVED BY MEMBERS OF THE THESIS COMMITTEE:

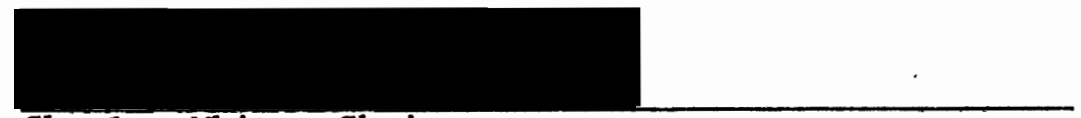

Charles White, Chairman
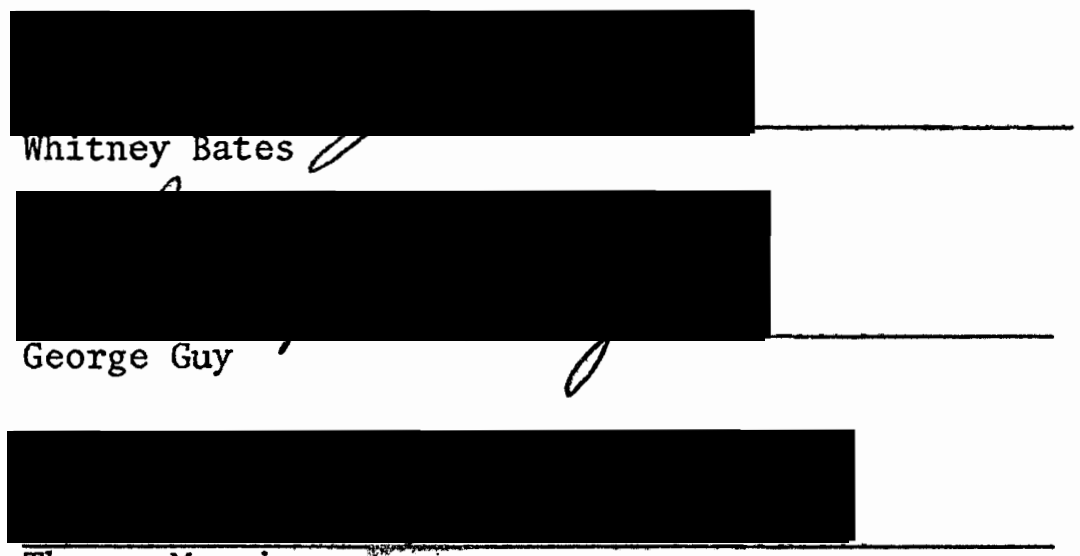

Thomas Morris

This thesis attempts to ascertain whether Upton Sinclair's Democratic nomination for governor of California in 1934 caused the resurgence of the Democratic Party in California, or whether his nomination was a product of that party's resurgence between 1928 and 1942 . Given Sinclair's decision on the unsuitability of the Socialist Party, were his judgements that: (1) the Democratic Party was in resurgence and, (2) it was moving to the left, sound ones? To make these determinations the thesis investigates why Sinclair rushed to capture the Democratic nomination, exploring his methods and techniques and those 
used to defeat him. It also examines the reactions of the Democratic Party leaders of the right and left wings toward the Sinclair candidacy, and analyzes the primary and general election returns--citing differences and similarities between Northern and Southern California--which predicate that Sinclair's decision was: (1) based on faulty judgement, and (2) based on an inaccurate appraisal of the position of the Democratic Party.

Sources used in this thesis are those accessible to public examination. The author used materials available locally, through interlibrary loan or on microfilm, and several trips were made to Southern California to consult information not available in Oregon.

Materials used include all available printed sources: books, government publications, manuscripts, pamphlets, periodicals, and special collections. Many of the sources were obtained through public and university libraries in California, including the Bancroft Library of the University of California, Occidental College Library, and the University of California at Los Angeles Library.

The result of the research gives substantial evidence that Upton Sinclair was the product and not the cause of the Democratic Party's resurgence in California. The factors which made Sinclair's candidacy possible included: (1) increased Democratic Party registration, (2) 1932 election victory of Franklin Roosevelt and his New Deal, (3) voter dissatisfaction with the Republican Party leadership "status quo" politics, and (4) the Democratic Party's transformation into a "cause" oriented organization, with an alternative solution to the depression. The resurgence of the party forced Democrats to look for new and innovative programs, programs which would bring an end to the ills 
of society.

Despite the Democratic Party resurgence in California, party philosophy and ideology did not move leftward on the political spectrum in 1934. Sinclair failed to recognize the strength of the two party system and the allegiance of party regulars to the traditional party organization. Democrats were suspicious of the unorthodox "panacea and pension politics" of Upton Sinclair. Various factors contributed to the failure of Sinclair and EPIC, the most important of which were:

desertions by local, state, and national Democratic Party leaders and members, (2) Sinclair's failure to disassociate himself and EPIC from the Socialist Party, (3) voter distrust and fear of Sinclair and his plan, (4) widespread denunciation of EPIC within the financial and industrial sectors of the state, and (5) campaign rhetoric which centered on personalities rather than issues. While the Democratic Party officials sponsored the "radical" EPIC program, party regulars remained committed to traditional principles and programs. 
UPTON SINCLAIR AND THE 1934 CALIFORNTA

GUBERNATORIAL ELECTION

by

PATRICIA LUCY HILL

A thesis submitted in partial fulfillment of the requirements for the degree of

\author{
MASTER OF SCIENCE IN TEACHING \\ in \\ HISTORY
}

Portland State University

1978 
TO THE OFFICE OF GRADUATE STUDIES AND RESEARCH:

The members of the Committee approve the thesis of Patricia Lucy Hill presented November 21, 1978.

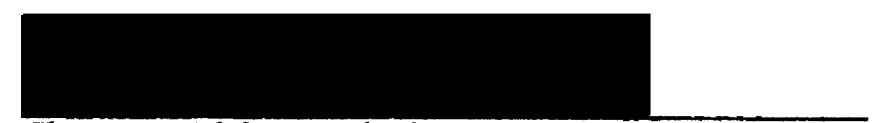

Charles White, Chairman
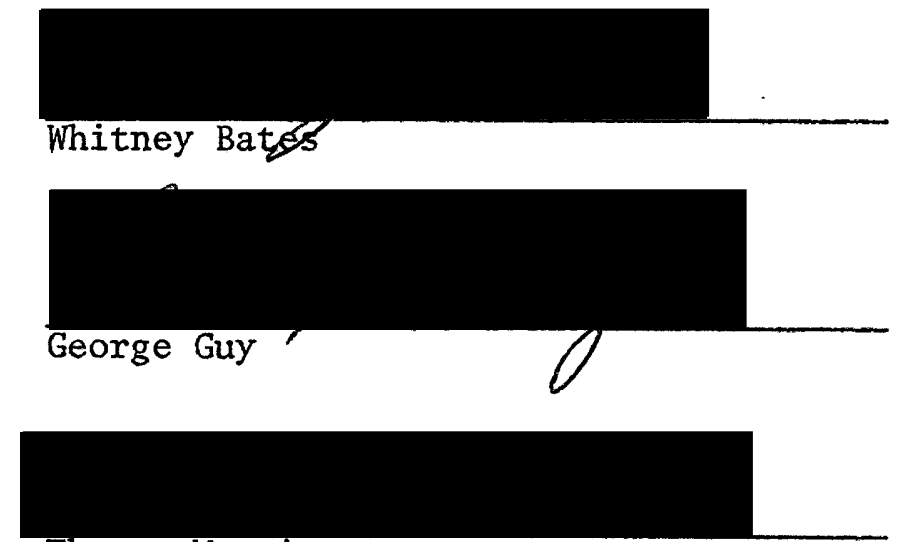

Thomas Morris

APPROVED :

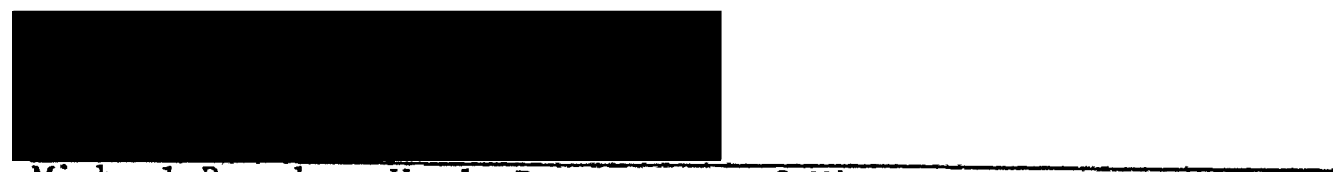

Michael Reardon, Head, Department of History 
TABLE .OF CONTENTS

PAGE

LIST OF TABLES

LIST OF FIGURES .

\section{CHAPTER}

I INTRODUCTION • • • • • • • • • • • • • • •

II BACKGROUND: CALIFORNIA AND THE EPIC MOVEMENT 6

Depression Years in California . . . . . . . 6

State Politics: Republicans Versus Democrats . . 8

Upton Sinclair . • • • • • • . • • . . 12

EPIC Plan . . . . . . . . . . . . . . . 18

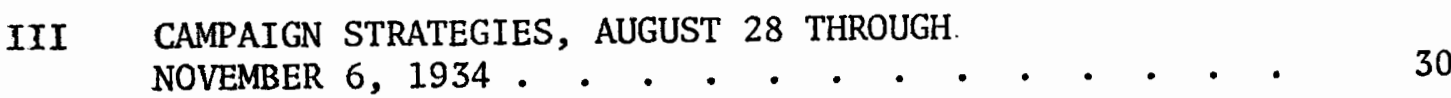

EPIC Strategy . • • . • • • • . • • • . 31

Campaign Strategies Used to Defeat Sinclair . . . 38

Communism and Radicalism

Flight of Capital.

Influx of Transients

Use of Sinclair's Words

EPIC Plan

Split in the Democratic Party

Tom Mooney Case

Literary Digest Po11

Vote Fraud

Summary 
CHAPTER.

PAGE

IV POLITICAL REACTIONS AND . ATTITUDES . • . • . . . . 70

Reaction of State:Democratic Leaders . . . . . 71

Reaction of County and Local Democratic Leaders . 77

Reaction of the National Democratic Leaders . . . 81

Reaction of the Republican Party Leaders . . . . 90

Socialist Party . . . . . . . . . . . . 92

Communist Party . . . . . . . . . . . . 95

Summary • • • • • • • • • • • • • • • 97

$\mathrm{V}$ RESULTS OF THE 1934 PRIMARY AND GENERAL ELECTIONS . . 100

Registration . . . . . . . . . . . . . 100

Primary Election . . . . . . . . . . . 106

Summary

General Election . . . . . . . . . . . 116

Summary

VI CONCLUSION: THE SIGNIFICANCE OF THE EPIC

MOVEMENT • • • • . • • • • • • • • • . 133

Reasons for Defeat . . . . . . . . . . 134

Effect of the EPIC Movement . . . . . . . 135

VII A COMPREHENSIVE RESOURCE GUIDE ON UPTON SINCLAIR AND THE 1934 CALIFORNIA GUBERNATORIAL ELECTION .

BIBLIOGRAPHY 


\section{LIST OF TABLES}

TABLE

PAGE

I California Voter Registration and Population,

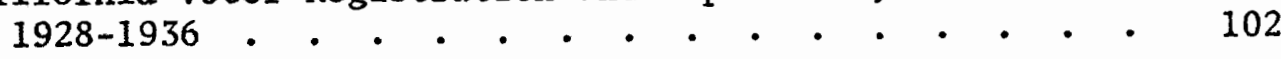

II Party Registration Behavior, 1930-1940 • • • • • $\quad$ - 104

III Regional Distribution of the Vote for Governor, November 6, 1934 . 


\section{LIST OF FIGURES}

FIGURE

PAGE

1. The Counties of California . . . . . . . . . 101

2. Distribution of Republican Primary Votes . . • • • 109

3. Distribution of Democratic Primary Votes . . . . . . 111

4. Distribution of General Election Votes . . . . • • • 118 
CHAPTER I

\section{INTRODUCTION}

On August 28, 1934, Upton Sinclair, noted Socialist author and orator, captured the Democratic nomination for governor of California. Sinclair's candidacy produced one of the most bitterly contested elections ever held in California, as well as one of the most unusual election campaigns in American political history. The campaign became a fight between the "reformists" and "conservatives" for political dominance of the State of California. The time was ripe for the Democratic Party in California, and, due to the party's increased registration strength and the ineffectiveness of the Republican Party in dealing with the problems of the depression, the voters searched for new leaders and ideas. In response came the candidacy of Upton Sinclair, the product of the Democratic Party's resurgence in California between 1928 and 1942.

THE PROBLEM

Statement of the Problem

This thesis attempts to ascertain whether Upton Sinclair's Democratic nomination for governor of California in 1934 was caused by the resurgence of the Democratic Party in California, or whether his nomination was a product of that party's resurgence between 1928 and 1942 . Given Sinclair's decision on the unsuitability of the Socialist Party, were his judgements that: (1) the Democratic Party was in resurgence; and (2) it was moving to the left, sound ones? To make these 
determinations the thesis investigates why Sinclair rushed to capture the Democratic nomination, and explores his methods and techniques and those used to defeat him. It also examines the reactions of the Democratic. Party leaders of the right and left wings toward the Sinclair candidacy, and analyzes the primary and general election returns-citing differences and similarities between Northern and Southern California--which predicate that Sinclair's decision was: (1) based on faulty judgement, and (2) based on an inaccurate appraisal of the position of the Democratic Party.

Limitations of the Problem

Sources used in this thesis are limited to those accessible to public examination. All available local materials were consulted, with additional information retrieved through interlibrary loan, on microfilm, and through several trips to selected California research centers. Through this process an attempt was made to broaden the author's know1edge of Upton Sinclair and his bid for the governorship of California between August 28, and November 6, 1934.

Importance of the Study

The Democratic Party had not elected a governor in California since 1896. The party through the years had lacked leadership and unity, however conditions in California in 1934 indicated the possibility of a Democratic victory. Democratic strength was indicated by Roosevelt's New Deal victory in 1932, increased Democratic Party registration in California, and voter dissatisfaction with Republican "status quo" politics. As a result of Sinclair's primary landslide, all indications pointed to the election of a Democratic governor. Yet, that victory was 
never attained due to a forceful campaign to spread fear among the voters, as well as disunity and poor leadership within the Democratic Party in California.

\section{ORGANIZATION}

In order to understand the impact of Upton Sinclair's candidacy for governor of California, a brief history of the socioeconomic and political events leading to the 1934 election campaign, together with an examination of the life and philosophy of Upton Sinclair, and a discussion of the "End Poverty in California" ${ }^{1}$ program and its origination, is attempted. Next, an examination of Sinclair's EPIC campaign strategy and the methods used by the opposition to defeat him are presented. The reactions and attitudes of the Democratic, Republican, Socialist, and Communist Party leaders of the man and his campaign are discussed. Then, a chapter is provided for the analysis of the primary and general election returns. Special attention is given to the regional differences and similarities between Northern and Southern California. The significance of the EPIC movement is then examined, with conclusions presented on why EPIC was defeated, its effect on California politics, and the role played by Upton Sinclair in the Democratic Party. Finally, a comprehensive guide of resources available on the west coast is provided for future use in recreational or research endeavors.

$1_{\text {Hereinafter Upton Sinclair's "End Poverty in California" }}$ program will be referred to as EPIC. 
SOURCES AND PROCEDURES

Sources

Sources used included all available printed material: books, government publications, manuscripts, pamphlets, periodicals, and special collections. Much of the data was obtained through public and university libraries in California. The most important libraries consulted were: California State Library; California State University libraries at Chico and Northridge; Occidental College Library; University of California libraries at Berkeley and Los Angeles; and University of Southern California Doheny Library.

Investigation of Upton Sinclair and the 1934 gubernatorial election utilized both primary and secondary sources. Substantial thesis documentation was obtained from the J.F.T. O'Connor diary, Thomas J. Mooney pamphlet collection, and R.V. Taggert scrapbook of Republican documents, Bancroft Library of the University of California; Elmer Belt collection, Occidental College Library; and John Randolph and Dora Haynes collection, University Research Library of the University of California at Los Angeles. Other important secondary materials used included many of Sinclair's works as well as the following newspapers: the EPIC News, the Los Angeles Times, the New York Times, and the San Francisco Chronicle.

$\underline{\text { Procedure }}$

The procedure of this study was to read all available material on Upton Sinclair in order to gain a general knowledge of Sinclair on his early life, on his social and economic philosophy, and on his EPIC plan. Secondly, registration data were consulted in an attempt to 
trace the resurgence of the Democratic Party in California. Election returns were analyzed to learn whether or not Sinclair's decision to run in the 1934 gubernatorial election was based on sound judgement. Newspapers and campaign materials were also examined to cite the methods used to defeat Sinclair, and indicate the reaction of party leaders toward his candidacy. 


\section{CHAPTER II}

BACKGROUND: CALIFORNIA AND THE EPIC MOVEMENT

The depression reached its lowest point in the summer of 1934, the state plagued by a deep economic crisis. The California State Emergency Relief Administration reported in the Los Angeles Times on June 29, that the "known or registered" unemployed in California numbered 450,000, with known dependents of 800,000 , a total of $1,220,000$ persons, of the whole population of the state. ${ }^{2}$ This number constituted only the persons who were totally unemployed; it does not count the thousands who were working on a part-time basis. Employment in California had dropped over fiftyfive percent, while payrolls went down sixty-eight percent from August 1929 to June $1933 .^{3}$

Conditions in Southern California, Los Angeles County in particular, was especially hard hit by the depression. Of the state's total unemployed population, 349,039 resided in Los Angeles County, or about one of every seven persons. ${ }^{4}$ Southern California with fifty-four percent of the state's population, supported over seventy percent of the state's welfare recipents between July 1, 1933 and June 30, 1934 . Onefifth of the residents of Los Angeles County were on relief, receiving an

\section{Walton Bean, California: An Interpretive History (New York:} McGraw-Hil1, 1973), p. 409.

3"Monthly Bulletin on Relief Statistics," California State Emergency Relìef Administration, I (August, 1934), 39.

${ }^{4}$ Carey McWilliams, "Upton Sinclair and His EPIC," New Republic, August 15, 1934, p. 39. 
average monthly payment of $\$ 16.50$. per family. ${ }^{5}$ Upton Sinclair stated that according to the county records, there were 75,000 new charity cases in three months in Los Angeles County, each case involving 4.3 persons. There were more than 500,000 people who received public relief in the county during $1933 .^{6}$

By May 1934, Los Angeles County was supporting, with public funds, approximately 465,000 people, or one out of six residents. During a two week period in that month there was cited an increase of 4,000 charity cases. In addition during $1934, \$ 16,500,000$ was spent in taking care of these people. The Los Angeles Times on May 25, stated that the federal expenditures in California had amounted to more than $\$ 75,000,000$ to that date, with $\$ 60,000,000$ more authorized to be spent. This amount did not include any of the loans from the Farm. Credit Administration, Reconstruction Finance Corporation, or Home Owners Loan Corporation. ${ }^{7}$ The state, according to Sinclair, faced economic ruin unless the federal government provided additional monies and programs. ${ }^{8}$

Depressed conditions led to strikes and turmoil throughout the state. Farmers suffered as their income dropped from $\$ 623,103,000$ in 1929 to $\$ 371,965,000$ in 1932 , culminating in thousands of mortgage

\section{5 "Monthly Bulletin on Relief Statistics," p. 3.}

6Upton Sinclair, I, Governor of California and How I Ended Poverty: A True Story of the Future (New York: Farrar and Rinehart, 1933), pp. 12-13. "(Hereinafter referred to as I, Governor of California.)"

7 Upton Sinclair, Immediate EPIC: The Final Statement of the Plan (Los Angeles: End Poverty League, 1934), p. 4. "(Hereinafter referred to as Immediate EPIC.)" 
foreclosures. 9 Long standing exploitation of farm labor resulted in a series of strikes beginning in the fall of 1933, involving more than 14,000. workers in every important farming area of the state. ${ }^{10}$ A waterfront strike that began in June tied up all but one California port and resulted in the San Francisco general strike in July, which was inspired by accusations of "Red Menace" and "Communism" by the Hearst Press. The headquarters of many radical union groups were raided and disbanned by mobs. 11

Depression politics was the result of individuals' hopesin finding a solution to the deep economic crisis. "The times cried for new changes, political voices and political figures answered." California as well as the nation faced.

Poverty in the midst of plenty, great financial institutions plunged into bankruptcy, industrious forced into idleness, the thrifty reduced to want and world of opportunity transformed into a world of closed doors. 12

In response to this crisis came a period of "panacea and pension politics", of which EPIC was an outgrowth. While the depression created an environment in which a plan such as EPIC could be developed, it also generated the fears and suspicions that fostered a strong reactionary countermove. As a result the political campaign of 1934 became a battle between the reformists and conservative political factions of the state.

9 David Farrelly and Ivan Hinderaker, Politics of California: A Book of Readings (New York: Ronald Press Co., 1951), p. 74.

10"Monthly Bulletin on Relief Statistics," p. 26.

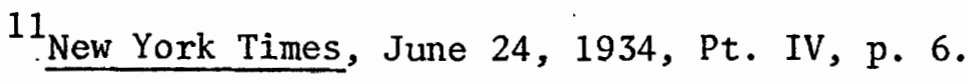

12 Warren A. Beck and David A. Williams, Califormia: A History of the Golden State (New York: Doubleday \& Co., 1972), p. 401. 
The political scene in Califormia had not always been ripe for a reformists movement such as EPIC. Traditionally California had been known as a Republican state. The struggle for political power had always been between the two factions of the Republican Party which had been controlled by leaders of the Southern Pacific Railroad from 1869 until 1910. William F. Herrin, legal counsel for the railroad, directed political activities in the state and maintained a close control over local and state politics between 1890 and 1910. This control amounted to domination of the Republican Party and, to some extent, of the Democratic Party as well. There were Southern Pacific candidates, often on both tickets, at each election. However, the "progressive revolution" of 1910 weakened Herrin's control over the Republican Party with the election of the Progressive Party standard bearer, Hiram W. Johnson, as governor. Johnson remained leader of the reform movement until his resignation to enter the United States Senate in 1917.

Conservative forces returned to dominate California politics in the election of 1922. The Republican Party became split over which faction, progressive or conservative, should govern the state. In 1926 the progressives returned to power under the leadership of C.C. Young; four years later the conservatives would win, led by James Rolph, Jr. ${ }^{13}$

By 1934 it began to look as if the Democratic Party might threaten the long period of Republican rule. The administrations of James Rolph and Frank Merriam (1931-39), together, constituted the "transition stage between the breakup of the intraparty rivalry of the

13 J.P. Harris, California Politics (New York: Thomas Y. Crowe 11,1975$),$ p. 69. 
Republican factions and the attempt to restore Democratic Party government."14 The Democrats also benefited by the 1932 Roosevelt lands1ide, in which William Gibbs McAdoo, former Secretary of Treasury under Wilson, and his son-in-1aw, won election as a Democrat to the United States Senate. Using federal patronage, McAdoo begun to rebuild the party in California. ${ }^{15}$ With increased registration, the Democratic Party had hopes for capturing the governorship and the state in the 1934 elections.

The Republican hegemony, which began in 1898 and lasted until 1958, was a powerful political force to contest. In California every governor since 1894, except Culbert 01son, had been a Republican. The Republican Party had also controlled the majority of political offices of the state and State legislature. Between 1894 and 1931, Republicans had taken thirteen of fifteen contests for seats in the United States Senate, and lost only two presidential elections in the period between 1884 and $1928 .^{16}$ Furthermore, it had always had a majority of registered voters in the state. The Democratic Party, however, elected only two men between 1890 and 1958 to the office of attorney general and were unable to elect a single person to the positions of secretary of state, treasurer, or comptroller. In the State legislature the Democrats had never elected more than three of eighty assemblymen. In three of the

\section{W.W. Crouch, California Government and Politics (New} Jersey: Prentice Ha11, 1967), p. 56.

${ }^{15}$ Don E. Fehrenbacker, A Basic History of California (New York: Van Nostrand Co., 1964), p. 77.

${ }^{16}$ Eugene C. Lee, California Votes, 1928-60 (Berkeley, Calif.: University of California, 1963), pp. A209-12. 
biennial elections the Democrats had failed to win a single seat out of twenty available positions! ${ }^{17}$

John R. Owens' book, Califormia Politics and Parties, cites many reasons for the "Republican ascendancy" in Calltornı. H1rst, tne Republicans were more effective in supporting their campaigns. Republ1can candidates were generally well known, and were rarely opposed by other Republicans in primary elections. Republicans also received more financial and organizational support than did Democrats. Second, Republicans often had the advantage of being incumbents. Then too, crossfiling helped Republicans, since party affiliation of each candidate appeared after his name on the primary ballot. Republicans, having controlled the State legislature, also followed the customary practice of gerrymandering the state to their advantage. Also, the majority of newspapers in the state favored the Republican Party. Henry Turner estimated that of Califomia's newspapers, eighty percent were Republican in orientation, ten percent Democratic, and ten percent independent. ${ }^{18}$

Robert Hennings offered additional insight as to why the Republican Party dominated California politics for so long in his article, "California Democratic Politics in the Period of Republican Ascendancy." Hennings cited the Republican strength as the result of successive failures in state elections since 1900, and migration and general prosperity of the times. The political factors which attributed to the

${ }^{17}$ Crouch, California Government and Politics, p. 267.

${ }^{18}$ Henry A. Turner and John A. Vieg; Governments and Politics of California (New York: McGraw-Hil1, 1967), pp. 46-48. 
Democrats' ineffectiveness were: (1) the nature of the established party leadership, and (2) party discord under the leadership of James D. Phelan. 19

Late in the summer of 1933, Upton Sinclair, writer and lifelong Socialist, received a letter from Gilbert Stevenson of Santa Monica, chairman of the Los Angeles County Central Committee of the Democratic Party:

I have asked a half dozen people to meet you at my office Thursday, August 31 at 7:00 o'clock p.m. My office is in the California Hotel opposite the Mirmar...20

The letter went on to suggest that Sinclair re-register as a Democrat and run for the nomination of that party for governor of California. 21 Stevenson urged that Sinclair formulate a definite program to deal with the depression.

Some of the leaders of the Democratic Party realized the necessity of strengthening programs and policies. To do so, they set out to formulate and adopt a program that was drastically different from that of the Republicans in order to attract the state's discontented and impoverished. Upton Sinclair, who had spent.a lifetime studying poverty and who had written on conditions in California, seemed the logical choice.

After deliberating on Stevenson's offer, Sinclair finally agreed to

${ }^{19}$ Robert E. Hennings, "California Democratic Politics in the Period of Republican Ascendancy," Pacific Historical Review, XXXI (August, 1962), 267.

${ }^{20}$ Reuben M. Borough, Challenge of Sinclair's EPIC (Los Angeles: By the Author, 1945), p. 10.

${ }^{21}$ Upt on Sinclair, I, Candidate for Governor: And How I Got Licked (Pasadena: By the Author, 1935), p. 6. 
prepare a program. On August 31, 1933, Sinclair presented his program in the office of the California Hotel in Santa Monica. He appeared before six members of the Sixtieth Assembly District delegation of the Los Angeles County Democratic Central Committee. This meeting began the "most unusual and bizarre gubernatorial campaign in California's political history." 22

Sinclair explained to the committee the plan he had formulated, calling it the "two year plan for California." 23 Sinclair declared, "Now we had a bad slump, and Franklin Roosevelt was casting about for ways to end it...to me the remedy was obvious." ${ }^{24}$ He told the committee that:

If I am your candidate for governor it will be for the purpose of putting my Two-Year Plan across. Let me make it plain that being Governor means nothing to me personally. I do not need fame. I do not need money. But I cannot enjoy the comforts of home... while I know that there are millions of others around me suffering for lack of the common necessities. ${ }^{25}$

Sinclair then proposed the campaign slogan "End Poverty in California", and suggested the bee as an emblem expressive of useful labor with the motto, "I produce, I defend." 26 Rob Wanger, editor of the Beverly Hills Script,

${ }^{22}$ Dewey Anderson, Voting in California (Washington, D.C.:

Public Affairs Institute, 1958), p. 12 .

${ }^{23}$ Arthur M. Schlesinger, Jr., Politics of Upheavel: The Age of Roosevelt (Boston: Houghton Mifflin Co., 1960), p. 112.

${ }^{24}$ Upton Sinclair, The Autobiography of Upton Sinclair

(New York: Harcourt, Brace \& World, 1962), p. 569.

${ }^{25}$ Sinclair, I, Governor of California, p. 18.

${ }^{26}$ Schlesinger, Politics of Upheavel: 'The Age of Rooseve1t, p. 114 . 
later drew a shield which portrayed the busy bee with the motto. 27 There was general discussion concerning the plan and, to Sinclair's surprise, the committee approved it. One of the members pointed out that the initials of the slogan spelled "EPIC", which was then used throughout the campaign. More than a year before the November general election, the California gubernatorial campaign of 1934 was under way.

To understand Upton Sinclair's EPIC plan for California, one needs to be familiar with Sinclair's background. He was born on September 20, 1878 in Baltimore, Maryland. His ancestors, on his father's side, were a naval family with a tradition of service in both Great Britain and the United States. While Upton's father chose to become a wholesale liquor salesman, Upton's earliest ambition was to attend the United States Naval Academy.

The Sinclairs were an aristocratic Southern family which had become impoverished as a result of the Civil War. His mother's family, the Hardens, was a wealthy Southern family upon whom the livelihood of the Sinclair's was dependent. Upton had always lived in the shadow of wealth, but had been denied the Iuxuries that money provided. Sinclair was forced to accept from other people the material necessities of life. "AII my life," he said, "I was faced by the contrast between riches and poverty and thereby impelled to think and ask questions!" 28 Sinclair

\footnotetext{
${ }^{27}$ Sinclair, I, Governor of California, p. 19.

${ }^{28}$ Editorial, EPIC News, May 28, 1934, p. 3.
} 
further stated to Floyd Dell:

I thought the problem over and reported my psychology as that of a poor relation. It had been my fate...to live in the presence of wealth which belonged to others. 29

As a result of his economic dependence, Sinclair turned to the Socialist Party.

In 1888, the Sinclairs moved to New York City. Upton graduated from the College of the City of New York in 1887, "comfortably near the bottom of his class." 30 He then registered in the graduate law program at Columbia University. Sinclair later changed his classification to that of "special student" and aimed at a master's degree. He never received his degree, but stayed at Columbia for four years taking only courses which interested him and which he felt where valuable. 31

At the age of twenty-one Sinclair was married, and, a year later had a son. His family lived in poverty for several years, Sinclair trying to support them through the sale of his writings. During this period Sinclair, having experienced the struggles of poverty, became more realistic in his attitudes toward life and its problems. However, as Reuben Borough, a longtime friend of Sinclair, pointed out, "His own early struggles with poverty gave him an understanding of the problems of the poor that he has never forgotten." ${ }^{32}$ Although Sinclair came from a poor background, he felt it was his duty as a Southern gentleman to help

29 "California Climax," Time, October 22, 1934, p. 13.
30 Floyd De11, Upton Sinclair: A Study in Social Protest

(New York: Prentice-Ha11, 1970), p. 49.

${ }^{31}$ Sinclair, The Autobiography of Upton Sinclair, p. 61.

32 Rockwell D. Hunt, ed., California and Californians, Vol. 5: (San Francisco: Lewis Publishing Co., 1926), p. 166. 
others less fortunate than himself.

Sinclair's career gained national prominence in 1906 with his book, The Jungle, which described the serious conditions in the Chicago meatpacking industry. This book netted. $\$ 30,000$ which Sinclair invested in the organization of the New York Home Colony. Sinclair, with other families, lived in a communal environment in a building known as Helicon Hall, near Englewood, New Jersey. The building was destroyed by fire in 1907. Sinclair, financially hurt, started over again, only to invest in other "causes."

Sinclair remained in the public eye, publishing books, newspaper articles and pamphlets. He moved to California around 1915 and began publishing social critiques about the state, such as 100 Percent, The Story of a Patriot, The Goose Step, 0il and The Goslings.

Although born into a Democratic family, Sinclair left the party in his youth because he felt it had abandoned its original principles and had been sold to "corruptionists" and "the forces of Tammany Hall."33 He then allied himself with the Socialists. Throughout most of his career Sinclair had been actively identified with the Socialist Party; he was a Socialist candidate for Congress in 1906 and 1920 from New Jersey, for the United States Senate in 1922 from California, and for governor of California in 1926 and 1930. Sinclair made "the tenets of the party both a political philosophy and a religion" for thirty-two years up to the period of the EPIC movement. ${ }^{34}$ Yet in all his campaigns for office,

\footnotetext{
${ }^{33}$ Sinclair, I, Governor of California, pp. 1-2.

${ }^{34}$ Robert Glass Cleland, California in Our Time (New York:
} Alfred A. Knopf, 1947), p. 220 . 
Sinclair polled only a few thousand votes. After the death of Eugene Debs, Socialist Party leader, in 1926, Sinclair, for many years, provided both the philosophical and political leadership of the Socialist Party. Sinclair's decision to leave the Socialist Party was a difficult one. Sinclair's break from the party was the result of his dissatisfaction with conditions, party dissension and disorder, and of being "tired of losing... and even worse... being ignored by both major parties. 35 Recognizing he had little chance to win as a Socialist in 1934, Sinclair re-registered as a Denocrat on September 1, 1933 at the Beverly Hills

City Ha11. "Now that the party had been recaptured by Franklin D. Roosevelt," Sinclair asserted, he could once again join the Democrats. While still committed to the principles of Socialism, Sinclair claimed:

I am a Democrat by the same right that makes us Americans either Republicans or Democrats--I was born one. If by the name Democrat you mean an advocate of the right of the people to manage their own affairs, then I am still the Democrat I was born.

Sinclair further explained:

Fifty per cent of the people are going to vote a certain ticket because their grandfather voted that ticket. In order to get anywhere it is necessary to have a party which has grandfathers. ${ }^{36}$

Sinclair believed that he could revive "dormant Progressivism" through the Democratic Party, incorporating many Socialist planks in his EPIC plan. ${ }^{37}$

${ }^{35}$ Leon Harris, Upton Sinclair: American Rebel (New York: Crowel1, 1975), p. 297.

${ }^{36}$ Sinclair, I, Governor of California; pp. 1-6.

${ }^{37}$ Bernard Hyink, Leyon Brown, and Ernest Thacker, Politics and Government in California (New York: Thomas Y. Crowell Co., 1969), p. 67. 
While Sinclair hoped that a Socialist solution be adopted in California and the nation, he realized that, "Only from within one of America's two major political parties could the changes...essential for the country be effected." 38 Sinclair intended to "use an old party for a new job," that of promoting "production for use" to create a cooperative commonwealth. 39

Sinclair explained to Norman Thomas, leader of the American Socialist Party, why he left the Socialist ranks. Primarily, he believed that the doctrine and vocabulary of Socialism was removed from American life, asserting:

What we want and must have is a movement based upon Amexican conditions, and speaking the American language. Ours is not a working class country. Our workers act and speak and dress middle class... This depression has been just as hard on the middle class as on the workers, and they are looking for help and are ready to join anybody who shows them the way out. 40

Since he felt Socialism was a foreign movement and Americans did not have a "working class mentality", Sinclair believed the Socialist Party in America could never lead California, or the nation, out of the depression. ${ }^{41}$

Sinclair oulined his plan for California's salvation in a book

${ }^{38}$ Leon Harris, Upton Sinclair: American Rebel, p. 29.

${ }^{39}$ Sinclair, I, Governor of California, p. 1 .

${ }^{40}$ Schlesinger, Politics of Upheave1: The Age of Rooseve1t, p. 112 .

${ }^{41}$ Sinclair, I, Candidate for Governor: And How I Got Licked, p. 6. 
published in November 1933, entitled, I; Governor of California and How I Ended Poverty: A True Story of the Future. This book contained the basic principles of the EPIC plan, the organization of the movement, campaign strategy, Sinclair's goals as governor, and "victory" of the movement. The ideas espoused by Sinclair in his publication had been formulated as early as the 1920 Congressional race, when he ran as a Socialist. 42

The EPIC plan was a proposal to end unemployment. It promised to take the jobless off public and private charity and put them to work supplying their own needs. As the first plank of his political platform, he proposed giving the unemployed productive work to make themselves self-supporting. ${ }^{43}$ This was to be accomplished through a non-profit barter system backed by the credit power of the state. Idle factories and unused farm lands were to be leased or bought and developed into production for use colonies. In this way Californians could "End Poverty in California."

Sinclair believed that unemployment was the result of the profit system. With wealth being concentrated in the hands of few, workers. were unable to buy what they produced. The profit system was run by "insiders", "masters", "gamblers"--businessmen who put private profits above human values. ${ }^{44}$ Unemployment, he asserted, was a permanent condition in

42 Martin Zanger, "Upton Sinclair as California Socialist Candidate for Congress, 1920," Southern California Quarterly, LVI (Winter, 1974), 360.

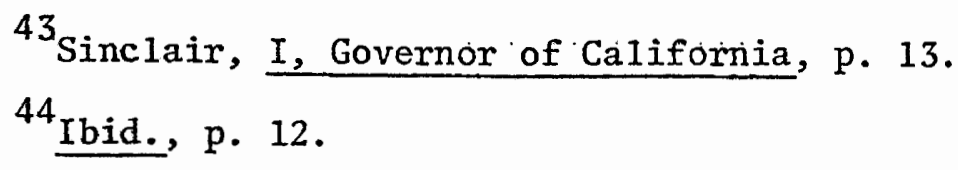


profit system societies. 45 "The only remedy which has any meaning," Sinclair maintained, is one whereby the "community as a whole comes into possession of the natural resources of the country and the means of producing useful goods." 46 In this way the economic system would be "made democratic through the Democratic political system." 47

Sinclair specified twelve principles in his EPIC plan which he described as the foundation of his program. While many of his EPIC goals were later modified or eliminated, Sinclair refused to compromise on these principles:

1. God created the natural wealth of the earth for the use of all men, not a few.

2. God created men to seek their own welfare, not that of masters.

3. Private ownership of tools, a basis of freedom when tools are simple, becomes a basis of enslavement when tools are complex.

4. Autocracy in industry cannot exist alongside democracy in government.

5. When some men live without working, other men are working without living.

6. The existence of luxury in the presence of poverty and destitution is contrary to good morals and sound public policy.

7. The present depression is one of abundance and not of scarcity.

8. The cause of the trouble is that a small class has the wealth while the rest have the debts.

9. It is contrary to common sense that men should starve because they have raised too much food.

45 R.D. Delmatier, Clarence McIntosh, and Earl Waters, Rumble of California Politics, 1848-1970 (New York: Wiley \& Sons, 1970), p. 273.

${ }^{46}$ Schlesinger, Politics of Upheave1: The Age of Rooseve1t, p. 111 .

${ }^{47}$ Delmatier, McIntosh, and Waters, Rumble of California Politics, 1848-1970, p. 91 . 
10. The destruction of food or other wealth, or the limitation of production, is economic insanity.

11. The remedy is to give the workers access to the means of production, and let them produce for themselves, not for others.

12. This change can be brought about by action of a majority of the people, and that is the American way. 48

These basic principles, therefore, formed the core of Sinclair's EPIC program and his general campaign theory.

The EPIC plan proposed to establish three new major state divisions. The California Authority for Land (CAL) was to be established through the California Land Colonies Act. This action called for the right of eminent domain to condemn land for the purpose of cooperative colonies. CAL also was empowered to buy land sold for taxes and under foreclosure proceedings. It was empowered to establish land colonies for the unemployed throughout the state and was to assist the members in running them.

Working with CAL, the California Authority for Production (CAP), established through the California Authority Production Act, was to acquire unused factories in conjunction. with the land authority and allow workers to put them to productive use to provide the basic necessities required for themselves and the land colonies. The intent of CAP was to create an autonomous economic system within the existing capitalist structure.

A third major proposal was to be the California Money Act which proposed the establishment of the California Authority for Money (CAM).

${ }^{48}$ Sinclair, I, Governor of Califormia, p. 10. 
This agency was empowered to issue script for the purchase of CAL and CAP products (agricultura1 and manufactured goods). CAM also had the power to issue up to $\$ 300,000,000$ worth of bonds to finance these agencies. $^{49}$ It was empowered to issue script to be paid to workers and used in the exchange of products within the system. The script to be issued to the workers by the state represented goods acquired by the system or services rendered to the system.

Later in the campaign Sinclair modified CAM. EPIC ranks acknow1edged that it was unconstitutional for a state agency, like CAM, to issue script. This power remained the exclusive right of the federal government. Sinclair therefore modified CAM and renamed it the California Authority for Barter ( $C A B)$. $C A B$ was not able to issue script but was authorized to arrange for barter arrangements between the state, the land colonies, and cooperative factories. When referring to state money, Sinclair suggested the use of terms like "warehouse receipts" and "certificates of service rendered."

In state factories, workers would be free to work as many hours as they desired. The more hours worked, the more one earned. Machines could be used at seven hour shifts, three shifts per day. Sinclair declared that statistics indicated there were more than 10,000 factories in California which worked on an average at forty percent capacity, while sixteen percent were entirely idle. 50

49 Ibid., pp. $21-22$.
50 Sinclair, I, Candidate for Governor: And How I Got Licked, p. 13. 
As long as the factories were in debt to the state, the state was to manage them. Once the workers paid off the bonds, they were to become free citizens of industry; living in a self-governing community, choosing their own managers and officials.

In addition, the EPIC plan called for a pension of fifty dollars per month for persons over sixty years of age, blind persons, and widowed mothers. Sinclair promised that, "every man; woman, and child would have the equivalent of $\$ 5,000$ per year." 51

The EPIC plan was to be initiated and underwritten by the state until the cooperatives achieved autonomy. To finance this plan the sales tax would be repealed and replaced by a graduated income tax s.tarting with all incomes. over $\$ 5,000$ and rising to a thirty percent levy on incomes over $\$ 50,000$; inheritance, utility and corporation taxes were to be raised and a ten percent tax levied on all unimproved and uncultivated land. It also proposed that new constitutional amendments be passed revising the state tax code so to exempt from taxation homes assessed at less than $\$ 3,000 .^{52}$

Sinclair estimated that EPIC could be started for "a very small sum of cash, perhaps five or ten million dollars," and that in less than a year the state would be able to eliminate all state obligations. ${ }^{53} \mathrm{He}$ also maintained that the proposed income tax, which would be levied as

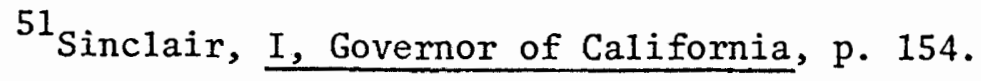

52 Ibid., p. 23.

53 Sinclair, I, Candidate for Governor: And How I Got Licked, p. 16. 
soon as he became governor, would bring in between $\$ 35,000,000$ and $\$ 40,000,000$ per year. 54

EPIC supporters claimed that the strength of their program was two fold. First, the EPIC plan would not intensify class antagonism and strife. According to Sinclair class antagonism had been increasing in the state, and nation, for years; the adoption of EPIC would slow this trend and eventually eliminate all strife. EPIC also proposed to gradually alter the business and profit structure which Sinclair believed was rapidly disintegrating. 55 Secondly, the EPIC plan would enable thousands of unemployed to find productive and meaningful work, which would allow them to become "self-supporting and regain their self-respect." Sinclair asserted that EPIC would restore "useful, self-reliant citizenship to hundreds of thousands of human beings." 56

While Sinclair had had the idea of establishing land colonies as early as 1907, he had put together the EPIC plan in just a few weeks. The plan was the focal point of the campaign and, because, of this it was under constant attack by Sinclair's opponents. Thus, as the campaign progressed, parts of the EPIC plan were modified in an attempt to obtain the support of the voters and unify the Democratic Party.

Sinclair claimed that his original EPIC plan had been "submitted to a number of experts for criticism as to its economic, legal and

\footnotetext{
${ }^{54}$ Sinclair, Immediate EPIC, p. 24.

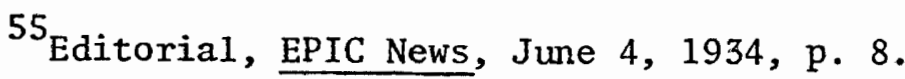

${ }^{56}$ EPIC News, September 3, 1934, p. 8.
} 
political soundness and the program revised to meet objections which seemed well based." ${ }^{57}$ The valid criticisms of these experts were used by Upton Sinclair in modifying his EPIC program. However, when Sinclair was asked for the names of the "fifty...most qualified thinkers" he could not remember any details. 58

To intitiate the EPIC plan, Sinclair registered as a Democrat, and entered his new party's primary race as a candidate for governor. Sinclair's book, I, Governor of California and How I Ended Poverty marked the beginning of his bid for state office. Sinclair campaigned actively throughout the next ten months.

The End Poverty League was formed to disseminate information to all EPIC followers. The League, the official organization of the EPIC movement, was incorporated as a non-profit association with headquarters in Los Angeles. ${ }^{59}$ A news sheet, the EPIC News, was published and became the official news organ of the party during the campaign. The purpose of this newspaper was to counteract the propaganda which branded Sinclair "a communist, anarchist, and atheist..."60 EPIC News was distributed by League at five cents a copy and achieved a circulation of more than two million copies. ${ }^{61}$

${ }^{57}$ Sinclair, I, Governor of. California, p. 23.

${ }^{58}$ Sinclair, I, Candidate for Governor: And How I Got Licked, p. 16.

59 Ibid., p. 20.

${ }^{60}$ Judson Grenier, "Upton Sinclair: The Road to California," Southern California Quarterly, LVI (winter, 1974), 333.

${ }^{61}$ EPIC NewS, August $28,1934, p .1$. 
In February 1934, Sinclair turned over the publication of I, Governor of California and How I Ended Poverty to the EPIC League. For the remainder of the campaign the League published the book, sold it for twenty cents per copy, and used the funds to help finance the campaign. ${ }^{62}$ As his campaign manager, Sinclair selected Richard Otto. Sinclair's choice, however, proved to be a mistake as Otto's lack of political experience proved a handicap to the campaign. 63

The EPIC campaign workers were largely inexperienced, even though many had had previous experience in radical and reformist groups, particularly the Socialist Party. The EPIC movement obtained the majority of its support from revived Bellamy Clubs, Technocracy organizations, and the Utopian Society of America. These organizations advocated, 1ike EPIC, production for use and the abolition of the profit system. 64

In the primary campaign, Sinclair's major opponents were George Creel, west coast administrator of the National Recovery Administration, and Justus Warde11, a longtime party leader from San Francisco. Creel had entered the race at the urging of Maurice Harrison, state committeeman from Northern California, and Thomas M. Storke, a Santa Barbara publisher. ${ }^{65}$ During the campaign Creel was endorsed and supported by

${ }^{62}$ Upton Sinclair, The Lie Factory Starts (Los Angeles: End Poverty League, 1934), p. 12 .

${ }^{63}$ Sinclair, The Autobiography of Upton Sinclair, p. 269.

${ }^{64}$ Delmatier, McIntosh, and Waters; Rumble of California Politics, 1848-1970, p. 274.

${ }^{65}$ George Cree1, Rebel at Large, Recollections of Fifty Crowded Years (New York: Putnam \& Sons, 1947), p. 280. 
Senator McAdoo. A fourth candidate was Milton K. Young, an associate of McAdoo. There were other minor candidates in the race but they had only local strength, receiving few votes.

In contrast to the Democratic primary, the Republican contest was non-eventful. Due to Governor Rolph's death in June 1934, Frank Merriam had become California's Acting-Governor. Using his advantage as the incumbent, Merriam did little active campaigning. His major opponents were the former Governor C.C. Young of Burlingame; Raymond L. Haight, a Los Angeles attorney who had been Commissioner of Corporations under Governor Rolph; and John Quinn, past commander of the American Legion and chairman of the Los Angeles City Board of Supervisors. Haight also registered and ran as a member of the Progressive Party and as a member of the Commonwealth Party. Haight's multiple party registration assured him a place on the November ballot. 66

The primary election was held on August 28 and Sinclair received an unprecedented victory. The final totals were Sinclair, 436,220; Cree1, 288,106; Warde11, 48,965; and Young, 41,609. There was a scattering of votes for the other minor candidates. ${ }^{67}$ Sinclair, however, polled more votes than all his opponents combined and proved himself a strong political contender.

On the Republican ticket Merriam had polled 346,329; C.C. Young,

${ }^{66}$ McWilliams, "Upton Sinclair and His EPIC," p. 4.

${ }^{67}$ Frank C. Jordan, comp., Statement of the Vote for the Primary Election (Sacramento, Calif.: State Printing Office, 1934), pp. 5-6. 
231,431; Quinn, 153,412; and Haight, 84,977. Haight, without opponents on either the Commonwealth or Progressive tickets, had also received, respectively 2,421 and 1,344 votes for a total primary vote of $88,742.68$

After the primary Sinclair modified six basic proposals of the original EPIC plan and, in September 1934, issued Immediate EPIC: The Final Statement of the Plan. First, as mentioned earlier, Sinclair renamed $C A M$ and created $C A B$ which would create a economic system based on the barter of goods rather than the use of money. Then, he acknowledged that his stock transfer tax would bring in, not $\$ 50,000,000$, but $\$ 2,000,000$ per year to the state treasury; in spite of this loss of projected income, he still maintained he would repeal the sales tax on the "necessities of life." 69 Sinclair then stated he would postpone the implementation of two other proposals which required amendments to the state constitution: a state tax upon unimproved land, and a plan to exempt from taxation all homes occupied by the owners with an assessed valuation of less than $\$ 3,000$. He also disassociated himself from the idea of pensions for the elderly, the disabled, and the widowed by simply "putting off this program until we see what the President does about federal social insurance laws." 70 After thinking about the purchase of land through bonds, Sinclair also decided to set the $\$ 300,000,000$ EPIC bond issue aside and "start upon a three year's rental basis and

${ }^{68}$ Ibid., pp. 5-6.

${ }^{69}$ Creel, Rebel at Large, Recollections of Fifty Crowded Years, p. 287.

${ }^{70}$ EPIC News, September 24, 1934, p. 5. 
prove our Plan." 71 In place of the bond issue, Sinclair proposed an emergency tax, called the "EPIC tax", upon public utilities and large individual corporations which would be levied to enable the state to pay its past debts and provide enough labor.

On September 20, a few days after the publication of Immediate EPIC, the Democratic Party met in Sacramento for its state convention. The main purpose of the convention was to formulate a platform. Refuting the rumor that the Democratic Party would repudiate the Sinclair plan at its convention, the delegates formally declared the EPIC plan as the official platform of the Democratic Party. The vote was 113 for the plan, four against.

Thus, the stage was set for the most bitterly contested campaign in California's history. The question was whether or not Sinclair could duplicate his primary success and convince Californians of the merits of his plan to end poverty. The opposition campaign fund to defeat Sinclair and EPIC was the greatest ever raised in the State of California. George H. Shoaf wrote to the American Guardian in Oklahoma City, "Without doubt this political contest has been the bitterest and possibly the most corrupt that has occured in our so-called American democracy."72

\footnotetext{
${ }^{71}$ Sinclair, Immediate EPIC, p. 25.

72 EPIC News, September 24, 1934, p. 1.
} 
CHAPTER III

CAMPAIGN STRATEGIES, AUGUST 28 THROUGH NOVEMBER 6, 1934

Without money, without administration experience, facing one of the most "amazing press conspiracies on record," Sinclair almost succeded in winning the gubernatorial race. "A depression nurtured faith" in the movement alone, enabled Sinclair to face the "worst smear campaign in California political history. 73 While the exact total spent by the Republican Party and state financial and industrial interests is not known, one California offical fixed $\$ 10,000,000$ as the total amount spent to elect Governor Merriam. ${ }^{74}$ Delmatier maintained forty years later, that the election was one of "the greatest smear campaigns ever waged in an American election."75 Time magazine pointed out that "no one in American political history, with the possible exception of William Jennings Bryan, had so horrified and outraged the vested interests and was more open to abuse than was Upton Sinclair."76 Not only did Sinclair oppose the Republican Party, but he also fought against many Democratic Party regulars, as well as the leaders of the Communist and Socialist

${ }^{73}$ Bean, California: An Interpretive History, p. 105.

${ }^{74}$ Harris, Leon, Upton Sinclair: American Rebel, p. 308.

${ }^{75}$ Delmatier, McIntosh, and Waters, Rumble of California Politics, 1848-1970, p. 239.

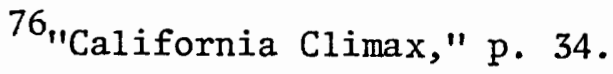


parties. 77

\section{EPIC STRATEGY}

From the outset, the EPIC movement faced financial and organizational difficulties. In November 1933, Sinclair and his future campaign manager, Richard Otto, a real estate subdivider, formed the End Poverty League. Sinclair's own home served as the first headquarters of the organization, but as the movement gained momentum the new headquarters relocated in a thirty-two room office building on Grand Avenue in Los Angeles. The office housed more than sixty-five full-time volunteers, the EPIC League, and the EPIC News staff. ${ }^{78}$

The EPIC forces employed several techniques to raise funds for the campaign. One such technique was the sale of four EPIC pamphlets written by Sinclair during the campaign. By November 6, 200,000 copies of the original pamphlet, I, Governor of California had been sold. The total sale of EPIC Answers, which told how various occupations would benefit from EPIC, reached 65,000 copies, while 50,000 copies of The Lie Factory

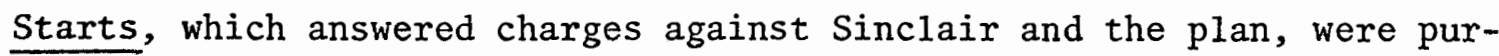
chased by the general public. The last EPIC pamphlet, Immediate EPIC, stated what Sinclair proposed to do during his first three months in office. Five thousand Californians bought this book between September and November 1934. This was a signficant number, considering the pamphlet was available for only six weeks prior to the November election.

${ }^{77}$ De1matier, McIntosh, and Waters, Rumble of Ca1ifornia Politics, 1848-1970, p. 387.

${ }^{78}$ EPIC NewS, August 28,1934, p. 1. 
In tota1, 435,000 pamphlets were sold. After the deduction of printing, distribution, and other costs, the EPIC forces claimed a profit of only $\$ 20,000 .^{79}$ Each of the pamphlets, except Immediate EPIC, sold for twenty cents; Immediate EPIC cost fifteen cents. Although the Los Angeles Times charged that Sinclair netted $\$ 250,000$ from the sale of EPIC pamphlets, Sinclair maintained that, as of May 16, 1934, he had collected only $\$ 1,500$ from his book sales. ${ }^{80}$

The primary EPIC fund raising technique was membership solicitation in the End Poverty League. A "substaining membership" cost a dollar, a "charter membership" five dollars, and a "life time membership" cost one hundred dollars. ${ }^{81}$ Statewide, by the end of 1933, there were 103 EPIC Clubs; by the August 28 primary there were nearly 1,000; and by the November election there were 2,000. Membership in these clubs ranged from twelve to 150 with over 100,000 volunteers in the state. ${ }^{82}$ The primary function of the EPIC Clubs was the distribution of EPIC NewS, the sale of EPIC pamphlets and the organization of precinct work.

The EPIC Clubs grew more rapidly in Southern California than in the rest of the state. About two-thirds of the clubs listed early in the campaign by the League were located in the southland. However, by the end of January 1934, there were enough EPIC organizations in Northern

${ }^{79}$ Sinclair, I, Candidate for Governor: And How I Got Licked, p. 30.

${ }^{80}$ Sinclair, The Lie Factory Starts, pp. 15-16.

${ }^{81}$ EPIC News, July 30, 1934 , p. 4.

82 Borough, Challenge of Sinclair's EPIC, p. 9. 
California to warrant the establishment of a San Francisco headquarters. $^{83}$

Campaign funds were also obtained through non-traditional political activities. Rummage sales were organized for the purpose of permitting "EPIC supporters to render assistance in the only way left to many of them, namely: the sacrifice of saleable articles." Revenue was also received from EPIC plays written by Sinclair and the sale of EPIC tire covers, ashtrays, pennants, and decals. Also through food and other merchandising at rodeos, auction sales, banquets, shows, etc., the EPIC forces made a "small profit on all of them" while putting "the ideas of the End Poverty campaign into the minds of the people of the state."84

Due to constant attacks and inaccurate reporting by the state's newspapers, the EPIC movement was forced to develop its own news organ. A survey of 192 daily and 423 weekly and semi-weekly newspapers showed that ninety-two percent of all papers endorsed Merriam, five percent supported Haight, and three percent had made no endorsement. ${ }^{85}$ No newspaper, with the exception of. EPIC News, officially endorsed Sinclair. The Elmer Belt Collection indicated that only three newspapers gave any favorable news coverage to the Sinclair candidacy. These included Manchester Boddy's Illustrated Daily News of Los Angeles, the San

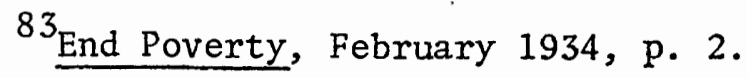

${ }^{84}$ EPIC News, June 11, 1934, p. 6; EPIC News, June 18, 1934, p. 7 ; E EIC News, Ju1y 23, p. 3 .

${ }^{85}$ Los Angeles Times, September 22, p. 3. 
Francisco News, and Turlock Tribune. ${ }^{86}$. However, none of the above papers printed editorials to support the candidacy of Sinclair. Then too, occasional news coverage was printed in the Los Angeles Evening News, the Modoc Times, and the Beverly Hills Script. Of all the newspapers in the state, the Los Angeles Times was the most.vicious in its coverage of Upton Sinclair and his EPIC movement. ${ }^{87}$

According to Kenneth Stewart, nine out of ten newspapers of the state supported either Merriam or Haight: The Ontario Weekly Herald, the only Democratic newspaper in San Bernadino County, after supporting Creel in the primaxy, announced on September 16, that it would support Governor Merriam. The Bakersfield Californian, published by Alfred Harre11, which had long supported state and national Democratic candidates, announced in an editorial that it could not support Sinclair as a Democrat since, in practice, he was not a Democrat: Also, the McClatchy Corporation, publishers of the Sacramento, Modesto, and Fresno Bee papers, gave their support to the candidacy of Raymond Haight. ${ }^{88}$ Toward the end of December 1933, the first issue of the campaign newspaper, End Poverty, appeared. End Poverty was published and owned by Edward Roberts, a former Hearst journalist, who had a contract with Sinclair covering the distribution and profits. After five months of

${ }^{86} \mathrm{Dr}$. E1mer Belt Collection on Upton Sinclair, Occidental College, Library.

${ }^{87}$ Kenneth Stewart, "Upton Sinclair and His EPIC Plan for California," Literary Digest, August 25, 1934, p. 10.

${ }^{88}$ Julian Nava, California: Five Centuries of Cultural Contests (Beverly Hills, Calif.: Glencoe Press, 1976), p. 342. 
dissatisfaction, the Sinclair organization took control of the newspaper, along with its debts, and renamed it the EPIC News. The new editor was Reuben Borough, previously of the Los Angeles Record. ${ }^{89}$

Borough proved to be a able manager; he achieved great success in increasing the circulation of EPIC News. Statewide distribution rose from 25,000 to more than $1,000,000$ under his leadership. The last edition prior to the general election circulated more than 2,000,000 papers. 90

To raise even more funds, Sinclair toured the state on speaking engagements. To the astonishment of old line politicians Sinclair was able to charge admission to political rallies. For example, in the closing days of the primary campaign, Sinclair addressed an audience of 10,000 in the San Francisco Civic Auditorium at which the audience paid twenty-five cents for admission to the main floor seats and ten cents for balcony seats. 91

Large mass meetings were held statewide, with the largest meetings held at the Shrine Auditorium in Los Angeles. Discussing Sinclair's speaking voice, Borough recalled:

Mr. Sinclair's oratory was declaimed in a high, then, and sometimes strained voice, to it was

${ }^{89}$ Donald Singer, "Upton Sinclair and the California Gubernatorial Campaign of 1934," Southern California Quarterly, LVI (Winter, 1974), 381 .

${ }^{90}$ Ibid.

${ }^{91}$ Schlesinger, Politics of Upheavel: The Age of Roosevelt, p. 123; EPIC News, June 24, 1934, p. 5. 
insistently, mercilessly repetitious. The speeches became like phonograph records which Sinclair could mun forward or backward on a movements notice. 92

The attendance at these mass meetings was tremendous. In the closing meeting on the eve of the November election, an overflow crowd of thousands at the Shrine Auditorium cheered for five minutes at the mention of Sinclair's name. Also on November 5, EPIC forces dramatized their support for Sinclair; hundreds participated in a torchlight parade from Angeles Temple in Los Angeles to Santa Monica and back. 93

Sinclair was not the only speaker espousing the EPIC program. EPIC supporters addressed sma11 community meetings throughout the state. The only instructions Sinclair gave to these speakers was to "stick to the text...Stick to the EPIC Plan and what it can do for Californians." The single recurring theme of the campaign was to end poverty in California through production for use. In the last days of the general campaign, the state headquarters of the Democratic Party alone booked more than 500 speakers month1y. 94

Sinclair did not limit his followers or himself to the speakers circuit alone; in April 1934 radio broadcasts became a regular part of the effort to propagandize EPIC. Sinclair broadcast weekly radio shows every Monday from 7:30 p.m. to 7:45 p.m. over CBS stations located in Los Angeles, San Francisco, San Diego, Santa Barbara, Fresno, Stockton,

${ }^{92}$ Singer, "Upton Sinclair and the California Gubernatorial Campaign of 1934," p. 381.

${ }^{93}$ EPIC News, November 5, 1934, p. 4.

94 Borough, Challenge of Sinclair's EPIC, p. 46; Carey McWilliams, "High Spots in the Campaign," New Republic, November 7, 1934, p. 356 . 
Sacramento, Kern, and Bakersfield. Other network affiliates transmitted EPIC programs in metropolitan areas like Lorig Beach, Los Angeles, Oakland, and San Francisco. From October 22, until November 6, 1934, daily broadcasts by nationally prominent individuals who were EPIC proponents were transmitted from the Philharmonic Auditorium over stations in Los Angeles and San Francisco. As the general election approached, the Democratic Party kept ten speakers continuously on the radio, doing more than 200 broadcasts. 95

Shortly after filing for office, Sinclair added to the EPIC strength by the formation of a ticket of candidates pledged to his program, the most important of which was the selection of lieutenant governor. Sinclair persuaded Sheridan Downey, a Sacramento attorney and law partner of Progressive state Senator Inman, to run with him. Downey was popular with the farmers of Northern California and was supported by the state Grange. Prior to May, Downey had been a candidate for the Democratic nomination for governor of California: In early May Downey held a press conference and announced that he was withdrawing from the race for the governorship of California and was aligning himself with the EPIC movement. The EPIC News reported that, "with the accession of Sheridan Downey...the movement to nominate Upton Sinclair... gains new strength throughout the state," citing Downey as having a "wide acquaintance among labor and liberal groups." 96

The EPIC strategy having been established, the Sinclair forces were

\section{End Poverty, Apri1. 1934, pp. 3-4; Carey McWilliams,} "High Spots in the Campaign," New Republic, November 7, 1934 , p. 356 .

96 EPIC News, May 28, 1934, p. 1. 
prepared to oppose all contenders in the California gubernatorial race. Unknown to Sinclair, the Republican Party and the financial and industrial interests of the state were preparing to launch what would be called the most vicious smear campaign in California history.

\section{CAMPAIGN STRATEGIES USED TO DEFEAT SINCLAIR}

Sinclair had written critical articles and books about almost every social institution in American life. The opposition capitalized on his detailed social critiques as a primary source of criticism, using quotations from his works to discredit Sinclair. The Republican State Central Committee hired the advertising firm of Lord and Thomas which, assisted by Clem Whitaker and Leone Baxter, retrieved material from Sinclair's numerous works which had been published over a period of thirty years. The Los Angeles Times pointed out Sinclair's vulnerability, stating that:

His eighteen years as a resident of California, Sinclair has spent in heaving extravagant vituperation upon everthing and everybody that have made Califormia what it is. 97

Utilizing Sinclair's complete works, the opposition focused their campaign on criticizing Sinclair's personality, politics, religion, and writings.

The opposition organized numerous "front groups" which circulated $6,000,000$ pamphlets and paid for 200,000 billboards throughout the state. 98 p. 495.

${ }^{97}$ Grenier, "Upton Sinclair: The Road to California," p. 333.

98 "The EPIC of Upton Sinclair," Nation, October 31, 1934, 
The most active of these "front groups" was the United for California League. The League quoted from a number of Sinclair's works in order to prove that the candidate was an atheist who advocated revolution, Communism, free love, and the scientific care of children. Ultimately the key issues used by the opposition which lead to Sinclair's defeat were: his communism and radicalism, the imminent flight of capital and industry, the influx of transients, combined with the use of Sinclair's works, the criticism of the EPIC plan, the split in the Democratic Party, the Tom Mooney case, and the vote fraud.

Communism and Radica1ism

Due to Sinclair's socialist background, his opponents charged that the EPIC movement attempted to "spread the mantle of Communism and radicalism." Senator Herbert of Illinois denounced Sinclair's candidacy as in line with the National Administration's move to the extreme left. In the August 30 issue of the San Francisco Chronicle, an editorial declared Sinclair as determined to bankrupt the business and farming interests of California and run the state in a Socialist manner. It also declared:

For the issue is no less than the very salvation of California: In that cause all who realize the danger must unite. The only efficient means of that united action is aggressive support of the candidacy of Governor Frank Merriam. It is a real crusade to which we are called, worthy of nothing less than the best and here it is in all of us.

The denunciation of Sinclair was not limited to Californians; on August 30 Senator Hastings of Delaware asserted, "California Democrats have elected a disciple of Karl Marx in preference to a real Democrat." The 
Santa Rosa Press-Democrat in a guest editorial of August 31 in the Chico Record asserted that "the vote in November must be a direct vote on the single issue of conservatism or communism... It is either Merriam or the inauguration of a Communist order." "To elect a Socialist governor in the State of California," asserted the San Jose News, "would be just one more step toward Communism and revolution." 99

Governor Merriam viewed "the fight against radicalism and socialism" as the single issue of the campaign. "The word, my friends, is Americanism. We recognize no other issue at this time." Merriam further denounced Sinclair as "an extreme Socialist."100

Ear1 Warren, district attorney of Alameda County and Republican State Central Committee chairman, also labeled the campaign race as "one against radicals and socialism." Through the defeat of Sinclair, Waxren maintained, the nation would be given notice "that California is a safe place for constitutional rights and liberties...We must fortify ourselves against a resolute purpose to overwhe1m California with Communism."101 The Republican platform, formulated on September 20, urged "an active and aggressive campaign of Americanism and liberalism against radicalism and the threat of communistic adventure in California." If successful EPIC, according to the Republican State Central Committee,

${ }^{99}$ San Francisco Chronicle, August 30,1934, p. 1; New York Times, August 30, 1934, p. 3; Chico Record, August 31, 1934, p. 1; San Jose News, July 7,1934, p. 4 . ${ }^{100}$ San Francisco Chronicle, September 30, 1934, p. 2. ${ }^{101}$ San Francisco Chronicle, October 29, 1934, p. 1. 
would "isolate this State and its people economically, politically, and socially from the remainder of the nation. "102

The Los Angeles Times used numerous techniques to spread the fear of radicalism to the people of California; the Times boasted of being "outstanding in fighting the Russianization of California." It used editorials, cartoons, and excerpts from Sinclair's speeches and writings to warn the Californians of the radical EPIC proposals. Through editorials, the Times repudiated the contention that Sinclair's program would not "Sovietize" California. The Times also encouraged the idea that Sinclair formulated his EPIC plan from the radical planks of the "Pittsburgh Plan of 1883." Not only did the Times' editorials and columns criticize Sinclair, but its news columns were slanted towards Merriam. Its political cartoons also showed the Times' political bias. For example, on September 5 the Times printed a cartoon which showed Sinclair with "Reds" standing on the sidelines looking on at the campaign activities. 103

On September 24 the Times began to publish its series of "black boxes", which were usually located on the front page and outlined in black. The boxes were one of the most damaging techniques used against Sinclair by the newspaper. Under bold headings in heavy type, supposedly authentic quotations of Sinclair's views were cited on such topics as "Sinclair on Violence", "Sinclair on Soviet Russia", etc. The most frequently cited works were Sinclair's The Goslings, The Industrial

\section{${ }^{102}$ San Francisco Chronicle, September 21, 1934, p. 1. \\ ${ }^{103}$ Los Angeles Times, November 3, 1934, p. 5; Editorial,} Los Angeles Times, September 8, 1934, Pt. II, p. 4. 
Republic, and The Profits of Religion. ${ }^{104}$

The San Francisco Chronicle was also harsh on Sinclair's socialist background, although not as vicious as the Los Angeles Times, in its editorial policy and news coverage. It did use, to some degree, the same type of front page editorials, biased political cartoons and slanted news columns. Sinclair was usually referred to in news columns as "the erstwhile Socialist" or the "Socialist masquerading as a Democrat" by the paper's political reporter, Earl Behrens. In the September 28 edition, Behrens reported that a nationwide advertising campaign was taking place to create a "slush" fund for Sinclair. Behrens noted that advertisements had been placed in such publications as Nation and New Republic and were signed by such "prominent radicals" as Clarence Darrow, Oswald Garrison Villard, Theodore Dreiser and Margaret Sanger. In general the paper viewed the gubernatorial race in the following way: "On one side, Socialism, offered under a counterfeit Democratic label. On the other side is progressive liberalism, presented by the Republican convention."105 The Chronicle also attacked Sinclair through its own comic strip series entitled, "Hon. Uptown Eclair." Written in pseudo-Japanese dialect, it featured Ineeda Moto, who corresponded with his cousin in Honolulu about Sinclair and EPIC. In describing Sinclair's past affiliation with the Socialist Party, Moto said, "Sochilisticke parti have negleck the

$$
104
$$

Los Angeles Times, September 24, 1934, Pt. I, p. 1.

${ }^{105}$ San Francisco Chronicle, September 7, 1934, p. 7; San Francisco Chronicle, September 28, 1934, p. 1; San Francisco Chronic1e, September 22, 1934, p. 1 . 
middle class: so jump on Democrack circus wagon (sic)."106

State newspapers were not alone in their attacks upon Sinclair. Political organizations such as the Veteran's Non-Partisan League of Northern California, United for California League, and the California League Against Sinclairism, distributed pamphlets which accused Sinclair of being a Communist. These organizations viewed Sinclair as a "Communist agitator...active official of the Communist organization," and a "Communist writer." Groups such as the Save Our State League published newspapers and pamphlets depicting Sinclair with such symbolic emblems as the hammer and sickle.

\section{Flight of Capital and Industry}

The flight of capital from California, which was reflected in declining prices for California securities and state, county, and city bonds, was attributed to Sinclair's candidacy. By September 7 it was reported that as a result of the uncertainty of Eastern investors in the California market, state municipa1 stocks and bonds were being sold at one to two points below their value. It was reported that further investments were being withheld until the November 6 election, with the Eastern establishment maintaining a "wait and see" attitude. By October 3 the Los Angeles Times reported that representative utility bonds and preferred stocks had dropped from five to ten points on an average. Moreover, B1yth and Co., a San Francisco stock brokerage house, issued a report which indicated that since the August 28 primary the liquidation of holdings in state, county, and city bonds, with a value of more than a 
billion and a quarter dollars, had decreased to fifty-two million dollars. Also according to the Los Angeles Times, by October 13 the Sinclair threat had caused state and municipal bonds to decline five percent since the August primary and that securities of private corporations had also depreciated substantially. ${ }^{107}$

Information concerning the financial security of the state varied. The Fresno Bee, in its October 6 edition, reported a San Francisco News survey indicating that a nineteen percent drop had occured in prices of California stocks. Yet the New York stock market, Dow Jones, indicated a drop of only four percent for the same period. Sinclair reacted to the situation on October 4 in the Chico Record, asserting that the flight of capital scare was being deliberately maneuvered by his political enemies in an effort to discredit his candidacy. 108

The San Francisco Chronicle used a series of cartoons with short articles, using quotations from Sinclair's writings, to show that EPIC would ruin not only the business and financial interests of the state, but would also bring poverty to those workers who were still employed. Each day the Chronicle would run a different cartoon such as a parodied donkey with wings called "The Bird of Paradise." Also, every cartoon used a variation of EPIC's initials to attack Sinclair, like "Empty Promises in California" and "Enterprises Perish in California."109

${ }^{107}$ Los Angeles Times, September 7, 1934, Pt. I, p. 16;

New York Times, October 31,1934, p. 1 .

${ }^{108}$ Fresno Bee, October 6, 1934, p. 3; Chico Record, October 4, 1934, p. 1 .

${ }^{109}$ San Francisco Chronicle, October 20, 1934, p. 10;

San Francisco Chronicle, October 6, 1934, Pt. I, p. 1. 
Many businesses throughout the state threatened to leave California if Sinclair was elected governor. The most vocal of these was the motion picture industry. Led by Louis B. Mayer, president of MetroGoldwyn-Mayer and Republican state committee vice-chairman, the film industry attempted to defeat Sinclair. The leaders' first strategy was to declare that they would move the entire motion picture industry out of California if Sinclair was elected. Relocation announcements began on October 16 with Cecil B. DeMille, a Hollywood director, stating his intentions. Then Harry Cohn, president of Columbia Motion Picture Studios, declared that he would move to the East coast should Sinclair be elected. From Florida, Joseph M. Schenck, president of Twentieth Century Fox Studios, reiterated the views of DeMille and Cohn and declared in Miami: "If Florida is on the alert it will benefit to the extent of $\$ 150,000,000$ a year on the film industry if Sinclair is elected." Throughout the campaign this threat to flee from California was impressed upon the voters. The San Francisco Chronicle illustrated the flight of industry with a cartoon entitled, "End Pictures in California. Shall We Let Them Go?" However Carl Laemmle, president of Universal Studios, refused to follow the other industry leaders and declared that his studio would remain in California no matter who won the election. He stated, "I never have cared a rap who was or was not governor." 110

110 Los Angeles Times, October 16, 1934, Pt. I, p. 5; Chico Record, September 18, 1934, p. 5; Leo Rosten, Hollywood: The Movie Colony, the Movie Makers (New York: Harcourt, Brace \& Co., 1941), p. 135; San Francisco Chronicle, October 8, 1934, p. 10; EPIC News, September 24, 1934, p. 1 . 
Other businesses within the financial and industrial community also threatened to leave Califormia. C.H. Fennell in the Los Angeles Times on October 3 announced that Chrysler Motors in California would curtail operation in the state as rapidly as possible if Sinclair was elected governor. In Los Angeles, real estate agents formed a non-partisan group to defeat Sinclair. The president of this group, W.J. Barr, urged its members to:

...go out and sell Americanism for the next
60 days in this State. This is the most
important business any real estate man or
property owner can attend to between now and
election day. Our business as well as our
state and its constitution is at stake. 111

According to Deacon Colburn, manager of S.W. Investment Co., real estate sales in Los Angeles were dependent upon the November election. He reported that reality companies had buyers but these buyers desired to wait until after the election, in order to insure the value of their investment. Insurance sales were supposedly affected by the Sinclair candidacy. Guy MacDonald of the San Francisco Chronicle reported dangers to policy holders that "approximately four million Californians were facing loss of equities should EPIC become operative."112 Also Ira B. Langdon, a Stockton attorney. who represented the farm interests and cooperatives, declared that Sinclair's intention was to destroy all property values in California and transfer ownership to the state as soon as the farmers had failed to survive. ${ }^{113}$

${ }^{111}$ Los Angeles Times, September 26, 1934, Pt. I, p. 4. 112 San Francisco Chronicle, October 22, 1934, p. 9. ${ }^{113}$ Chico Record, October 19, p. 8. 
Industries used various tactics to influence stock holders and employees to: elect Merriam. The Standard Oil Company sent a letter to its stockholders which warned that the value of their stock and the business of the company were threatened by Sinclair. The letter declared that this was "not a political issue but a matter of business" and therefore the action was justified. ${ }^{114}$ The Pacific Mutual Life Insurance Company requested eight hundred employees to sign circulars recording them as opposed to Sinclair and in favor to Merriam. This request exempted Republicans. ${ }^{115}$ Turner Catledge of the New York Times reported that many large industrialists had notified their employees that their jobs would be eliminated if Sinclair won the election and initiated his EPIC program. 116

Influx of Transients

Associated with the flight of capital and industry was the influx of transients. Of the tactics employed by Sinclair's opposition, this was one of the most effective techniques used to defeat Sinclair. Attacks against Sinclair began in September after Sinclair delivered the following speech in New York:

If I am elected about one half of the unemployed in the whole country will climb aboard freight trains and head for California.

114 Letter, sent by the President of Standard Oil Co. to its stockholders, October 26,1934, University of California, Bancroft Library, R.V. Taggert Scrapbook of Republican Campaign Literature for the 1934 California Gubernatorial Campaign.

115 Commonwealth Club of California, The Population of California (San Francisco: Parker Printing Co., 1946), p. 54. ${ }^{116}$ New York Times, October 30,1934, p. 8. 
There is no telling how many will come and no way to keep them from coming. 117

Newspapers throughout the state and nation repeatedly used cartoons to depict the "rush of bums and reds to California" in freight cars and in other modes of transportation. The title of the song, "California, Here I Come," was used to title many of the cartoons with slight alteration, "California, Here We Come." The Los Angeles Times on November 1 printed a series of cartoons from newspapers across the nation, showing Californians what the people of the nation thought of the local election. Cartoons appeared from the Newark Evening News, Chicago Daily News, Saturday Evening Post, Tampa Morning Tribune, and Greenfield, Massachuset Daily Recorder Gazatte. All showed the onrush of "bums" to California. As a result of the motion picture industry's fear of Sinclair, it organized "vigilante" political groups for Merriam. The producers' raised a campaign fund for Merriam of one-half million dollars, partly by requiring their employees to contribute one day's wage. The money was then used to produce "fabricated newsreels" which depicted Sinclair as a "wìldman" who wanted to "divest property owners of their holdings, institute communism and promote an agnostic campaign against religion."118 Only a small number of Hollywood actors and the Screen Writer's Guild opposed the industry actions. While most actors and writers went along with this "request", some rebelled against the "Merriam tax." Jean Harlow and James Cagney led an.actors' revolt, while Gene Fowler organized

117 Los Angeles Times, September 28,1934 , Pt. I, p. 1.

${ }^{118}$ Bob Barger, "Raymond L. Haight and the Commonwealth Progressive Campaign of 1934," California Historical Society Quarterly, XLIII (September, 1964), 226. 
a writer's committee for Sinclair. 119 Such actors as Charlie Chaplin, Dorothy Parker, Nunnally Johnson and Morxie Ryskind actively fought against the industry's political demands. Also, a court action was begun in an effort to stop the coercion, but EPIC did not have the money or manpower to devote to the case. As a result, the case never came to trial.

The producers' main barrage against Sinclair consisted of a series of "fabricated" newsreels. Motion pictures were taken of groups of "disreputable vagrants" in the act of crossing "the California border." The pictures were actually taken on the streets of Los Angeles by cameramen from a major studio; the "vagrants" were actors on studio payrol1s, dressed in false whiskers and dirty clothes. These "newsreels" were spread across the screens of leading theaters, owned by the studios, in every city in the state. 120

Although the motion picture industry's major statewide impact on the voters was through the use of newsreels; locally the industry a1so influenced voters through the use of "faked photographs.". These photographs perpetuated the fear, developed by the opposition, that if Sinclair was elected the state would be overrun by an influx of unemployed migrants. The New York Times reported that the Los Angeles Times requested and used these photographs. The Times printed the "stills" with captions like "Typical Box-Car Tourist," which described a typical scene in California of "thousands of indigents" pouring "into California

119 Leo Rosten, Hollywood: The Movie Colony, the Movie

Makers (New York: Harcourt, Brace \& Co., 1941), p. 136.

${ }^{120}$ Sinclair, I, Governor of California, pp. 136-37. 
lured by the rosy promises of Upton Sinclair..." The photograph, while extremely realistic, was identified as a still picture from a movie entitled the "Wild Boys of the Road," which featured famous actors like Frankie Darrow and Dorothy Wilson. ${ }^{121}$

The movie industry's involvement in local politics through such newspapers as the Los Angeles Times was never confirmed. According to Earl Behrens of the San Francisco Chronicle the California Crusaders, an anti-Sinclair group, played a major role in the "fabrication" of photographs. Thomas Ellsworth, Executive Secretary of the organization, stated the purpose of the Crusaders as "to have no political ambition and no candidate," but to help provide good government. The California Crusaders criticized Sinclair through radio broadcasts which warned the public about the large number of transients California would have to support if Sinclair won and EPIC was initiated. Ellsworth also denied that the "pictures furnished for publication... of the bums and indignants into California" were fakes. "All the pictures were of bonafide transients from the incoming hordes of unemployed." To further support the authenticity of the photographs, Ellsworth posted $\$ 100$ as an open challenge to anyone who could "prove a particle of fact" in the charges against the Crusaders. 122

Irving Thalberg, production chief at Metro-Goldwyn Mayer,

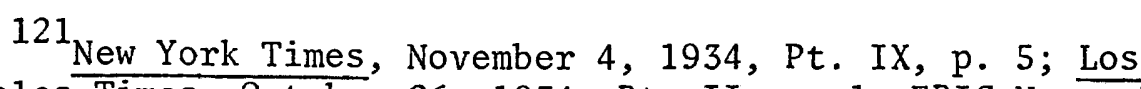
Angeles Times, October 26, 1934, Pt. II, p. 1; EPIC News, November 5, 1934, p. 3 .

122 New York Times, November 4, 1934, Pt. IV, p. 5; San Francisco Chronicle, October 15, 1934, p. 24; Los Angeles Herald and Express, October 30,1934, p. A13. 
invented a character called the "Inquiring Reporter" who supposedly traveled around the state interviewing "typical" Californians, soliciting their reactions to the campaign..$^{123}$ of all the techniques used to defeat Sinclair by the movie industry, the "Inquiring Reporter" had the greatest impact. In one of the interviews the "Inquiring Reporter" asks an elderly lady in a rocking chair. who she is going to vote for, which she replied Merriam, when asked why she is going to vote for Merriam the lady states, "Because I want to save my little home. It's all I have left in this world." In another interview, an unkempt man with "brist1ing Russian wiskers" with a thick Russian accent declares Sinclair as his candidate because, "...his system vorked vell in Russia, vy can't it vok here (sic). "124

Not until October 26 did the Sinclair forces realize the devastating effect that the "fabricated" newsreels had had on the candidacy of Sinclair. A spokesman from EPIC headquarters charged that there was a conspiracy on part of prominent motion picture leaders to defeat Sinclair. Richard Otto charged that the conspiracy was engineered by C.C. Pettijohn of New York, general counsel for the Motion Picture Producers and Distributors Association, Inc., with the cooperation of Louis B. Mayer, president of Metro-Goldwyn Mayer, and William Hayes, president of the Motion Pictures Producers' Association. ${ }^{125}$ While the EPIC forces requested a federal congressional investigation of the industry and their media

$123_{\text {Rosten, Hollywood: The Movie Colony; the Movie }}$ Makers; p. 137.

${ }^{124}$ New York Times, November 4, 1934, Pt. IX, p. 5. ${ }^{125}$ Los Angè es Times, October 26, 1934, p. 7. 
activities, their efforts were ineffective. ${ }^{126}$

The impact of the movie industry in the campaign was tremendous. The campaign slush fund which the producers raised, "The Inquiring Reporter" and its effect on the middle class vote, and the aid rendered to the Merriam organization during the campaign were all important factors in Sinclair's defeat. Most of all, the nation witnessed the movie industry's ability to influence public opinion and mold voters' ideas.

Throughout the state newspapers reported large movements of people into California. Russell Bevans, Registrar of the State Division of Motor Vehicles, reported that 61,528 more persons entered California from June through September 1934, than during the same period in 1933. The Chico Record reported on October 25, that some 300 men and twelve women had passed through Chico on October 24, on freight trains from Oregon. These transients carried placards which read: "We're going down to meet Sinclair where we will have plenty to eat." According to the Los Angeles Times, many of the transients, upon reaching Southern California, were sent to jail by the courts for evading railway fees. It was reported that through such actions the state was attempting to discourage further migration. ${ }^{127}$

In late September Bevans reported that transients were arriving by automobiles into California at a daily average of 100 persons. In

${ }^{126}$ San Francisco Chronicle, October 29, 1934, p. 4.

${ }^{127}$ Los Angeles Times, October 19, 1934, Pt. I, p. 1; Chico Record, October 24, 1934, p. 3; Los Angeles Times, October 26, 1934, Pt. II, p. I. 
October Theodore J. Roche, director of the State Division of Motor Vehicles, announced that there had been an increase of 8,183 auto permits over the same period in 1933. The October 31 issue of the Chico Record reported that according to Florence Warner, relief administrator for Arizona, 30,000 unemployed traveled through Arizona to California to date. On October 19 the Fresno Bee reported that more than 218,000, three times the size of Fresno, had arrived since the August primary. In August further reports were issued by the Division of Motor Vehicles. The division reported that the following numbers entered the state from various checking stations: Blythe, 2,911 cars with 8,170 passengers; Clam Beach, 3,044 cars with 9,040 passengers; at Yuma, 2,198 cars with 9,006 passengers; at Truckee, 2,373 cars with 7,306 passengers; and at Yermo, 3,574 cars with 10,662 passengers. The Los Angeles Times also reported that 22,523 persons were in transient camps throughout the state in July, while 21,974 lived in the camps in August. ${ }^{128}$

The San Francisco Chronicle commented on the influx of transients through a cartoon series which depicted California as the "POOR HOUSE of the WORLD." The Chronicle cartoons featured further name plays on the EPIC slogan declaring that EPIC stood for "Every Pauper is Coming." Interviews by Earle Ennis, a staff writer, reported that transients were attempting to reach the San Joaquin Valley with no gasoline and no money, inspired by Sinclair's promise that "everybody could get a job

${ }^{128}$ San Francisco Chronicle, October 4, 1934, p. 1; Chico Record, October 31, 1934, p. 2; Fresno Bee, October 19, 1934 , p. 1; Los Angeles Times, September 20, 1934, Pt. I, p. 5. 
in California." 129

Use of Sinclair's Words

Another effective method used by the opposition to defeat Sinclair was the use of his books, newspaper articles and pamphlets as a source of criticism. Among the widely quoted books of Sinclair were The Jungle, an exposé of the meatpacking industry; Brass Check, a study of American journalism and newspaper practices; Goose Step, a study of American education and education practices; Profits of Religion, a discussion of Sinclair's religious ideas; Letters to Judd, written about the failure of the capitalist system; $\underline{0 i l}$, an exposé of oil scandals in Southern California; and, The Goslings, a further analysis of American education.

Quotations by Sinclair on religion and churches were used as the primary source for discrediting his candidacy. The opposition used quotations out of context and misquotations from a book Sinclair wrote in 1918 entitled, The Profits of Religion. The book espoused Sinclair's belief that religion had perverted the Christianity of Jesus. Sinclair accused the churches of supporting the established class structure which perpetuated poverty and human suffering. In addition Sinclair antagonized churches with such labels as "The Church of the Good Society" (Episcopa1), "The Church of the Servant Girls" (Roman Catholic), and "The Church of Quacks" (Latter-Day Saints, Seventh Day Adventists and Christian Scientists). ${ }^{130}$ In evaluating the causes of his defeat,

${ }^{129}$ San Francisco Chronicle, September 28, 1934, p. 1; San Francisco Chronicle, October 16, 1934, p. 7.

${ }^{130}$ Upton Sinclair, The Profits of Religion: 'An Essay in Economic Interpretation (Pasadena: By the Author, 1918), pp. 913. "(Hereinafter referred to as The Profits of Religion.)" 
Sinclair later stated that he regarded this book as the most important single factor. ${ }^{131}$

The newspapers also criticized Sinclair's religious philosophy, denouncing him as an "atheist". and "defiler of religion". The Los Angeles Times used its "black boxes" to publish quotations on religion. The boxes were given such headlines as: "Sinclair Parodies Christ", "Sinclair on Catholics", "Sinclair on Methodists", "Sinclair on Clergy", and "Sinclair on the Church". In addition, the Times' "black boxes" were reprinted and used as campaign handbills. On October 21 the Times published a lengthly list of abbreviated quotations of Sinclair's, which were supposedly authentic, a few of which read: "Religion: amighty fortress of graft", "Baptists: hypocrites...full of uncleanliness and inequity", and "Christianity: the chief of the enemies of social progress". Other papers such as the San Francisco Chronicle, Fresno Bee, and Chico Record quoted Sinclair's writings on religion but did not devote the space nor importance to it that the Times provided.

A large number of campaign materials, handbills, and pamphlets focused on Sinclair's religious views and all used his Profits of Religion to substantiate their charges. The United for California League issued pamphlets titled: "Upton Sinclair Discusses the Mormon Church", "Upton Sinclair's Opinion of Christian Science", "Upton Sinclair on the Catholic Church", "Upton Sinclair's Attitude on Christianity", and "Upton Sinclair, Defiler of All Churches and All Christian Institutions." The Women's Non-Partisan Committee--Merriam for Governor also used the pamphlet

${ }^{131}$ Upton Sinclair, "The Future of EPIC," Nation, November 28, 1934 , p. 616. 
"Upton Sinclair, Defiler of All Churches and All Christian Institutions", in one issue of a publication entitled, "A Challenge to Church Women". Then too, the Democratic Merriam for Governor Campaign Committee, led by such prominent Democrats as J. Pendleton Wilson and Matt I. Sullivan, issued a pamphlet entitled: "Democrats for Merriam Campaign Committee Submits the Following for Careful Consideration of the Voters of Califormia". This, too, contained quotations from the Profits of Religion. The Catholic Division of the Merriam for Governor League published in its Civic News Support a letter from the Catholic leader Frank J. Barry, which urged his fellow Catholics to oppose Sinclair because of Sinclair's anti-Catholic and religious attitude. The California League Against Sinclairism published a pamphlet, "Upton Sinclair Attacks All Churches". The League Against Religious Intolerance also issued a pamphlet, "So the People May Know--That Upton Sinclair is Opposed to All Churches, The Unmasking of Upton Sinclair", which was published by Martin Luther Thomas, a minister of the Methodist Federalist Church. Also, the Fresno Shopping Guide, on Thursday October 18, contained a full page ad for Governor Merriam quoting Sinclair on religion. ${ }^{132}$

Ministers throughout the state also became aroused by the Sinclair threat and vocalized their views through sermons, on the radio, and speeches at conventions. On September 14, Dr. Hugh K. Walker, minister of the First Presbyterian Church in Los Angeles, Reverend W. Grayson Birch, pastor of the Cockran Avenue Baptist Church, Reverend Merle E.

${ }^{132}$ Pamphlets, collected between August 28 and November 6, 1934, University of California, Bancroft Library, R.V. Taggert Scrapbook of Republican Campaign Literature for the 1934 California Gubernatorial Campaign. 
Fish, pastor of Pico Heights Christian Church, and Dr. J. George Brown, pastor of the Hollywood Lutheran Church, announced their support for Governor Merriam, declaring that he was a Christian and a statesman. They stated that because Sinclair was a radical and against organized religion, his election would signal the decline of religion in California. 133

On September 20, Reverend Everett B. Parrott, before a Los Angeles tent revival meeting of 3,500 , branded Sinclair as an "enemy of the social and Christian progress." In addition, Parrott urged all religious groups in Los Angeles to defeat Sinclair. A similar appeal was made on September 25, by the Los Angeles Presbytery of the Presbyterian Church, comprising of 110 churches, which endorsed the candidacy of Governor Merriam. 134

On October 8 , the Los Angeles Times printed a radio address given by Dr. Roy L. Smith, pastor of the First Methodist Episcopal Church. Dr. Smith declared that Sinclair had created bitterness and opposition toward the church. He also stated that Sinclair was responsible for thousands of "sincere, far-visioned and conscientious Christian people to come under an unjust and indiscriminating indictment."135

Sinclair was endorsed in October by the Southern California Methodist Preachers' Association, having been exonerated of the charges of being an atheist and against all churches. As a result of the

${ }^{133}$ Los Angeles Times, September 15, 1934, Pt. II, p. 1. ${ }^{134}$ Los Angeles Times, September 21, 1934, p. 3; Los Angeles Times, September 26, 1934, Pt. I, p. 6 .

${ }^{135}$ Los Angeles Times, October 8, 1934, p. 4. 
association's declaration, a group of twenty-six lay members of the official board of South Pasadena Methodist Episcopal Church adopted a resolution which declared that the published words of Sinclair had been overlooked when the association absolved Sinclair of all charges. Reverend J.C. McPheeters, a Methodist minister in San Francisco, agreed with the disenting lay members and continued to attack Sinclair's religious views. In both church and radio sermons McPheeters accused Sinclair of unfounded attacks on Christianity and organized religion. 136

By October many political and religious leaders and organizations had relinquished their support of Sinclair for Governor Merriam. On October 17, ministers of Taft, California signed a proposal authored by Dr. Clarence L. Wright, pastor of the First Presbyterian Church, which declared their opposition to Sinclair. Wright's resolution was unanimously supported by the ministers declaring, "The ministerial union...has gone on record as being directly opposed to Sinclair and to favor Merriam." Then too, the Los Angeles Times on October 29 reported that Reverend W.E. Edmonds, pastor of Glendale Presbyterian Church predicted that "no man could antagonize the forces of Christianity and be leader of a great state." H.J. Grant, president of the Mormon Church, also announced to a group of church leaders that he would not vote for a man "... who has ridiculed in print the Savior of the World." During this period the Democratic State Committee remained silent, attempting to minimize the effectiveness of the charges against Sinclair. Rather than fight for Sinclair's candidacy, Democratic leaders like John J. Barrett, ${ }^{136}$ Sacramento Bee, October 2, 1934, p. 2; San Francisco Chronicle, October 18, 1934, p. 10. 
suggested that the party platform be compromised further to make Sinclair appear less controversial. 137

As the election. neared, the religious turmoil came to a climax. The Allied Churchmen of Los Angeles coordinated their programs and held a rally at the Shrine Auditorium. The program featured a pageant entitled "America Adrift" or "The Enemy Within", and was directed by evangelist Aimee Semple McPherson; pastor of the Angelus Temple. The pageant traced the historical and religious development of the United States, citing the impact of Communism. It predicted that the forces of Americanism would triumph over the forces of Communism, and because so, Upton Sinclair would be defeated. Over 6,000 people attended this non-denominational crusade to defeat Sinclair. Major speakers included the Reverend Martin Luther Thomas who accused Sinclair of defiling everthing he had ever touched. Bishop Edward Locke first emphasized that the church was non-partisan and then condemned Sinclair for his blasphemy. A Jewish leader, David Tannenbaum, and a Catholic layman, Joseph Scott, also spoke against Sinclair and his "Russian schemes." 138

In an attempt to pacify the political and religious opposition and its charges, Sinclair announced that a 1934 revision of The Profits of Religion changed many aspects of his original 1918 publication. Sinclair maintained that since the publication of his earlier work, many of his religious views and his philosophy had changed. On November 2 , four days

${ }^{137}$ Bakersfield Californian, October 17, 1934, p. 9; Los Angeles Times, October 23, 1934, Pt. I, p. 16; Sän Francísco Chronicle, October 1, 1934, p. 9; San Francisco Chronicle, September 19, 1934, p. 4.

${ }^{138}$ Los Angeles Herald and Express, November 3, 1934, p. A5. 
before the general election, the Los Angeles Times announced that the new edition of The Profits of Religion was available and was identical to Sinclair's original book. Sinclair responded by inferring that the book was different unless revisions and corrections had not been made by the publisher.

Although the majority of quotations used from Sinclair's works centered on the issue of churches and religion, he was equally as vulnerable as the result of writings on other issues. The importance of his words has already been shown in previous pages in those charges accusing Sinclair of being a radical and being responsible for the transient movement to California. The Los Angeles Times, between September 25 and November 4, used its "black boxes" of quotations to embarrass Sinclair in many other areas. Quotations in each issue were presented from Sinclair's works on the American Legion, Boy Scouts, judges, bankers, politics, the public, patriotism, education and the Elks. On October 19 the Times printed a comprehensive list of abbreviated quotations, some of which were:

Motion Picture Industry and Theaters: Honey pots which gather the feminine beauty and youthful charm of the country for the convenience of rich men's lust.

Public: The people do not have the intelligence to help themselves. We have not been able to teach our people as much sense as monkeys in the jungle. They do not know how to think.

Pasadena: A city supposed to be free and enlightened but in reality heavily burdened with churches.

Bankers: Legalized counterfeitors.

Colleges: Institutions of stupidity and corruption.

Disabled Veterans: A lot of good for nothing soldiers.

E1ks: Primitive lowbrows. 
Knights of Columbus: Voters on the side of ignorance and reaction.

Lawyers: Betrayers of mankind. 139

Through the publication of these quotations, the Times provided for antagonism against Sinclair from almost every segment of society in California.

The Times continued their attacks between October 2 and October 20, with the publication of a comic strip entitled, "Wynndebagge--the IPEGAC Candidate." Each strip paralled some phase of the California election campaign, depicting the escapades of Wynndebagge (Sinclair) and his campaign manager. In one strip, Wynndebagge moves from his Beverly Hills mansion to a cottage to appear as if a common man. At the same time the Times printed photographs in the newspaper which charged Sinclair with leaving his "palatial residence" for a modest Pasadena home to deceive the voters. Wynndebagge also urged bums and trouble makers to migrate to California and share in the benefits of his campaign. Wynndebagge ended his comic usefulness on October 20, at which time he was put into jail. The last strip showed Wynndebagge telling two rats in his cell that if they would follow his candidacy, he would get them out of jail as no rats belonged in jail. His manager, meanwhile, had hitched a ride out of the state with all the money accumulated during the campaign.

The San Francisco Chronicle summarized in two editorials the effectiveness of the use of Sinclair's words and writings to weaken his candidacy. The Chronicle maintained that it was Sinclair's own statements that destroyed his election chances. Regardless of his program, the opposition passim.

Los Angeles Times, September 25-November 4, 1934 , 
would not let Sinclair alter his past statements on such issues as religion, radicalism, and the threat of transients. It was impossible for Sinclair's "thirty years of words which poured from (his) pen" to be "erased or be removed." 140

\section{EPIC PIan}

The EPIC plan itself was an object of criticism and accusations during the election campaign. The San Francisco Chronicle denounced EPIC through a two week series of analytical articles by Professor T.J. Kreps of Stanford University entitled, "The Economic Falsehoods and Fallacies of the EPIC Plan." Through this series the Chronicle became the only newspaper in the state to examine EPIC in depth and attempt to deal with it as a campaign issue. Unlike many others, Professor Kreps analyzed Sinclair's economic strategy and the fundamental proposals of EPIC rather than his personality or past indiscretions. He maintained that Sinclair had miscalculated the situation in California, and pointed out that California did not have the idle land nor abandoned factories necessary to support EPIC proposals. Kreps also predicted the cost of EPIC, without existing state revenues which would be eliminated through Sinclair's tax plan, would bankrupt California by increasing the state's deficit from $\$ 130,000,000$ to $\$ 800,000,000$. Moreover Kreps pointed out that many of Sinclair's proposals had previously been tried in Russia but failed. The Chronicle further criticized EPIC through headlines to Kreps articles which declared: "Every Person is Coming", "Every Person is Concerned", "Everyone Pinched in California", "End California in 
Poverty", and "Exit Protection in California."141

In addition to the Republican Party and special interest groups in California, the state newspapers criticized the: Democratic Party platform, which somewhat modified Sinclair's EPIC proposals. The newspapers viewed the campaign issue as being Sinclair's principles versus the compromises he sanctioned. The Los Angeles Times made a major political issue out of Sinclair's modification of EPIC. For example, in the October 1 edition of the Times, Dr.. G.A. Briegleb, pastor of St. Paul's Presbyterian Church of Los Angeles, declared that no one could respect a man who had compromised as many of his promises as had Sinclair. When asked if he thought Jesus would support Sinclair, Briegleb replied that Jesus would not support any man who sacrificed his principles and promises for the sake of obtaining public office. ${ }^{142}$

Split in the Democratic Party

The nomination of Sinclair caused unrest and dissent within the Democratic Party. While this split in party allegiance is discussed more fully in Chapter IV, it is noteworthy because party discord was instrumental in Sinclair's defeat. Governor Merriam appealed to discontented Democrats declaring that "the defeat of Sinclair in California would not be regarded as the defeat of Roosevelt's administration. Party lines, Merriam asserted, had given way in a fight to preserve American principles, stating:

Progressives and conservatives, Democrats and

${ }^{141}$ San Francisco Chronicle, October 16, 1934, p. 6; San Francisco Chronicle, October 20, p. 10.

${ }^{142}$ Los Angeles Times, October 1, 1934, p. 1. 
Republicans, whatever their differences may be, stand on common ground when facing attacks on fundamental principles of American life and it happens that, in this crisis, I am fortunate as to be the representative of all who are resisting this attack. ...the socialist candidate on the Democratic ticket is not and never was a Democrat. He stands on a plan of his own, not on the Democratic platform. To use the graphic phrase of the steadfast life long Democrat, John J. Barrett, they are just 'taking the donkey for a ride. 143

In the final days of the campaign Merriam reaffirmed his national Democratic Party support first in a speech on October 19 which pledged his cooperation with the National Administration, and then on October 26 when he publicly praised Roosevelt on the Administration's attitude toward California relief.

$\underline{\text { Tom Mooney Case }}$

One of the major issues used against Sinclair in the final days of the campaign was the Tom Mooney case. Tom Mooney had been sentenced to death for his role in the Preparedness Day Bombing of 1916; as a result of the trial many controversial issues surfaced between labor and conservatives. Although his death sentence had been changed to life imprisonment, Mooney had never been pardoned. Sinclair declared his first act in office would be to free Tom Mooney. ${ }^{144}$

While no mention of Mooney was made in the Democratic Party's platform, through the campaign Sinclair continously associated his name with Mooney's cause. Throughout the campaign Sinclair corresponded with

143

3 Chico Record, October 18, 1934, p. 3.

${ }^{144}$ Sinclair, I, Governor of California, p. 50. 
the Sacramento Bee on the merits of the Mooney case. Sinclair stated his conviction that Mooney had been framed by the use of perjured testimony. 145

Sinclair's stand on the Mooney case weakened his support from 1abor forces. His association with the case hurt him in three ways: (1) it further identified him with radical movements, "Bohshevik agitators and anarchists"; (2) it weakened the support of labor organizations; and (3) it alienated the middle class.

\section{Literary Digest Po11}

The last blow to Sinclair's candidacy fell on November 3, three days before the election, when the Literary Digest poll was released. It showed Sinclair as the choice of only twenty-eight percent of the electorate while Governor Merriam was favored by sixty-three percent of those polled.

The result of the poll was tabulated from ballots sent throughout California; "700,000 ballots were sent to Californians of every class, occupation, and geographical section," asking each person to indicate his or her choice for governor among five candidates. Of the ballots cast, the Republicans led with 90,060; the Democrats were second with 36,857; the Progressive-Commonwealth parties received 16,890; the Communist Party got 584; and the Socialist Party had only 142 votes. All told only 144,533 ballots were cast. ${ }^{146}$

145 Sacramento Bee, September 25, 1934, p. 3.

146 "Merriam Tops Sinclair in Final Poll Report," Literary Digest, November 3, 1934, p. 5. 
Merriam received the majority of ballots cast in all but two communities, Fresno and Sacramento. Neither Sinclair or Haight obtained a majority in any of the counties. Merriam's strongest support was reported to be in Riverside, where eighty-three percent of the ballots were cast for him. Sinclair, according to the poll, was strongest in San Pedro, with forty-one percent of the vote. Haight's support centered in Fresno, where he received thirty-nine percent of the ballots. The state's two largest cities, Los Angeles and San Francisco, gave their support to Merriam. In San Francisco Merriam received sixty-four percent of the ballots; Sinclair twenty-seven percent; and Haight nine percent. Los Angeles, with one-fourth of the state's population, gave Merriam sixty percent of the vote; Sinclair twenty-eight percent; and Haight eleven percent. ${ }^{147}$ (For more complete statistical data refer to Appendix A.)

While the Literary Digest poll proved to be extremely inaccurate, it helped to defeat Sinclair. Sinclair later said that the poll "did us irreparable harm. It encouraged our enemies... it shifted the betting odds... many people were waiting to know which bandwagon to climb onto-and now they know." 148

\section{Vote Fraud}

In a final attempt to weaken Sinclair's strength among the poor and unemployed, the Republican opposition apparently tampered with voter registration procedures in an attempt to undercut Sinclair's support. On

$$
\begin{aligned}
& { }^{147} \text { Ibid., p. } 5 . \\
& { }^{148} \text { Sinclair, I, Governor of California, p. } 175 .
\end{aligned}
$$


October 16, a non-partisan group of voters, led by members of the Los Angeles County Republican Central Committee and Democratic Party leader Isadore Dockweiler, appeared before the Los Angeles County Board of Supervisors. They charged that there was a plot to allow 100,000 illegal votes to be cast in the November election. Upton Sinclair and his supporters were blamed for the fraud with the names.of the alleged illegal registrants being supplied by the Los Angeles Republican Assembly. Based upon a survey, the registrants had illegally registered giving false addresses and information. ${ }^{149}$. The majority of the illegal registrants came from the downtown working class district and in areas with high minority concentrations. ${ }^{150}$ California State Attorney General U.S. Webb declared each individual had to show cause why he should not be refused a ballot; placing the burden of proof upon the individual and not upon the law enforcement agencies. On October 18 Assistant Attorney General Howie filed an injunction against 24,136 accused fraudulent registrants in Los Angeles, while the Grand Jury began its investigation. ${ }^{151}$

Sinclair charged that the plot had been conceived by Albert Parker of the United for California League and a group of wealthy Republican supporters. As a result of the opposition's attempt to disenfranchise so many voters, Sinclair predicted a civil war in California if the individuals in question were unable to vote. 152

\footnotetext{
149

Los Angeles Times, October 17, p. 1.

150 "The EPIC of Upton Sinclair," p. 495.

${ }^{151}$ Los Angeles Times, October 20, 1934, p. 1.

${ }^{152}$ San Francisco Chronicle, October 24, 1934, p. 9.
} 
The major newspapers inferred that the illegal registrants were transients who desired to vote for Sinclair. On October 23 the San Francisco Chronicle printed an article by Leslie H. Kraz, chairman of the law enforcement committee of the Democratic State Central Committee, which charged that the existence of a "conspiracy to disenfranchise and intimidate thousands of voters and that violence is inevitable." Yet when several Los Angeles residents, including Gurney E. Newlin, former president of the American Bar Association, applied to the State Supreme Court to bar the disqualification proceedings, the Chronicle claimed that Sinclair was attempting to stop the illegal registration probe. ${ }^{153}$

On October 31, the State Supreme Court issued a writ which ordered the proceedings to be discontinued and the Webb suit stopped. ${ }^{154}$ As a result of the court's decision the disenfranchised voters were allowed to cast their ballots on November 6. After the general election the State Supreme Court also ordered an investigation of the Republican charges against Sinclair.

$\underline{\text { Summary }}$

The tactics employed by Sinclair's opposition were successful, so much so, that by election day gamblers set the odds against Sinclair at five to one. ${ }^{155}$ Together the methods used to defeat Sinclair by the Republican Party and the state's special interest groups instilled a

${ }^{153}$ San Francisco Chronicle, October 21, 1934, p. 4; San Francisco Chronicle, October 23, 1934, p. 1 .

${ }^{154}$ San Francisco Chronicle, October 24, 1934, p. 9. 155 "No Contest," Time, November 5, 1934, p. 12. 
powerful fear of EPIC and Sinclair in the voters. Sinclair predicted the election outcome, when on November 3, over statewide radio hookup, Sinclair charged:

Your minds have been poisoned with a lie barrage... How long will it be before the people will make up their minds to have comfort and safety rather than want... It is your problem, not mine, and your suffering. If you want more of it, it's your God-given right to have it. 156

Sinclair, unlike his opponents, announced that if defeated he could return to his writings.

It was apparent that the Democratic drive was faltering. After the initial triumph in the primary and apparent convention harmony, the opposition's tactics weakened the Sinclair candidacy. With the press, business and industry, and religious organizations working against him, Sinclair found few areas of support.

${ }^{156}$ Sinclair, The Lie Factory Starts, p. 124. 
CHAPTER IV

POLITICAL REACTIONS AND ATTITUDES

Utopian images aroused by Sinclair frightened both the left and right wing parties. Socialist Howard Zimm viewed EPIC as a solution to the depression, one "which extended the boundaries of political and economic imagination beyond those of the New Dealers--sometimes to the left, sometimes to the right." The Los Angeles Times described the Merriam-Sinclair contest in this way:

(The) contest is not a fight between men, it is a vital struggle between constructive and destructive forces... Sinclair is a visionary, a consorter with radicals, a theorist... .No Democrat by the wildest stretch of the imagination... Sinclair is a political opportunist, whose sole chance of political success lies in his ability to fool a majority of the electorate.

Sinclair's EPIC movement was characterized as "Socialistic", "Collectivistic", and "Bolshevistic" by opponents within the Democratic and Republican parties. ${ }^{157}$

Party regulars asserted that the traditional American system was threatened by "Socialism working through old party lines." Political analysts warned of impending splits in both parties. According to the

157 B.K. Johnpo11, Pacifist's Progress: Norman Thomas and the Decline of American Socialism (Chicago: Quadrangle, 1970), p. 134; Los Angeles Times, September 29, 1934, p. 4; John R. Owens, Edmund Costantine, and Louis Weschur, California Politics and Parties (London: Macmillan, 1970), p. 39. 
San Jose News, it was the "duty of good, sane sensible Republicans and Democrats alike to select the candidate who will poll the largest vote possible in order to defeat Sinclair..." While Merriam was regarded by many as the "tool of the privately owned public utility corporations," Sinclair was branded as a visionary whose schemes would bring "utter confusion, economically, politically and financially." Socialists and Communists also criticized Sinclair as a "Social Fascist", "renegade", and "visionary" who proposed a quasi-Socialist program with a "quack remedy." Socialist Party leaders were outraged by campaign charges that Socialists were allied with the Republican and Democrats in an effort to defeat Sinclair. ${ }^{158}$

To those more tolerant of Sinclair, EPIC and its supporters were characterized not as radicals, but reformers who "did not seek to transform the system, only to make it more humane... Their committment to reform was greater, their intolerance for injustice far less." To others EPIC represented an "amorphous mixture of libertarianism, rationalism and humanism." Republican Senator George Norris wrote, "Such men as Upton Sinclair are anșwering the cry for progress." 159

\section{REACTION OF STATE DEMOCRATIC LEADERS}

Although the nomination of Sinclair on the Democratic ticket was

\section{8}

Sacramento Bee, August 29, 1934, p. 22; San Jose News, July 7 , 1934, p. 1; "Merriam Tops Sinclair in Final Poll Report," p. 5.

159

Sinclair, I, Candidate for Governor: And How I Got

Licked, p. 155; AI Richmond, Along View from the Left:

Memoirs of an American Revolutionary (New York: Thomas

Crowe11, 1972), p. 68; Sinclair; I, Governor of California, p. 1 . 
anticipated, the degree of his success in the primary and his party's nomination surprised many old line Democrats. The first reaction of the state party leaders was silence.. Senator McAdoo and George Cree1, McAdoo's candidate in the primary election, refused to make a statement on the outcome of the primary or on their plans. They stated only that they would wait until after the state convention on. September 20 in Sacramento to decide a position. Justus Warde11, a candidate in the primary election, at first refused to congratulate Sinclair. Then on September 1, Warde11 announced that he would support the candidacy of Governor Merriam. On September 19, Creel announced that he felt the platform adopted would be acceptable to all Democrats. As a result Sinclair predicted that the convention would bring "harmony and reconciliation between the Bourbons and the EPIC forces." 160

Prior to the convention many conciliation meetings were held in an attempt to unite the various Democratic factions. Sinclair first visited Senator McAdoo and his law partner, Colone1 Neblett, and then George Creel. Sinclair was accompanied at these discussions by Culbert 01son, EPIC candidate for the State Senate from Los Angeles County, Richard Otto, Sinclair's campaign manager, Sheridan Downey, EPIC candidate for lieutenant governor, and John Beardsley and John Packard, both Sinclair's advisors and lawyers. Of the two state party leaders, only Creel publicly advocated party unity; in fact, Creel eventually wrote the planks dealing with labor affairs in the platform. In exchange for the Creel

${ }^{160}$ San Francisco Chronicle, September 10, 1934, p. 3; Los Angeles Times, September 20, 1934,..Pt. I, pp. 1-2. 
faction's support, Sinclair agreed to sever relations with Justus Warde11. 161

The Democratic State Central Committee Convention was convened on September 20 in the Assembly Chambers of the State legislature in Sacramento. Unlike previous conventions the galleries were filled with boisterous crowds, the majority of which were Sinclair supporters led by a cheer leader. One group of EPIC supporters attempted to remind the delegates of their commitments with a large banner hung from the balcony that read:

$$
\begin{aligned}
& \text { EPIC--NO COMPROMISE } \\
& 469,000 \text { voters }
\end{aligned}
$$

The Sinclair forces controlled the convention, their power second only to the political strength of Senator McAdoo and George Creel. ${ }^{162}$

As Sinclair had hoped, the convention was harmonious, with the feeling of part unity being prevalent. The convention concluded on a high note, with Senator McAdoo endorsing Sinclair. Then too, Forrest Downey, Milton K. Young, Z.T. Malaby and William McNichols, four of the minor candidates in the Democratic primary, endorsed Sinclair. ${ }^{163}$ Sinclair left the convention confident that he had received the support of McAdoo, Creel and Maurice Harrison, chairman of the State Central Committee. Also predictions by Isadore Dockweiler, a prominent Democratic Party leader, that many Democrats would desert the party if Sinclair was the

${ }^{161}$ Sinclair, I, Candidate for Governor: And How I got Licked, p. 102 .

${ }^{162}$ Los Angeles Times, September 21, 1934, Pt. I, p. 1; Sacramento Bee, September 20, 1934, p. 5.

163 New York Times, August 30, 1934, p. 1. 
nominee, were dispelled.

In an attempt to unite party factions the convention drafted a platform meant to appeal to the majority of Democrats. ${ }^{164}$ The platform committee, with EPIC supporters in the majority, consisted of Sinclair, Downey, Olson, Otto, Judge Francis Carr, F.J. Hennessy and Colone1 W.H. Neblett. The committee modified Sinclair's original plan: communal farms, the old age pension, and the proposal to repeal sales tax, were among the items eliminated. As previously agreed with Creel, specific details were altered but the platform incorporated the basic EPIC principles in its major planks. ${ }^{165}$ Creel then publicly supported EPIC with an annoumcement that "instead of being a Sinclair platform, our State platform is one upon which any Democrat can stand:"166 The Democrats "pledged themselves to protect. the purity and sacredness of the American home, to protect ownership of property and property rights that were not in conflict with the general welfare," while also committing "themselves to a policy of putting the unemployed at productive labor, enabling them to produce what they themselves are to consume."167

Tranquility was shattered on the last day of the convention when Culbert 01son was elected state chairman of the Democratic Party over Colonel William Neblett. Bitter at the outcome Neblett denounced

${ }^{164}$ The Democratic Party's platform was a combination of EPIC and a revised New Dea1.

165 Sacramento. Bee, September 20, 1934, p. 1 .

166"Industrial Truce to Face as Election Nears," Literary Digest, October 13, 1934, p. 3 .

${ }^{167}$ EPIC News, September 24, 1934, p. 8. 
Sinclair as a Communist, and joined the Merriam forces. ${ }^{168}$ He also denounced the Democratic platform as having "slid right back into the mire of communism." Neblett asserted that Sinclair's Democratic nomination only "concealed the communistic wolf in the dried skin of the Democratic donkey." 169 This important party leader's denunciation began a long list of Sinclair desertions.

Other Democratic defections of party regulars quickly followed. Hamilton Cotton, Creel's campaign manager and head of the Works Progress Administration in Los Angeles, stated that Sinclair had been nominated by "200,000 to 300,000 malcontents," and called the Democratic platform a "revised edition of Grimm's Fairy Tales." He later announced the formation of the American Democracy of California, an organization which supported Merriam. The Wardell forces organized their own group called the Loyal Democrats of California which gave its support to Merriam. Matt Sullivan, former Chief Justice of the State Supreme Court, organized the Democrats for Governor Merriam Campaign Committee, a group which maintained that Sinclair would "Russianize California and inflict on our people the curse of Communism." Maurice Harrison also announced that he could not support the Sinclair candidacy. 170

Despite attempts to unite factions, party leaders continued to desert Sinclair for Merriam or Haight. Even the support of the McAdoo and Creel factions were questionable. By the first. of October, McAdoo

${ }^{168}$ New York Times, October 30,1934, p. 1.

${ }^{169}$ Los Angeles Times, October 13, 1934, Pt. II, p. 5.

170 Sinclair, I, Candidate for Governor: And How I got Licked, p. 146. 
had left California for the East by way of Mexico City. In Mexico City Thomas M. Starke, McAdoo's advisor, stated to the press that Sinclair did not stand a chance of becoming governor of California. Starke estimated that Sinclair would lose the race by at least 200,000 votes. When McAdoo arrived in Washington, D.C., he stated that he too was uncertain of a Democratic victory in California, reaffirming Starke's earlier comments. On November 5, the day before the election, McAdoo urged the election of Democratic Congressmen but made no reference to the Sinclair candidacy. ${ }^{171}$

George Creel also left California for the East to obtain financial support for his literary endeavors. He announced from Washington, D.C., that Sinclair could win if he ran on the convention platform claiming that, "at the convention we threw out almost everyone of his planks." On October 23, Creel suggested. to newsmen that he might not support Sinclair. By October 27 Creel's position was made clear in a public letter to Sinclair, dated October 18, in which he stated Sinclair had violated a pledge to abandon his platform of "Immediate EPIC" in favor of a compromise plan. The major point in dispute was the book Immediate EPIC, which, Creel asserted, ignored the compromises of the convention and pushed for his original EPIC plan. Creel therefore announced he would vote for Merriam, even though "Merriam stands for everything I have fought against for thirty years." 172

Creel's position was reinforced in the feature article of the

${ }^{171}$ San Francisco Chronicle, October 5, 1934, p. 1; Los Angeles Times, November 4, 1934, p. 1.

${ }^{172}$ New York Times, October 6, 1934, p. 6; New York Times, October 27,1934, p. 1 . 
October 27 edition of the Saturday Evening Post, entitled "Utopia Unlimited." In this article Creel denounced EPIC, claiming that the plan was economically unfeasible. Creel again accused Sinclair of espousing a platform other than the one adopted at the Democratic state convention in September. ${ }^{173}$

On October 31 Isadore Dockweìler, an influencial Democratic leader, former Democratic national committeeman, and supporter of the Wardell primary forces, reaffirmed his support for Merriam. He denounced Sinclair as a Socialist with communist sympathies, who was attempting to use the Democratic Party to establish "a socialistic state in California." 174

By election day, Sinclair did not have the support of the state Democratic leaders. While McAdoo remained non-commital, his associates, including Neblett, Harrison, Cotton, and Creel, deserted the Sinclair cause. As the leading California Democrat, McAdoo recognized the political need to remain silent on Sinclair's candidacy.

REACTION OF COUNTY AND LOCAL DEMOCRATIC LEADERS

While most state Democratic leaders remained non-commital on Sinclair's candidacy until the September 20 convention, repudiation of Sinclair by local leaders commenced immediately following the primary elections. John B. Elliott, vice-chairman of the Democratic state organization, announced his support of Raymond Haight on August 30 . On

${ }^{173}$ George Cree1, "Utopia Unlimited," Saturday Evening Post, October 27, 1934, p. 5.

${ }^{174}$ Los Angeles Times, October 30,1934, p. 1. 
September I, Matt I. Sullivan, a progressive Democrat, announced his support of Governor Merriam, and on September 2 John L. Flynn, former Collector of Revenue, David F. Supple, a member of the Democratic state committee, and Henry E. Monroe, president of the Democratic Club of San Francisco, announced their denunciation of the Sinclair candidacy. Also Avery C. Moore resigned from the Democratic State Central Committee rather than back Sinclair. 175

Major J. Ed Hughes, member of the Democratic State Central Committee for thirty-eight years, announced his support of Haight. He declaxed that the election of Merriam, "a reactionary of the worst type," would be a disaster; the election of Sinclair, "a red radical," would be a calamity. 176 Peter P. Myhand of Merced, a member of the California State Board of Agriculture, and Judge Henry C. Gesford of Napa County, a member of the Democratic Party for fifty-seven years, also announced their support for Haight.

Denunciation of the Sinclair candidacy continued from such Democratic leaders as James Donovan, former attorney general of Montana, and a Los Angeles lawyer, Thomas $0^{\prime N}$ Neil, president of the California Vegetable Union, and William Jennings Bryan, Jr., a Los Angeles Democrat. Bxyan, who organized the League of Loyal Democrats, ran unsuccessfully against Sheridan Downey in the primary race for lieutenant governor, summarized party concerns, declaring that Sinclair was a "Socialist interloper" who offered "not a single new or progressive idea and whose

\section{${ }^{175}$ Los Angeles Times, September 5, 1934, p. 1. ${ }^{176}$ Fresno Bee, September 5, 1934, p. 3.}


EPIC program is but a rehashing of the declaration of principles of the Anarchist-Communist Party." 177

J. Pendleton Wi1son, prominent member of the San Francisco Democratic Club, Edward H. Heller, San Francisco broker and important leader in the Creel campaign, Colonel.W. Scott Smith, president of the San Mateo County Democratic Club, Nathan Newby, Los Angeles attorney, and Eleanor Banning MacFarland, a member of one of California's oldest families, were among many. other local Democratic leaders who found that they could not support Sinclair. Seth Millington of Northern California, former commander of the state American Legion, Joseph P. Tumulty, secretary to President Woodrow Wilson, called upon Democrats to defeat Sinclair.

Zach Lamar Cobb, Los Angeles attorney and active Democrat, challenged any Democrat leader in the state to debate the Sinclair candidacy with him. He would debate the issue with anyone who believed that the election of Upton Sinclair as governor of California would not ruin more industries and businesses than Sinclair proposed to create and would not put more people out of work than he proposed to employ. Cobb insisted that any Democratic leader who might accept the challenge had to show proof of party membership for a reasonable period of time. ${ }^{178}$

Many of these local Democratic leaders headed anti-Sinclair organizations during the campaign. The Democrat-Merriam for Governor Campaign Committee, American Democracy of Ca1ifornia, United for California

\footnotetext{
${ }^{177}$ Los Angeles Times, September 21, 1934, Pt. I, p. 4. ${ }^{178}$ Los Angeles Times, October. 4, 1934, Pt. II, p. 3.
} 
League, Democrats United Against Sinclair, California League Against Sinclairism; and the Veteran's Non-Partisan League were but a few of these organizations. J. Pendleton Wilson, Matt I. Sullivan, Leonard Worthington, and James Miller were active executives of the DemocratMerriam for Governor Campaign Committee; the American Democracy of California could list such supporters as H.H. Cotton, James L. Beebe, chairman of the Southern California forces of Creel for governor, Mrs. Eleanor Banning MacFarland, W.H. Anderson, Mrs. Harold B. Wrenn, and Ralph Ryan.

The Democratic Confederation of California also endorsed Governor Merriam because Sinclair had been a Democrat for only thirteen months and had opposed the election of Roosevelt in 1932 and other Democratic candidates. The confederation also declared that the "political fortunes of Sinclair depended upon the backroom compromises with Senator William Gibbs McAdoo, George Creel, and Maurice Harrison and other patronage dispensers. 179

Members of county Democratic committees also left Sinclair in increasing numbers as the campaign entered its final days. Most county committees faced partial, if not complete, desertions by party members in favor of Merriam or Haight. Out of some fifty-seven Democratic County Central Committees, Sinclair had the allegiance of only twelve, with an overwhelming majority of county committees in Northern California aligned against him. 180

${ }^{179}$ San Francisco Chronicle, September 16, 1934, p. 9. ${ }^{180}$ Los Angeles Times, October 27, 1934, p. 6. 
Desertions increased with the publication of an interview given by Sinclair to: Jay G. Hayden of the Detroit News. Hayden had asked Sinclair what the difference was, in his view, in the Socialist and Democratic tickets. Sinclair replied:

I found that I was not getting anywhere as a Socialist and so I decided to try to make progress with one of the two old parties...I haven't changed my ideas, I have merely changed my techniques.

Sinclair's response reaffirmed Democratic Party regulars' fear that the issue of the campaign was not Republican versus Democrat, but "Americanism vs, radicalism." 181

REACTION OF THE NATIONAL DEMOCRATIC LEADERS

During the primary campaign in California, James A. Farley, chairman of the Democratic National Committee, had given official party support to the candidacy of George Creel. The victory of Sinclair in the primary campaign had thus placed the Roosevelt Administration in a difficult position. The administration was forced to acknowledge Sinclair's candidacy since he was selected by a majority of the Democrats of the state to represent them in the general election. In the interest of party unity, Farley gave, reluctantly, the national party and the administration's approval to Sinclair. However the usual congratulatory telegram from the National Democratic Committee was not sent to Sinclair, an action which possibly indicated the administration's lack of full support.

${ }^{181}$ Los Angeles Times, October 7, 1934, p. 3; Jon A. Yoder, Upton Sinclair (New York: Fredrick Ungar Publishing Co., 1975), 
Immediately following Sinclair's primary victory, Sinclair announced that he would request an interview with President Roosevelt and national party leaders in. Washington, D.C. James A. Farley declared that the party organization should do everything possible to aid Sinclair since he was the official nominee of the Democratic Party. He told reporters, "The party has never failed to support its nominees." J.F.T. O'Connor, Comptroller of the Currency and close political ally of Senator McAdoo, thought that support should be delayed until."more was known about Sinclair's specific intentions."182 President Roosevelt authorized, however, an interview with Sinclair on the condition that the EPIC campaign would not be discussed during the interview. Sinclair accepted the President's terms and left by train for Washington on September 2 .

The President's meeting with Sinclair created a complex dilemma for Roosevelt, which forced him to remain politically neutral. If Roosevelt endorsed Sinclair, conservative Democratic leaders such as John W. Davis, Albert Ritchie, and Newton D. Baker would be alienated from the administration at a time when the New Deal was seeking their support. If he repudiated Sinclair, Roosevelt would have weakened his strength among many liberal Democrats who had supported him in 1932. ${ }^{183}$ Then too, because of accusations by the American Liberty League that Roosevelt's

${ }^{182}$ Charles E. Larson, "EPIC Campaign of 1934," Pacific Historical Review, XXVII (May, 1958), 139-40.

${ }^{183}$ Donald Singer, "Upton Sinclair and the California Gubernatorial Campaign of 1934," Southern California Quarterly, LVI (Winter, 1974), 387. 
administration was moving to the left, an endorsement of Sinclair would have confirmed their charges. Members within the Roosevelt administration maintained that official recognition of Sinclair would force conservative Southern Democrats from the party, weakening Roosevelt's re-election chances in 1936. Also. Roosevelt and his advisors did not want either to alienate the Democratic Party leaders in California nor to be associated with a "1oser."184

On September 4 Sinclair met with the President at Hyde Park, New York, to seek his endorsement. Sinclair intended to obtain approval from Roosevelt, if he won the election, to use federal funds in support of the EPIC plan. Through federal relief funds sinclair stated he could buy the means of production rather than give it in direct relief. Aware of Roosevelt's refusal to discuss politics, Sinclair was encouraged to learn that the President had read I, Governor of California and How I Ended Poverty, and was familiar with the EPIC plan. 185

The two men talked for two hours, forty-five minutes beyond Sinclair's allotted time. After the interview, both Sinclair and Roosevelt left with some misunderstandings about what was said and agreed to in the discussions. According to Sinclair, after having elaborated on the details of EPIC, Roosevelt stated that "I am coming out in favor of production for use... It will be somewhere about the 25 th of October," to which Sinclair replied, "If you do that, Mr. President, it will elect

${ }^{184}$ Richard Antognin, "The Role of A.P. Giannini in the 1934 California Gubernatorial Election," Southern California Quarterly, LVII (Spring, 1975), 78.

${ }^{185}$ Sinclaix, I, Candidate for Governor: And How I got Licked, p. 76. 
me."186 Sinclair left the discussions secure that presidential support would be forthcoming. Whether or not Roosevelt misled Sinclair is not known, but the endorsement was never received.

Following the meeting Marvin McIntyre of the White. House secretarial staff stated to reporters that Roosevelt had a non-political discussion with Sinclair and that he could not endorse Sinclair because "he does not interfere in local elections." ${ }^{187}$ Roosevelt's attitude toward the Sinclair candidacy was summed up in a letter to Senator Key Pittman of Nevada:

In regard to the gentleman from California, I suppose that if matters come to a head and he takes my name in vain, the only possible answer is the one we have used before-- 'The President' has taken no part in regard to any matter of policy, party or candidate in any state election; he is taking no part, and will. take no part. 188

The promises of Roosevelt, supposedly received by Sinclair, later caused him a great deal of trouble in the campaign in California. Sinclair's credibility was weakened without a Presidential endorsement of EPIC.

Off the record Roosevelt told J.F.T O'Connor, the Comptroller of the Treasury and a veteran California politican, that Sinclair made a "favorable impression" at their September meeting. To the President, EPIC represented the impulse to experiment which he considered the essence of America. Roosevelt agreed Sinclair was a "crank," but "cranks

186

Ibid., p. 77.

${ }^{187}$ Larsen, "EPIC Campaign of 1934," p. 140.

${ }^{188}$ Elliott Rooseve1t, ed., F.D.R.: His Personal Letters

(New York: Due11, Sloan and Pearce, 1950), p. 426. 
had contributed a good deal to social progress." 189 Roosevelt went on to state:

The beauty of our State and Federal system is that the people can experiment. If it has fatal consequences in one place, it has little effect upon the rest of the country. If a new, apparently fanatical, program works we11, it will be copied. If it doesn't, you won't hear of it again.190

The President, however, stated to the press that EPIC as a statewide program was "impossible."191

After meeting with President Roosevelt, Sinclair met with other Democratic leaders in Washington. Discussions were held with James A. Farely, chairman of the Democratic National Party; Jacob Baker, chairman of Surplus Relief Corporation; John Fahey, chairman of the Home Owner's Loan Corporation; William H. Myers, governor of the Farm Credit Administration; J.J. Thomas, governor of the Rederal Reserve Board; Harold L. Ickes, Secretary of the Interior; Jesse H. Jones of the Reconstruction Finance Corporation; Secretary of the Treasury Henry Morgenthau; and Harry Hopkins, director of the Federal Emergency Relief Administration. Of these national leaders only Hopkins openly supported the Sinclair candidacy. Hopkins publicly declared "...I'm for him (Sinclair). He's

${ }^{189}$ Schlesinger, Politics of Upheavel: The Age of Rooseve1t, p. 117.

${ }^{190}$ Francis Perkins, Roosevelt I Knew (New York: Viking Press, 1946), p. 124.

${ }^{191}$ Schlesinger, Politics of Upheavel: The Age of Rooseve1t, p. 117. 
on our side. A Socialist? of course not. He's a Democrat. A good Democrat." 192

Sinclair's candidacy was weakened, however, when Hopkins informed the Washington press corp that if Sinclair were elected governor, there would be an influx of unemployed moving to California. Sinclair, said he had asked Hopkins if the Federal Emergency Relief Administration would temporarily help these individuals until they could be absorbed into the EPIC program. Sinclair further antagonized the California establishment and national administration by stating that he expected EPIC would drive many capitalists from California. ${ }^{193}$

Raymond Moley, a Roosevelt brain truster, publicly denounced EPIC in an October editorial in the magazine Today. He criticized the EPIC plan as a "back to nature" movement which ignored modern economic realities. Moley further expressed his views, stating:

I do not believe that Upton Sinclair's plan to end poverty will end poverty. I do not believe it sound and progressive economics. I do not believe it to be consistent with the essential policies of the New Deal. And I do not believe it is intellectually honest to say that it must be tried before it can be condemned.

To want to see a. scrambled hodge-podge of proposals, some sound and some absurd, tried out under the leadership of a man with no experience in practical administration is to confess the failure of whatever has been done in centuries of slow development of political institutions in the United States and abroad.

Moley's views were regarded by many as representing New Deal philosophy.

192 Larsen, "EPIC Campaign of 1934," p. 142.

${ }^{193}$ San Francisco Chronicle, September 6, 1934, p. 4. 
Many referred to Moley as "the official spokesman for the New Deal." Moley's sentiments were reinforced on October 26 when the President informed reporters that, "I cannot take part in any state campaign."194

In their attempt to align themselves with the resurgent national administration, EPIC forces made a serious mistake. The Democratic Speakers Bureau announced that Sinclair would receive the endorsement of Harold Ickes, Harry Hopkins, Senator George Norris of Nebraska, Governor 01sen of Minnesota, and Senator William McAdoo. ${ }^{195}$ Forced by the EPIC announcement to declare their positions, Hopkins announced he would take no part in Sinclair's campaign. Secretary Ickes and Senator Norris both stated they would not appear or speak for EPIC or Sinclair. The renunciation of these national leaders reinforced the charge that the New Deal did not support the Sinclair candidacy and wished to disassociate itself from the California campaign. 196

That October the Roosevelt administration further alienated EPIC supporters. When Culbert 01son, chairman of the California Democratic Central Committee and EPIC follower, requested an appointment for an interview with the President he was refused.

On October 21 Chauncey Tramutolo, a candidate for United States Representative from the Fourth District, stated that he would rather be defeated than go to Congress with the EPIC label attached to him. He declared that he did not consider Sinclair a Democrat and according to reliable information, the Roosevelt administration held the same opinion.

\footnotetext{
${ }^{194}$ Los Angeles Times, October 5, 1934, Pt. II, p. 4. ${ }^{195}$ EPIC News, October 8, 1934, p. 7. ${ }^{196}$ San Francisco Chronicle, October 19, 1934, p. 1.
} 
On October 30 Farley sent a telegram to Tramutolo wishing him success in his campaign. Sinclair never received such a telegram. ${ }^{197}$

Then, on October 27, Jim Farley found himself in an embarrassing position. A letter sent by Farley's office had been received by prominent California Democrats recommending the election of Sinclair for governor. Apparent1y the letter was written by Farley to Eugene Troskey, president of the Associated Clubs of Whittier. The letter bore Farley's famous green ink signature. Farley declared he had no knowledge of the letter of endorsement. Emil Hurja, secretary of the Democratic National Committee, told the press that the distribution of the letter was the result of an undetected clerical error. It was reported that President Roosevelt himself reprimanded Farley for his carelessness in the matter. 198

In the final days before the election, Sinclair's campaign was further weakened by the rumor that he was about to withdraw from the race in favor of Haight. In an attempt to dispel the rumors, Sinclair stated that he would fight to the finish and never withdraw. ${ }^{199}$ The Roosevelt administration, which believed that Sinclair would bring the entire Democratic Party to defeat, attempted to persuade Sinclair to reconsider and withdraw. Sinclair's withdrawal was not forthcoming, so the national administration developed a plan to eliminate Sinclair from the race. The key individuals charged with the execution of this administration plan

${ }^{197}$ San Francisco Chronicle, October 31, 1934, p. 1. 198 "Politics," Newswèk, November 3, 1934, p. 139.

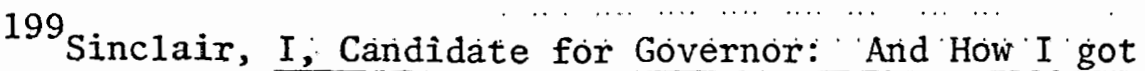
Licked, p. 186. 
included A.P. Giannini, president of the Bank of America and a prominent Roosevelt supporter; J.F.T. O'Connor, a former member of the California law firm of McAdoo, Neblett and $0^{\prime}$ Connor and Comptroller of the Currency; and Raymond Haight, candidate for the governorship of California on the Progressive ticket. Administration officials McIntyre, Farley, and Morganthau met and decided to send $0^{\prime}$ Connor to Los Angeles to persuade Sinclair to withdraw from the race. 200

Four reasons were given as to why Sinclair's withdrawal would benefit the New Deal administration. First, the withdrawal of Sinclair would assure Democratic Congressmen of election. Second, Sinclair's withdrawal would "eliminate bitterness and ill will that would follow Sinclair's defeat among his supporters!' who would blame the administration for not taking a more active part. Then, Sinclair's absence would recall from the Republican ranks "thousands of independents and Democrats who have expressed themselves for Merriam." Finally, if Haight was elected, President Roosevelt would be assured the electoral vote of California in 1936. 201

O'Connor did meet with Sinclair on October 30 and the newspapers inferred that he had asked for Sinclair's withdrawal. However, O'Connor denied the report. As a result Sinclair's candidacy entered the election month of November without the support of the local Democratic leaders, the state party leaders, or the endorsement of Franklin Roosevelt.

200 San Francisco Chronicle, October $28 ; 1934$, p. 1. ${ }^{201}$ Russe11 M. Posner, "A.P. Giannini and the 1934 Campaign in California," Southern California Quarterly, LVI (Winter, 1974), 196. 


\section{REACTION OF THE REPUBLICAN PARTY LEADERS}

The Republican Party leadership reacted to the candidacy of Sinclair in two ways. Until the August 28 primary, the Republicans were indifferent to Sinclair and his EPIC program, viewing him as an improbable November contender for the gubernatorial race. Second, noting Sinclair's margin of victory, the Republican Party feared a possible Democratic victory in the general election. The Republicans viewed Sinclair as a threat to the state and to the party's control of state government. While they despised Sinclair's program and his Socialist past, they were frightened of his potential vote appeal and realized that a tough campaign would be needed to defeat Sinclair. Yet, of all the possible Democratic candidates for the Republicans to oppose, Sinclair was seen by the Republican leadership as the most vulnerable candidate because of his controversial background and writings.

The Republican leadership feared the candidacy of Sinclair, seeing EPIC as a threat to business, property, government, and the state. Major business interests in the state were aligned behind the Republican Party. Ardent Republican Party supporters against Sinclair included state and local Chamber of Commerce groups, the Association of Farmers of California, citrus growers, oil barons, the Newspaper Publishers Association, California service clubs, university faculties, school boards, the Federation of Women's Clubs, and parent teacher organizations. 202

Governor Merriam stated that the nomination of Sinclair had made

${ }^{202}$ Richmond, Along View from the Left: Memoirs of an American Revolutionary, p. 11 . 
the issue of the campaign one of Americanism or Socialism. Earl Warren, future governor of California, then state Republican chairman, declared that the issue was one against radicalism and socialism: Republicans called EPIC proposals "flimsy and unreal...utterly misguided...completely impossible of realization...dangerously unsafe and destructive.". Sinclair's program, asserted Merriam, "contemplates superstructure of taxation upon a people already hard pressed by an endless chain of local, state and federal taxes." Sinclair, he added, has made promises which he "cannot carry out if elected." 203

The Republican platform adopted at the September 20 convention in Sacramento, stated that all forces in California must join together to insure the defeat of Sinclair. "We urge an active and aggressive campaign of Americanism and liberalism against radicalism and the threat of Communistic adventure in California..." Ex-governor Friend Richardson addressed the convention and said, "What...are you afraid of? He's (Sinclair) not a Democrat. He's a Socialist." The Republican platform further praised the incumbent administration and denounced the EPIC proposals. $^{204}$

Due to Sinclair's potential threat to the Republican Party, Merriam called the legislature into special session on September 13 for the stated purpose of decreasing the then increasing debt load of the state. However Merriam's primary goal was to force the passage of

\footnotetext{
203 "Industrial Truce to Face as Election Nears," p. 3. ${ }^{204}$ Los Angeles Times, September 21, 1934, p. 2; Sacramento Bee, September 21,1934, p. 5.
} 
measures dealing with old age pensions, assistance for unemployed, and relief for certain classes of debtors. Nicknamed the "legislative session of a thousand blunders," it did draft a $\$ 24,000,000$ bond issue for unemployment relief to go before the voters on the November ballot. 205 The measures followed recommendations established by, the federal relief authorities. Merriam believed:

There can be no question of the fact that a very broad and far reaching program must be carried out by the State government of California looking not only to the care of the unemployed, the sick and disabled, and the aged, but also to the establishment of agencies concerned with the restoration of sound economic conditions throughout the State.

Greater social justice, guaranteed by statute and by state policy, must be our goal. 206

As a result of Merriam's maneuver, many of Sinclair's programs were neutralized by measures passed in this special session. The legislature accepted Merriam's program with only minor reservations. Merriam benefited in the campaign from this session for it helped perpetuate his self-made image as "the emblem of the American ideal of government."207

\section{SOCIALIST PARTY}

The Socialist Party in California denounced Sinclair as a "renegade" and warned the public to distrust him. Due to Sinclair's alignment with the Democratic Party, the State Executive Committee of the

\section{5}

Sacramento Bee, September 15, 1934, p. 1 .

${ }^{206} \mathrm{H}$. Brett Melendy and Benjamin Gilbert, The Governors of California from Peter H. Burnett to Edmund G. Brown (Georgetown, Ga.: Talesman Press, 1965), p. 384 .

${ }^{207}$ San Francisco Chronicle, September 2, 1934, p. 8. 
Socialist Party, on September 20, 1933, expelled Sinclair from the party at a Los Angeles convention as being "opportunistic" and "no 1onger proletarian." The Executive Committee further stated that it had "no faith in the possible accomplishments of one man, no matter how sincere that person may be." 208

The Socialist Party in California held a convention in September and issued their own program. Milen Dempster, the nominee for governor, repudiated Sinclair saying "Sinclair is no longer a socialist and we are not supporting him." Additionally he said EPIC was a quack remedy that was unable to cure the serious ills of capitalism. 209

Norman Thomas, leader of the American Socialist Party, was extremely critical of Sinclair's EPIC program, labelling it as a "tincan economy" that was "economically and politically absurd" and was "quite visionary." "The details of what he proposes to do will eventually overwhelm him." While EPIC was "socialist in inspiration", Sinclair had "promised the impossible." Therefore Thomas maintained that Sinclair's election would be "a tragedy to himself and the cause of radicalism." Unlike Sinclair, Thomas asserted that it was impossible to abolish poverty without defeating the entire capitalist system. Sinclair's candidacy, Thomas pointed out:

a disquieting tendency on the part of even our friends to talk left but to act right; to praise

${ }^{208}$ Singer, "Upton Sinclair and the California Gubernatorial Campaign of 1934," p. 388; Robert Orlway Foote, "The Radical vs. Conservative Issue on California," Literary Digest, September 8, 1934, p. 8; Los Angeles Times, September 22, 1933, Pt. II, p. 5 .

${ }^{209}$ San Francisco Chronicle, September 21, 1934, p. 6. 
Russia and be somewhat skeptical of socialism; as perhaps not radical enough, and then to rush off--as Upton Sinclair appears to be doing, to try to capture a Democratic nomination for governor on an ill-thought out program of immediate socialist demands.

Thomas declared that Sinclair was capitalizing on the emotions of men rather than sticking with Socialism and proceeding in a logical; scientific fashion. Additionally, he noted that while opposing Sinclair might be unpopular, the Socialists had to oppose EPIC, for "only by opposing it can Socialists be in a position to avoid blame for his failure." The National Executive Committee of the Socialist Party reiterated Thomas' stance with the issuance of a statement which read: "He is not a Socialist and he is not supported by the Socialist Party." 210 Most importantly, Thomas was upset with Sinclair because he did not hold "aloft the banner of Socialism." He criticized Sinclair, saying:

For you to haul that (Socialist banner) down is a loss to us not to be compensated by any of the dubious gains of your program even in the doubtful event of your being in a position to attempt it. Words are symbols. You alone, or with the help of a certain number of California voters, cannot make the word Democratic a symbol for Socialism.

Thomas feared that because of Sinclair's charisma upon Californians, America would become a fascist society. Recalling the efforts of semiSocialist movements, such as the Non-Partisan League, which attempted

${ }^{210}$ B.K. Johnpol1, Pacifist's Progress: Norman Thomas and the Decline of American Socialism (Chicago: Quadrangle, 1970), p. 135; Hyink, Brown, and Thacker, Politics and Government in California, p. 68; Johnpo11, Pacifist's Progress: Norman Thomas and the Decline of American Socialism, pp. 135-37; New York Times, September 3, 1934, p. 14. 
to gain control of the major parties, Thomas asked Sinclair: "Have they ever succeeded?" 211

In Ca1ifornia, a state which Norman Thomas described as "cursed by reaction and industrial feudalism," Sinclair did receive the support of many left wing party activists. Not all Socialists denounced. Sinclair. Jerry Voorhis, a youthful Socialist and future Congressman, the pamphleteex Waltex Thomas Mills, the left wing organizer Kate O'Hare, and former Berkeley Mayor J. Still wilson, believed in Sinclair and his plan. To most.California Socialists, tired of pointless campaigning, Sinclair's EPIC plan offered the prospect of victory. ${ }^{212}$

\section{COMMUNIST PARTY}

The Communist Party of California also denounced the candidacy of Sinclair. The party regularly distributed anti-Sinclair literature at Sinclair rallies and the Western Worker, the official west coast organ of the Communist Party, criticized the EPIC plan calling it, in a derogatory reference to the National Recovery Administration: "blue eagle," "another addled egg from the blue buzzard's nest." 213 California

Communists further denounced Sinclair as a "social Fascist," and "the

${ }^{211}$ Norman Thomas, "American Socialism's Weakest Link," The World Tomorrow, April 12, 1934, p. 182; B.K. Johnpol1, Pacifist's Progress: Norman Thomas and the Decline of American Socialism (Chicago: Quadrangle, 1970), p. 135.

${ }^{212}$ New York Times, November 7, 1934 , p. 2; B.K. Johnpoll, Pacifist's Progress: Norman Thomas and the Decline of American Socialism (Chicago: Quadrangle, 1970), p. 136.

213 Singer; "Upton Sinclair and the California Gubernatorial Campaign of 1934," p. 388 
Fuehrer of Altadena." In addition the Communist Party suggested that Sinclair was more of an "insidious threat to the proletariat than the Republican candidates since the latter were easily identifiable as 'reactionaries' whereas Sinclair might easily deceive the workers into believing that he was a 'liberal."'214 Robert Minor, a Communist Party member, further stated that the EPIC proposals "are the most reactionary that have been made by any politician during the economic crisis." In fact, Minor believed Sinclair's scheme to be the most "cold bloodedly pro-capitalist and reactionary proposals... offered by any candidate in any election in the United States in a decade." 215

Criticism of Sinclair did not remain within the boundaries of the continental United States. In the Soviet Union, the official Communist Party paper, Ivestia, as quoted by the Living Age, had this to say of EPIC:

Epic Upton has raised a cloud of 'Epicdust' with his manifesto, which might cloud the view of some people at the very moment when the American intelligence is so much in need of clear vision. Of course, this 'Epic' cloud will dissove itself. The 'Epic' foundation will dry up. But naivete of Sinclair should be punished... We hope that he will be elected governor of California. 216

According to Kar1 Radek, a leading Soviet official, the Democratic nominee was "stepping along the path of barren Fascism." The American

${ }^{214}$ Luther Whiteman and Samuel Lewis, Glory Roads: The Psychological State of California (New York: Thomas Y. Crowell, 1936), pp. 228, 383 .

${ }^{215}$ E. Lyons, The Red Decade: The Classic Work on Communism in America during the 1930's (New York: Doubleday, 1945), p. 170 .

216."EPIC Upton," Living Age, March 1934, p. 180. 
Communist Party. also denounced Sinclair as a "social Fascist;" a term used for anyone who advocated compromise with capitalism; while a Communist leaflet quoted Lenin's description of Sinclair as "an emotional Socialist without theorectical grounding. "217

Years after the election, Steve Murdock, a writer for the People's World, a west coast communist newspaper, indicated that the Communist Party had made a mistake in denouncing Sinclair. According to Murdock, Sinclair was the only viable candidate whose ideas were not total anathema to the party. 218

\section{SUMMARY}

By November 6 not a single member of Sinclair's own party with an established statewide or national reputation endorsed him. Local and state Democratic leaders denounced Sinclair and predicted "a genera1 stampede from the fellow who is now leading." 219 The national administration maintained a policy of strict neutrality, which they defined as, "Say nothing, Do nothing." The President was of the opinion that "Sinclair will win if he stages an orderly, common sense campaign, but will be beaten if he makes a fool of himself." 220

The Sinclair threat also caused the Republican Party to launch one

${ }^{217}$ Singer, "Upton Sinclair and the Califormia Gubernatorial Campaign of $1934, "$ pp. 388, 419.

${ }^{218}$ Steve Murdock, "California Communists--their Years of Power," Science and Society, XXXIV (Winter, 1970), 481.

219 Larson, "EPIC Campaign of 1934," p. 147.

${ }^{220}$ Roosevelt, F.D.R.: His Personal Letters, p. 164. 
of the most intensive propaganda campaigns ever waged in American state politics. 221 Governor Merriam weakend Sinclair's base of support by promising that his victory would:be "a bipartisan triumph and in no sense a repudiation of the New Deal." He also declared that the Democrats would "not be forgotten" if he were re-elected." Much of the Democcratic platform was neutralized with the passage of numerous measures during the special session of the California legislature, called into session by Merriam in September. Merriam believed, "If I win, I know it will be by virtue of Democratic as well as Republican votes" and I will give "consideration to candidates of al parties" in making future appointments. 222

Socialist and Communist Party leaders alike repudiated the EPIC movement from its conception. Although EPIC was a semi-Socialist plan, EPIC was denounced by party officials who predicted that the Sinclair candidacy would ruin the Socialist Party in California. By September 1934, the California Socialist Party was in a state of collapse. "Los Angeles has practically no movement to the left," a party leader wrote Norman Thomas. According to Milen Dempster, "we have lost many really fine comrades" and unions which previously helped "Socialist candidates now threw all theix resources into the Sinclair campaign." 223 Anti-. Sinclair literature was distributed at Sinclair rallies and Communist leaders in both the United States and the Soviet Union publicly

${ }^{221}$ Larsen, "EPIC Campaign of 1934," p. 147.

${ }^{222}$ San Francisco Chronicle, November 1, 1934, p. 1 .

${ }^{223}$ B.K. Johnpol1, Pacifist's Progress: Norman Thomas and the Decline of American Socialism (Chicago: Quadrangle, 1970), p. 137 . 
criticized EPIC. Sinclair was accused of "selling-out", and being "opportunistic". Left wing party leaders feared above all for the future security of their parties; frightened that they would be blamed for the programs and policies espoused by Sinclair. 


\section{CHAPTER V}

\section{RESULTS OF THE 1934 PRIMARY AND GENERAL ELECTIONS}

Analysis of the primary and general election returns of 1934 was obtained from the Statement of the Vote between 1928 and 1940. This statistical record was compiled by Secretary of State Frank C. Jordan. Percentages were computed by the researcher, except as otherwise indicated.

For the purpose of this study, Southern California has been designated as that area south of the northern boundary of San Luis Obispo, Kern and San Bernadino counties; and Northern Califormia has been designated as that area north of this line. For a graphic illustration refer to Figure 1.

\section{REGISTRATION}

The 1930's represented a period which introduced hundreds of thousands of California citizens to political activity. As Table I shows, registration in California had increased from 39.5 percent of the population in 1930 to 52.5 percent in 1934. According to Leon Harris, this increase in political activity marked the turning point in California politics. For the first time the Democrats had a majority of the registered voters, with $1,555,705$ registered Democrats to $1,430,198$ Republicans. From 20.3 percent in 1930 the party registration spiraled in 1932 to 40.2 percent of the total registrants and in 1934 surpassed 


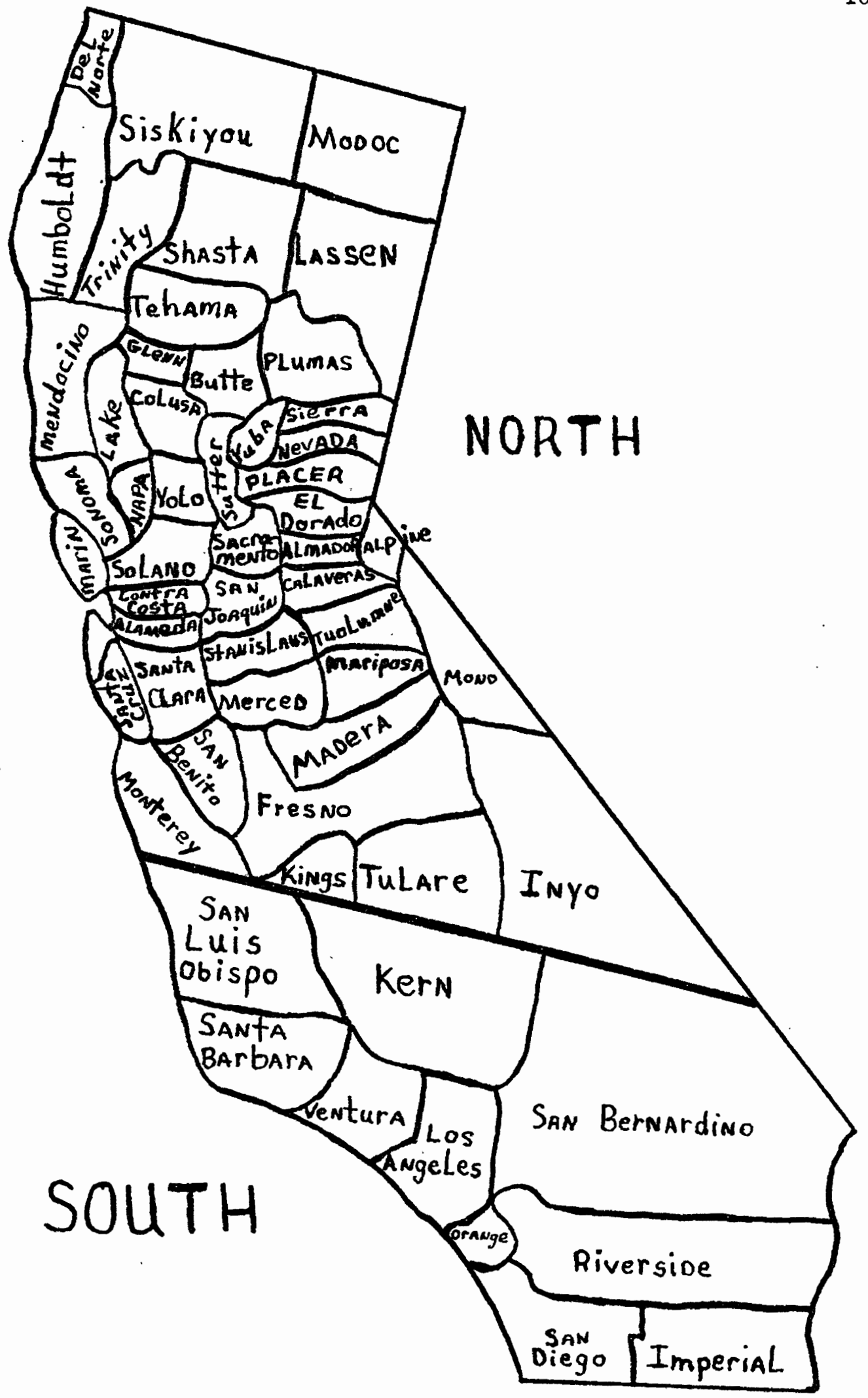

Figure 1. The counties of California. 
ฮ

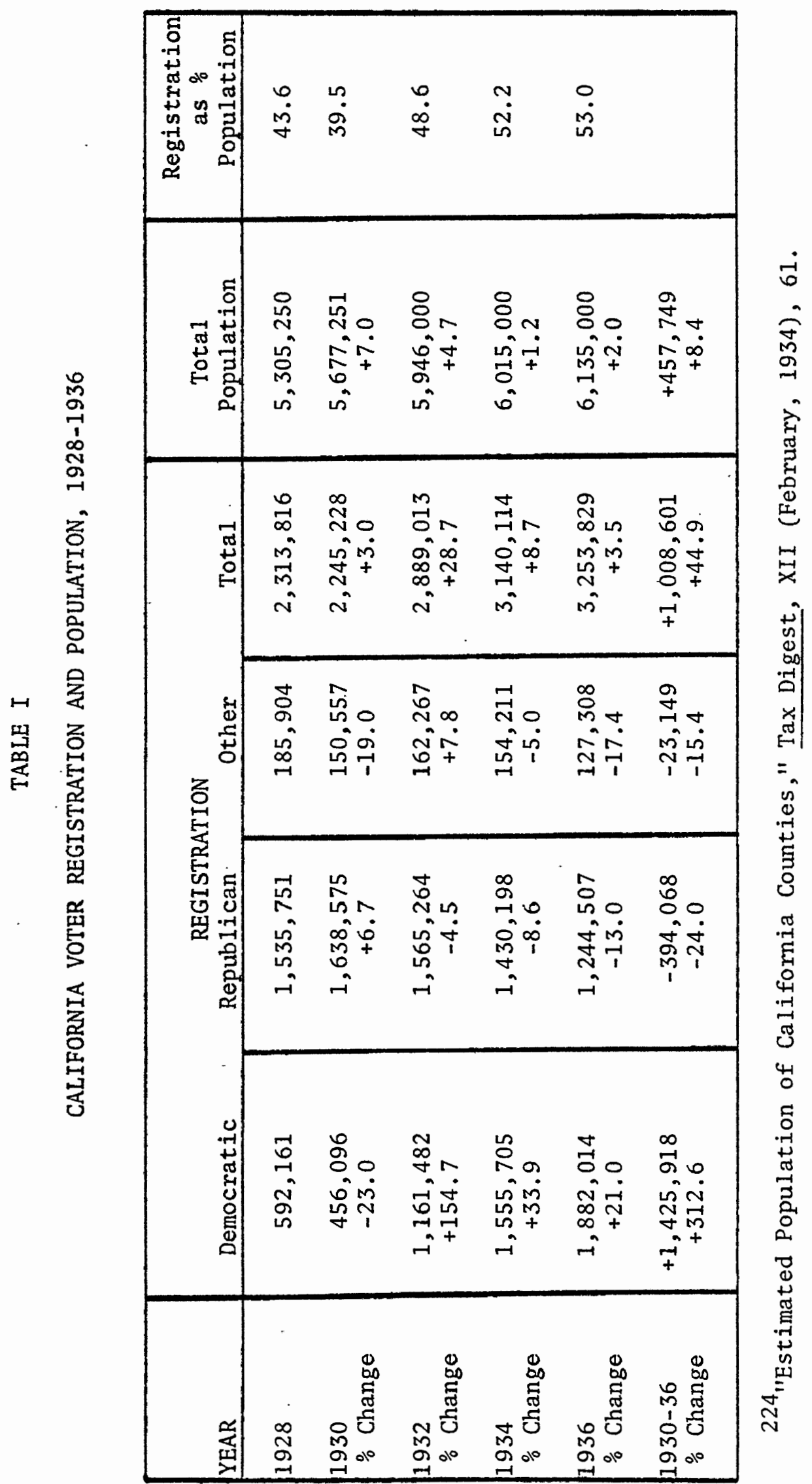


the Republican Party with 49.5 percent. Also during this period the number of actual votes cast in the Democratic primary multiplied seven times over; the Republican primary vote declined by one-third. ${ }^{225}$

The Democratic transformation in the registration pattern in California occurred between 1930 and 1936. As Table II indicates, the Democratic Party added 1,425,918 registrants to its ranks, an increase of 313 percent. At the same time, the Republican Party lost 394,068 registrants, a decrease of 24 percent. In general, total registration increased 50 percent. Not until 1946 was the Republican Party able to regain its numerical strength of $1930 .{ }^{226}$

In 1934 just under one-half of all registered voters in California were Democrats, 29.5 percent. Republicans represented 45.5 percent of all registered voters, a significant decrease from the 54.1 percent popularity it held in $1932 .^{227}$ The Democratic registration of the whole state gave the party a 75,285 majority over the Republicans. In Los Angeles County the Democrats had registered 674,434, for the August primary, exceeding the Republicans by 138,223.

For the first time in forty years the Democratic registration exceeded that of the Republicans for a primary election. California in 1934, with a population of $6,015,000$, registered $3,062,317$ or 52.2 percent of its residents for the August 28 primary. Los Angeles County

225 Michael Rogin and John L. Shover, Political Change in California: Critical Elections and Social Movements; 1890-1966 (Westport, Conn.: Greenwood Pub., 1970), p. 112.

${ }^{226}$ Lee, California Votes, $1928-60$, p. 28.

227 Johnpo11, Pacifist's Progress: " Norman Thomas and the Decline of American Socialism, pp. 1-2. 


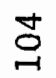

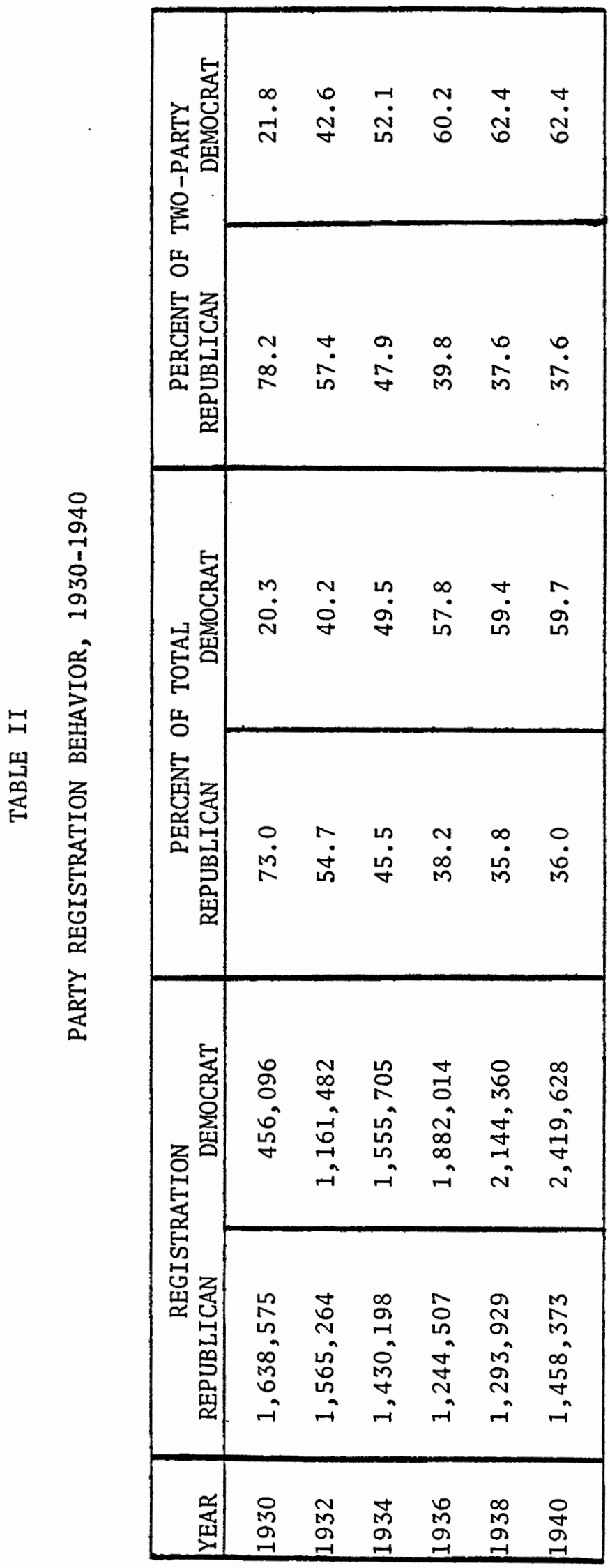


alone registered $1,301,093$ voters or 42.5 percent of the 58 county state total. San Franciscoflameda counties together registered 564,245 voters or 18.4 percent of the state total. The Democratic registration of the whole state gave the Democrats a 75,285 majority over the Republicans. Of the 3,062,317 registrants, 1,817,027 votes were cast, 59 percent of participation by the eligible voters. The Republicans had a 62 percent rate of voter participation, while the Democrats claimed 55 percent.

Registration for the November 6 election was 77,797 greater than the primaries of August; 251,101 larger than that for the November general election of 1932 and 894,886 more than that of the general election of November 1930. In the 10 Southern California counties 77.8 percent of the registered voters went to the polls, which represented 55 percent of the state vote. The greatest voter registration centered in Los Angeles County with a total of $1,305,527$ or 53.9 percent of the state's total registered voters. San Francisco-Alameda counties were second with a combined total of 580,020 registered voters, representing 18.5 percent of the state total. The general election showed a 75 percent voter participation with a total of $2,360,916$ votes cast. The 48 Northern California counties recorded a 71.3 percent rate of voter participation which represented 45 percent of the state vote. In the 1934 general election 606 of every 1,000 eligible voters cast ballots for governor compared to 445 in 1922, 420 in 1926 and 410 in $1930 .{ }^{228}$

228

Rogin and Shover, Political Change in California: Critical Elections and Social Movements, 1890-1966, p. 134. 


\section{PRIMARY ELECTION}

In examination of the primary vote of August 28,1934 , the vote of Raymond Haight, Frank F. Merriam, John R. Quinn and C.C. Young will be considered on the Republican ticket; and George Cree1, Upton Sinclair, Justus S. Warde11, Milton K. Young, Forrest E. Dowey, William H. Evans, Zachary T. Malaby, William J. McNichols, and James E. Waddell will be considered on the Democratic ticket. Statistical analysis will not be provided on candidates of the Socialist, Communist, Progressive or Commonwealth tickets. Information on the candidates of these parties can be obtained in Appendix B.

There were 872,824 votes cast on the Republican ballot. All told 44 percent of the total vote was cast in Southern California. Frank E. Merriam owed his Republican candidacy for governor to the voters of Southern California, while Northern California, with 56 percent of the Republican vote, divided its vote among all the candidates so that none could claim a majority in that area.

Governor Merriam won a plurality of the Republican votes with 346,329 votes, 42.3 percent of the total in the Republican primary. He ran 114,898 votes ahead of his nearest competitor, C.C. Young. Merriam captured Southern California's Republican ticket with 207,282 votes, 54 percent of the total Southern California Republican vote. Merriam's southland victory contributed to 59 percent of his total vote. In Southern California, Merriam captured every county except Kern and San Luis Obispo. Los Angeles County alone contributed approximately 42 percent of his total vote. In Northern California, however, his vote 
was 139,047 , only 28 percent of the Republican vote of the area. Merriam carried the counties of Inyo, Mono, Alpine, Monterey, San Benito, Santa Clara, Santa Cruz, Solano, Sonoma, Mendd́cino, Humboldt, De1 Norte, Tehama, and Shasta. Merriam's total vote of 346,329 represented approximately 39 percent of the total Republican vote of California. C.C. Young, former governor of California, received 288,106 Republican votes, second only to Merriam. Unlike Merriam he only received 59,052 votes in Southern California, 15 percent of the total vote of that area. Young did, however, carry the county of San Luis Obispo. In Northern California Young accumulated his largest vote. He received 229,054 votes, 80 percent of his total vote and approximately 46 percent of the total Republican vote in Northern California. Young carried the counties of Merced, Mariposa, Tuolumne, Stanislaus, San Joaquin, Yuba, Butte, G1enn, Modoc, Lassen, Lake, Napa, Marin, San Francisco, San Mateo, Alameda, Contra Costa, and Yolo.

John R. Quinn, a progressive Republican, was third in the race with a total vote of 153,412 . In Southern California he received 53,671 votes, 14 percent of the total vote of the area. Of the Southern California counties, Quinn claimed only Kern. He received 99,741 votes in Northern California, 65 percent of his total and approximately 22 percent of the Northern California area vote. Quinn's greatest strength came from the lower San Joaquin Valley counties of Tulare, Kings, Fresno, and Madera, along with upper Northern California counties of Plumas, Sierra, Colusa, Trinity, and Siskiyou.

Raymond Haight, a Progressive who cross filed on the Republican ticket, received a total of 84,977 votes in the Republican primary 
election. Of this total 64,847 of the votes were received in Southern California, 76 percent of his total vote and 17 percent of the vote of the area. He accumulated 20,130. votes in Northern California, only 4 percent of the total vote of the area. While Haight was unsuccessful in the Republican primary, he won on both the Commonwea1th and Progressive Party tickets as expected with 2,421 and 1,344 votes respectively. Merriam's primary victory. was the result of two factors. First, Young and Quinn split the Republican vote in Northern California; together they received 68 percent of that area's vote to Merriam's 28 percent. Second, Merriam was elected as a candidate by Southern California, Los Angeles County in particular, even though he received only 39 percent of the total Republican vote. In Figure 2, the distribution of Republican primary votes is provided.

Sinclair, polling the highest vote ever given to a Democrat in a primary in California, received 436,220 votes out of a total of 844,117 in the Democratic primary, a clear majority of 51.7 percent. Of the 814,900 votes cast in the primary, 57 percent were cast in Southern California. While Southern California was important to Merriam's victory, it was even more so to Sinclair. From the 10 southern counties Sinclair received 300,749 votes, more than the total vote of any other Democratic candidate. This vote comprised 68.9 percent of Sinclair's total vote and 64 percent of the Democratic vote of Southern California. With 8 rivals, Sinclair obtained a margin of 148,094 votes over his nearest opponent. He carried only 25 of the 58 counties, including all the counties of Southern California except Imperial. Los Angeles County alone gave Sinclair 238,308 votes, representing 54.6 percent of 


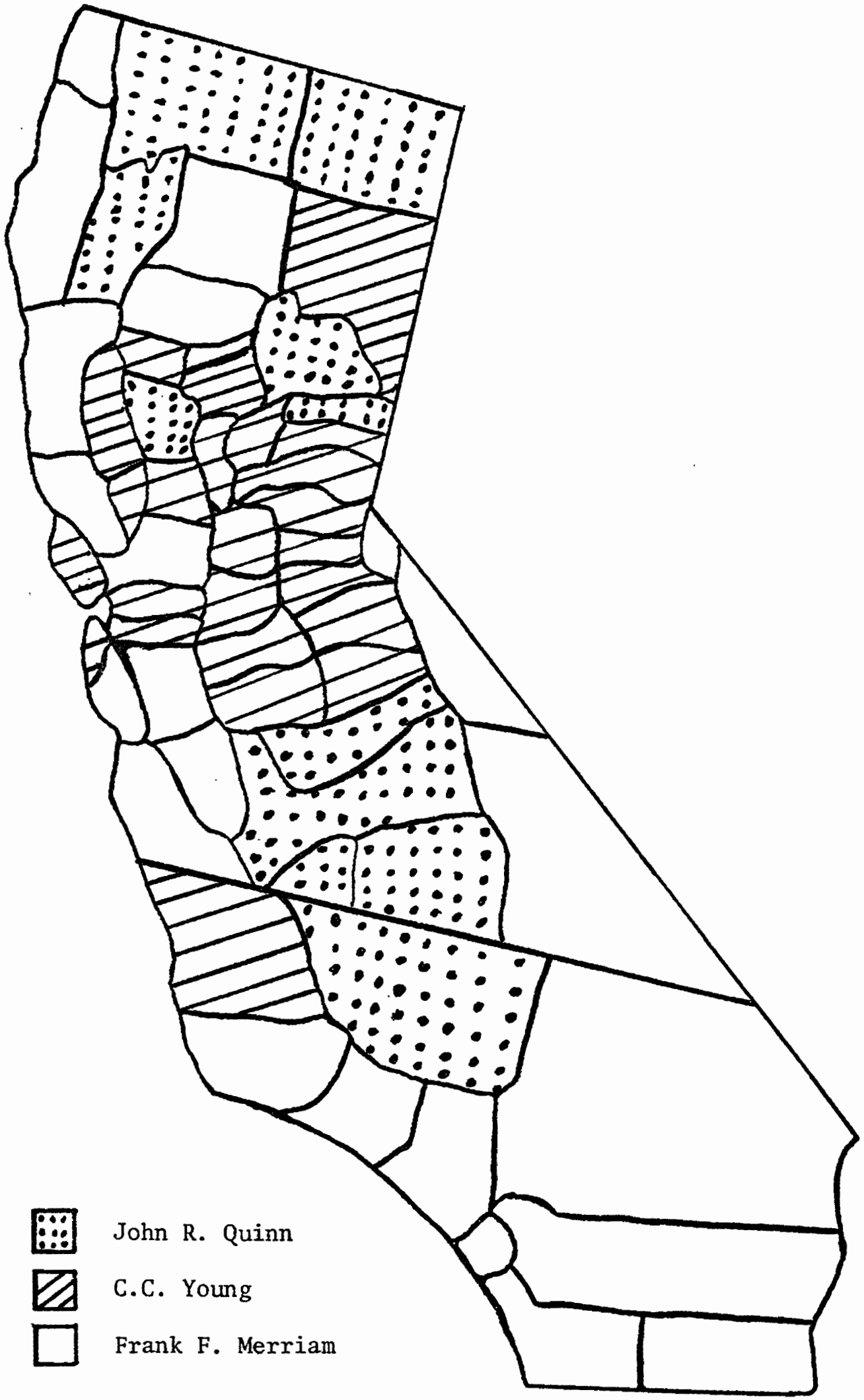

Figure 2. Distribution of Republican primary votes. 
his total vote. Los Angeles County also contributed 7,958 write-in votes in the Republican primary for Sinclair. In the other 57 counties, Creel led Sinclair by 7,237 votes. In Northern California Sinclair received 135,471 votes, 39 percent of the Democratic vote of Northern California. He carried the counties of De1 Norte, Humboldt, Trinity, Butte, Plumas, Lake, Napa, Inyo, Monterey, Mariposa, Tuolumne, Amador, San Joaquin, Contra Costa, and Alameda. Figure 3 illustrates the distribution of Democratic primary votes by the counties. George Cree1, Sinclair's closest opposition, received 288,106 votes, 34.1 percent of the total Democratic votes cast. In Southern California he received 127,839 votes, or 27 percent of the total Democratic vote of that area. The only county Creel carried was Imperial. In Northern California, Creel received the greatest number of votes among the Democratic candidates with $16,267,56$ percent of his total vote and 46 percent of the total Democratic votes cast in that area. Creel carried 32 Northern California counties, those that Sinclair did not. Although Creel took 64 percent of the Northern California vote, he could not surpass Sinclair's margin in Southern California. Creel observed:
Northern California offered no problem for here hard headed, hard working native sons and daughters were in a majority, but when I crossed the Tehachapi into the Southern California, it was like plunging into darkest Africa without gun bearers. 229

Creel's victory in Northern California, however, was not large enough to compensate for Sinclair's victory in Southern California.

${ }^{229}$ Creel, Rebel at Large, Recollections of Fifty Crowded Years, pp. 285-86. 


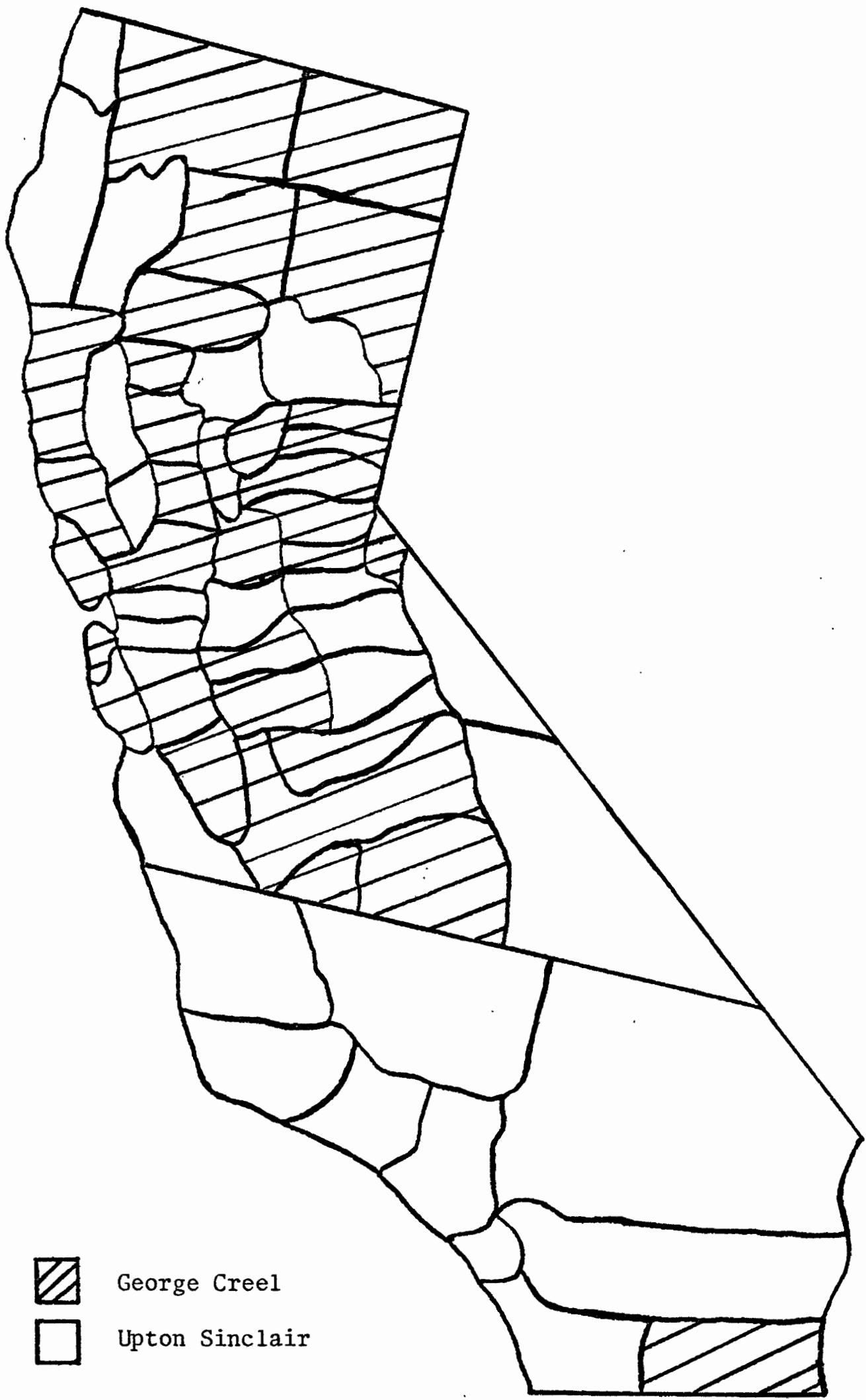

Figure 3: Distribution of Democratic primary votes. 
Justus Wardel1 received only 48,965 votes, or 5.7 percent of the party vote. The Southern California vote represented 18,635 of Wardell's total, or 4 percent of the vote of that area. In Northern California he received 30,330 votes, only 8 percent of the areas Democratic vote.

Milton Young, former 1930 Democratic gubernatorial election standard bearer, received 41,609 Democratic votes. Of those votes 19,074 came from Southern California, or 5 percent of the total Democratic vote of the area. He received 22,535 votes in the northern part of the state, approximately 7 percent of the total Democratic vote of the area. Neither Wardell nor Young captured any counties.

Sinclair, as did Merriam, owed his election to the voters of Southern California, especially Los Angeles County. While Southern California gave Sinclair 68 percent of his total vote, Los Angeles County alone contributed 55 percent of his total vote. The Southern California landslide enabled Sinclair to capture the Democratic primary with 53 percent of the total Democratic vote.

In addition to Cree1, Sinclair, Wardell and Young, five other Democratic candidates received a scattering of votes. These individuals included: Forrest E. Dowey, a Los Angeles physician; William H. Evans, a Culver City businessman; Zachary T. Malaby, former state chairman of the Democratic State Central Committee; William J. McNichols, a Hollywood lawyer; and James E. Wadde11, a businessman. Not one of these candidates received enough votes to carry a single county in the state. Together they contributed 14,011 of the total Democratic votes cast in Northern California, and 13,154 of the votes in Southern California. In both Northern and Southern California James E. Waddell received the greatest 
number of votes. Northern California preferred Dowey $(2,330)$ next to Waddell, followed by Malaby $(1,999)$, Evans $(1,431)$ and McNichols $(1,213)$. In Southern California, Democratic voters expressed their preference for Malaby $(2,428)$, McNichols $(2,398)$, Dowey $(1,899)$, and then Evans (995).

Of the two parties, the Republicans had the greater proportion of voter participation. With a registration of $1,418,826$ and a vote of 872,824 , the Republicans could claim 62 percent participation while the Democrats, with a registration of $1,494,111$ and a vote of 814,900 , could claim 55 percent participation.

The Republican and Democratic Party centers of strength differed. While in Southern California 57 percent of all Democratic votes were cast, the Republicans cast only 44 percent of the votes in the area. Political analysts, as a result of the primary elections, predicted that the Democrats would probably carry Southern California in the genera1 election while the Republicans carried Northern California. Thus the Democratic Party had the advantage to win the general election because of its control of Southern California.

Summary

Sinclair's primary victory resulted from many factors. Unlike Merriam, EPIC offered an immediate statewide solution to California's economic and social problems. Merriam stated that he intended to end problems such as unemployment through national programs and funds. Sinclair's EPIC program was especially appealing to Southern California, where because of economic turmoil and social instability, 70 percent of the state's unemployed resided. Sinclair referred to his nomination as 
a "political miracle," stating to the public:

I did not make this victory, it has been made by the people of our state. It is a spontaneous movement which has spread all over the state by the unpaid labors of tens of thousands of devoted workers... in less than a year they have built a movement which has caxried a state of more than six million population. It has been called a political miracle and the rest of the states will wish to known what it means. 230

Moreover, due to the ineffectiveness of the Republican Party to solve the crises of the depression as expediently as the public desired, a significant number of California's new residents registered as Democrats. The July 11 edition of the Los Angeles Times commented on Sinclair's growing strength, attributing to:

...the new 'Democrats', for the most part have affiliated with a political party for the first time in order to vote for Upton Sinclair for governor of California... That this situation is unwelcome to the real adherents and leaders of the Democratic Party is recognized by every politically informed man and woman in the state. That it may have grave and far-reaching results is not open to challenge. 231

As statistics indicated in Chapter II, the unemployed and recent residents of California played a major role in the nomination of. Upton Sinclair. EPIC promised a guaranteed wage and employment.

In addition Sinclair's victory indicated EPIC's popularity with special classes of individuals and special "cause" oriented groups. Many groups related to Sinclair because he was not "much a party man", but was

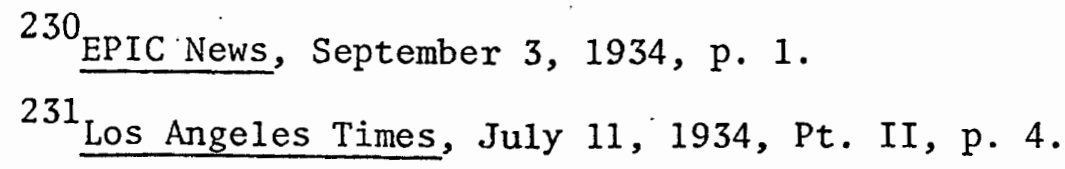


"more interested in spreading.ideas..." 232 While Sinclair's victory resulted from the support of the unemployed, self-help cooperatives; technocracy organizations, and Utopian Society, Sinclair was also endorsed by such groups as the "Coin" Harvey.'s Inflationists Liberty Party, the Los Angeles Society: for Adult Blind, the California Progressive Club, and John Dewey Study Clubs of the League for Independent Political Action. 233 Another source of support came from organized labor. After several locals of the railroad brotherhoods endorsed Sinclair at their state convention by a vote of three to one, Sinclair was endorsed by other labor groups. The EPIC ranks claim that Sinclair's greatest strength came from working-class neighborhoods was probably accurate. 234

of the five candidates competing for the governship of California, Sinclair and Merriam were the major contenders. Sinclair presented a radical formula which promised to provide economic security. He based his program on the belief that the old order needed to be changed fundamentally in order to solve the economic crisis. Through the resurgence of the Democratic Party, Sinclair intended to solve the crisis through the partial socialization of the economy. Sinclair urged all Californians to join him in "driving reaction from the state and setting up a government in the interest of al1." 235 Merriam, however, accepted

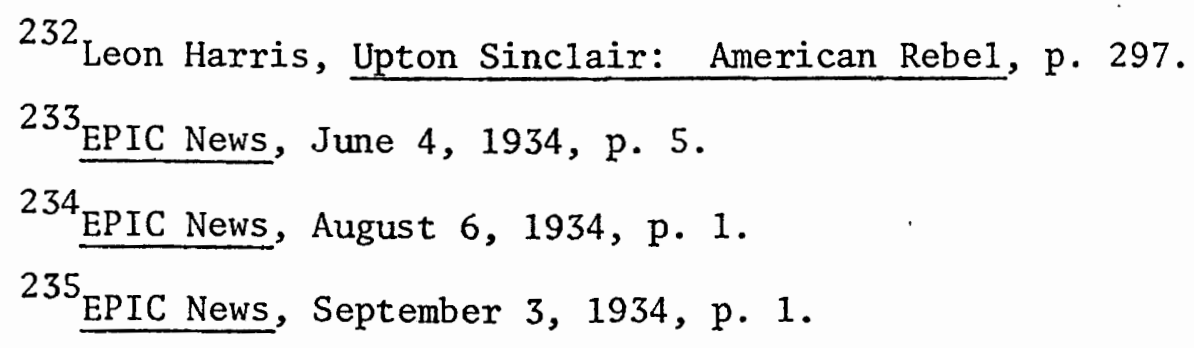

${ }^{232}$ Leon Harris, Upton Sinclair: American Rebel, p. 297. ${ }^{233}$ EPIC News, June 4, 1934, p. 5. ${ }^{234}$ EPIC News, August 6, 1934, p. 1. ${ }^{235}$ EPIC News, September 3, 1934, p. 1. 
the traditional order of institutions, but recognized that some adjustments in it, primarily on the national level, had to be made. He advocated a continuation of the traditional relief methods of direct aid and work relief, and some state measures to increase security. The major issues of the ensuing campaign to be decided by the voters was the method to provide economic security.

\section{GENERAL ELECTION}

Voters turned out in record numbers on November 6 . The total vote cast was $2,330,132$; it exceeded by 30,784 the number cast in the 1932 presidental election, and by 916,044 the total of the previous gubernatorial campaign in 1930. Of the total registered voters, 3,104,114, 75.2 percent, went to the polls. While voting figures include all parties, this thesis will only be concerned with that of the Republican, Democratic and Progressive parties with a combined total of 2,320,676. Voter interest was greater in Southern California where the heaviest unemployed and migrant population resided. Of the registered voters in the 10 southern counties, which contained 53 percent of the registered voters, 77.8 percent cast votes. Los Angeles County alone accounted for 41 percent of the state vote. In the northern counties, 71.3 percent of the registered voters went to the polls. More complete data on the regional distribution of votes for governor is available in Table III.

The results brought a severe defeat to the EPIC movement. Sinclair received 37.3 percent of the total votes cast for governor; Merriam received a plurality with a near majority of the votes, with 48.9 percent of the votes; and Haight received 12.9 percent of the votes. Together 
these three candidates drew 99.1 percent of the vote for governor. Sinclair's 879,000 total was only 4.4 percent greater than the Democratic primary vote for all candidates, while Merriam's $1,138,620$ was a 29.1 percent increase from the August primary. Out of 10,721 precincts in the state, 6,839 gave Merriam 594,955, Sinclair 481,554, and Haight 158,674 votes. Figure 4 illustrates the distribution of general election votes throughout the counties of California.

\section{TABLE III}

REGIONAL DISTRIBUTION OF THE VOTE FOR GOVERNOR, NOVEMBER 6, 1934

\begin{tabular}{lccc}
\hline \multicolumn{1}{c}{ Area } & $\begin{array}{c}\text { REPUBLICAN } \\
\% \text { of Vote }\end{array}$ & $\begin{array}{c}\text { DEMOCRAT } \\
\% \text { of Vote }\end{array}$ & $\begin{array}{c}\text { PROGRESSIVE } \\
\% \text { of Vote }\end{array}$ \\
\hline Northern California & 48 & 35 & 17 \\
Southern California & 49 & 40 & 7 \\
Metropolitan Areas & 48 & 39 & 13 \\
Non-Metropolitan Areas & 52 & 35 & 13 \\
Mountain Counties & 43 & 34 & 23 \\
Los Angeles County & 48 & 42 & 10 \\
San Francisco County & 51 & 39 & 10 \\
San Joaquin Valley & 39 & 32 & 29 \\
Sacramento Valley & 42 & 30 & 28 \\
California, the State & 49 & 40 & 11 \\
& & & \\
\hline
\end{tabular}

In Los Angeles County, with 45 percent of the state's voting strength, Merriam received 6 votes to every 5 received by Sinclair. In 25 of the 58 counties, Merriam led the race with a lead of 2 to 1 or better, maintaining a comfortable margin in San Francisco and Alameda counties. The race was close in the 11 remaining counties, especially 


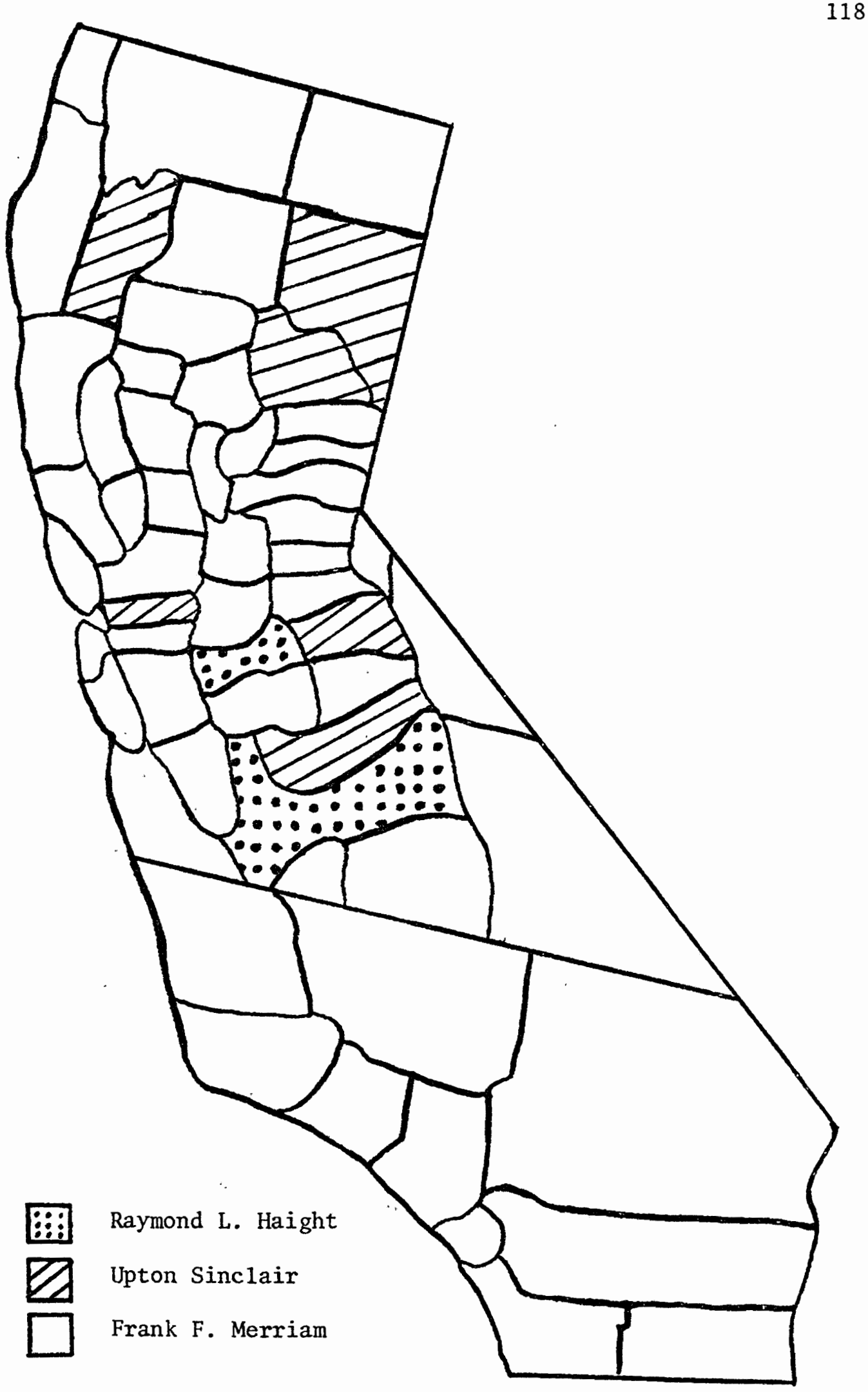

Figure 4. Distribution of general election votes. 
in Sacramento and San Diego.

The Republican candidate, Frank Merriam, received 1,138,620 votes, with a majority in 25 and a plurality in 24 counties. His highest percentage was in remote Alpine County which gave him 82.9 percent of its votes. In San Francisco and Alameda counties, he polled 50.7 percent and 52.7 percent of the total vote cast, 12 and 15 percent respectively more than did Sinclair. He also carried Northern California with 505,249 votes, 48 percent of the total votes cast in that area. He carried every county except Trinity, Lassen, Plumas, Contra Costa, Stanislaus, Tuolume, Madera and Fresno. Southern California, where he carried all the counties, 7 by majority and 3 by a plurality, gave him 633,370 or 56.5 percent of his total. Los Angeles County, which was his home as well as that of Sinclair, favored Merriam with 47.5 percent of its vote, 5.5 percent higher than his opponent, and 40 percent of his total vote. While Merriam was not a majority governor, he did capture the votes of both Northern and Southern California.

Upton Sinclair, Democratic candidate, received a total of 879,537 votes. Sinclair carried by a plurality only 6 of the 58 counties: Contra Costa, Lassen, Madera, Plumas, Trinity, and Tuolumne, all in Northern California. He drew. his heaviest percentage of the vote in some of these counties, getting 45.7 percent in Contra Costa, 44.19 percent in both Trinity and Tuolumne, and 44.7 percent in Lassen. In the heavily populated San Francisco and Alameda counties he got a 38.7 percent and 37.7 percent respectively. Northern California also contributed to 372,605 votes, or 35 percent of the votes cast in that area. Although Sinclair was relatively stronger in some of the northern counties, his 
vote was heaviest in Southerm California. The 10 southern counties provided 516,922 or 58.7 percent of his total vote and 40 percent of his Southern California total. Los Angeles city, the center of the movement, alone provided 43.18 percent of his total. Despite Sinclair's popularity in the south, he did not carry a single southern county. Haight, in contrast to the other two candidates, was stronger in the north. Statewide the Progressive candidate received a total of 302,519 votes. He obtained a plurality in 3 northern counties--E1 Dorado, Fresno and Stanislaus--and was. weakest in the south where he got only 135,798 or 44.9 percent of his vote and 11 percent of the area vote. In Northern Califormia Haight obtained 166,721 votes, 16 percent of the votes cast in that area. Northem support centered outside the San Francisco Bay area and in the San Joaquin Valley. In addition to those counties carried by plurality, Haight won more than one-third of the votes in Yolo and Sacramento. The fact that he drew only 12.9 percent of the total vote was a possible indication of the weakness of moderate sentiment in California as well as a sign of his weak organization.

$\underline{\text { Summary }}$

The election statistics do not indicate who voted for Sinclair or why he lost the election. To ascertain the answer to these questions one must speculate. Some politicians asserted that Sinclair might have won if the election had been held the first of october. Returning from his visit in the East, Sinclair had the support of the major faction of the Democratic Party, that of Senator McAdoo. Then too, registration figures were in Sinclair's favor. After the primary election, Democratic 
registration had continued to increase from $1,494,111$ to $1,555,705$. While this increase was not as significant as the pre-primary increase of 332,629 , which exceeded the 1932 registration figures, it was still high when compared to that of the Republicans. In comparison the Republican registration figures, after the primary, increased only slightly over 11,000 , from $1,418,826$ to $1,430,198$, to the Democratic increase of 61,000. Democratic registration decreased only in the mountain county of Alpine, with marked increases in fifty-six other counties. The Republicans lost in registration in Alameda County by 7,000 registrants, in Los Angeles County by 3,000, and Merced County where they dropped 900. These were offset by small increases in other counties, especially in San Francisco. In addition to registration figures, the results of the national Democratic survey disclosed early in October a possible victory for Sinclair. 236

The data presented above do not prove that Simclair would have won had the election been held in October. The impact of the opposition is not considered above. The Republican Party did not begin its intensive campaign against Sinclair until the first week of October; reports shortly followed that Sinclair's primary strength was faltering. Even if the election had been held earlier, Sinclair's opponents would have moved up the starting point of their campaign against him. ${ }^{237}$

Additionally, it is impossible to prove whether the propaganda campaign against Sinclair actually took votes from him. Sinclair nearly

\footnotetext{
${ }^{236}$ New York Times, October 5, 1934, p. 2.

${ }^{237}$ San Francisco Chronicle, October 12, 1934, p. 7.
} 
doubled his total primary vote in the November election, finally receiving 897,537 in contrast to 446,178 . Moreover, the combined Republican primary vote for the gubernatorial candidates exceeded the Democrats by more than 28,000 . In spite of the weakening of the Republican Party in California since 1930 , it still received a greater party vote than did the Democrats. In light of this, it appeared that the general election campaign did not deflect as many votes from Sinclair as it strenghened the traditional Republican ties enough to keep the Republican vote from spliting between Merriam and Haight. The campaign also revived and inspired enthusiasm among the regular Republican membership, which may explain the increase in Republican registration after the primary election. During the period between November 1930 and November 1938, the only time an increase in Republican registration was noted was during the 1934 gubernatorial campaign. Perhaps there may have been a momentary rekindling of party loyalty in Republicans in September 1934.

One of the most perplexing problems is what motivated voters to cast their ballots as they did in 1934. While Sinclair maintained that the majority of voters were influenced by their traditional party ties, only Merriam received much of his vote from the regular party supporters. As V.O. Key, Jr. pointed out in his analysis of critical elections, voters tend to make "deeper party commitments during critical periods."238 Unlike the Democratic Party, there was no evidence of Republican

${ }^{238}$ Rogin and Shover; Political Change in California: Critical Elections and Social Movéments, $1890-1966$, p. 17. 
defection during the campaign. Instead the party leaders united solidly, although not enthusiastically, behind the relatively unpopular candidacy of Frank Merriam. The strength of the party's allegiance was indicated through the small increase in Republican registration and the abandonment of Haight by some Republicans in his organization in Merriam's favor.

Sinclair did not benefit as much from the Democratic Party vote. Many voters associated the EPIC movement and the New Deal, not as being authorized or similar in detail, but rather as having the similar goal of the welfare of the people. Sinclair's stated purpose was to bring to California its share of the New Deal, and help save California as he saw Roosevelt doing for the nation. ${ }^{239}$ Californians engaged in manual labor occupations joined the Democratic Party as the New Deal developed programs they thought to be in their interest. This view no doubt bolstered Democratic sentiments, and increased Sinclair's strength.

Some Democratic votes were lost by Sinclair because of his openness and detailed EPIC program. Unlike successful Democratic candidates, such as Franklin Roosevelt, Sinclair frightened the public during the campaign by outlining his EPIC plan to end poverty and suffering in California. Sinclair viewed Roosevelt as politically astute, seeing that he was "playing a football game, and not planning another play until he sees how the first one works." 240 Recognizing his mistake, Sinclair believed the President to be a better politician because:

He doesn't tell everything he knows and

$$
\begin{aligned}
& 239 \text { "Can Sinclair Win?," Today, October 6, 1934, p. } 20 . \\
& 240 \text { EPIC News, August 25, 1934, p. } 2 .
\end{aligned}
$$


everything he plans, and that is the way to: get elected, and apparently the way to bring about changes in a democracy. 241

Sinclair realized that his candidacy was weakened by his frankness and willingness to share his solution to the Depression with the voters.

While the majority of local, state, and national Democratic Party leaders deserted Sinclair during the campaign, Sinclair still maintained some organization support. Democratic Party regulars such as Milton $\mathrm{K}$. Young remained committed to Sinclair. Additionally, Senator McAdoo's silence during the campaign may have kept some Democrats behind Sinclair. Then too, the Statement of the Vote indicated that Sinclair benefited from a traditionally strong Progressive, Socialist, and protest vote in the northern agricultural counties where he received his heaviest vote. Out of the six counties he carried, for example, had also gone to LaFollette in $1924 .^{242}$ Luther Whiteman and Samuel Lewis attributed much of Sinclair's Northern California vote to Sheridan Downey, his running mate for lieutenant governor. Downey was extremely popular with the farmers and Grange in that area. The book Political Change in California also points out that Sinclair retained a greater percentage of support in those areas comprised primarly of "laborers, service workers, craftsmen..." in the population. The greater the number of professionals, proprietors and clerical workers within a community, the greater the falloff in Democratic support. The book attributes

$241_{\text {EPIC News, February } 11,1935, \text { p. } 1 .}$

242 The Statement of the Vote throughout the twentieth century discloses this tendency. as well as an occasionally strong Democratic vote in many of the northern counties in the mountain areas of the north and northeast. 
Sinclair's votes to a "more urban-based constituency with greater labor support and greater sympathy of welfare." 243

Defections by leaders of the Democratic Party. indicated general dissatisfaction by many party regulars. Party members probably defected because of a desire to regain their traditional control of the party, and also from fear that a Sinclair victory would discredit the national administration's New Deal program. Sinclair was primarly opposed by regular Democrats, but according to Bob Barger, they could not decide whether to support Merriam or.Haight. Conservative Democrats announced their support for Merriam, and many liberal Democrats threw their votes to Raymond Haight. Haight was supported by a coalition of young liberals, non-politicos, and moderate and liberal Democrats who opposed both Sinclaix and Merriam. 244 Haight also received the support of moderate voters who felt the major party candidates represented the extreme viewpoints. ${ }^{245}$ Many conservatives campaigned against Sinclair, afraid that:

Soviets were behind every movement in America bearing the reform label. The combination of fear and hate, of concern for the preservation of property rights and national institutions, and of political experience and financial resources was more than the Epics could overcome. 246

$243_{\text {Whiteman and Lewis, Glory Roads: The Psychological State }}$ of California, pp. 134-38.

244 Barger, "Raymond L. Haight and the Commonwealth Progressive Campaign of 1934," p. 219. p. 341 .

${ }^{245}$ Nava, California: Five Centures of Cultural Contests,

${ }^{246}$ John W. Caughey, California (New York: Prentice-Hall, $1953)$, p. 262. 
Arthur Schlesinger, Jr. attributed Merriam's support to the "declining, frightened, non-political old-American lower middle class," while Sinclair pulled from the ranks of the "alert, rising, new-immigrant lower class." 247 Many people preferred Sinclair's courage and the possibilities of his EPIC plan to the platitudes of the Republican leadership who offered little change.

In September Republicans were certain that Haight's candidacy would damage their cause, however it was conceded by most observers that his votes were taken largely from Sinclair. ${ }^{248}$ Sinclair was a stronger candidate in the general election in Southem California than in the north. Political analysts attribute part of this to the candidacy of Raymond Haight. A significant block of moderate voters, feeling Sinclair was too radical and Merriam too reactionary, cast protest votes for Haight. ${ }^{249}$, The cost to Sinclair of the Haight candidacy can also be shown by a comparison of the Democratic vote for governor with that for Sheridan Downey, the EPIC nominee for lieutenant governor, who ran against a single Republican opponent. Downey received 45 percent of the state total of votes cast, exceeding Sinclair's total by 7.2 percent. In Los Angeles, Downey bettered Sinclair by 7 percent, in San Francisco by 3 percent. However in the areas where Haight was most popular, Downey's percentage exceeded Sinclair's by 14 percent in the San Joaquin

\footnotetext{
${ }^{247}$ Schlesinger, Politics of Upheavel: The Age of Roosevelt, p. 97.

${ }^{248}$ Anderson, Voting in California, p. 19.

${ }^{249}$ Larson, "EPIC Campaign of 1934," p. 144.
} 
Valley, and 10 percent in the Sacramento Valley. ${ }^{250}$ The Haight candidacy gained potential Democratic votes.

Sinclair also benefited from "newly recruited protest Democrats," in places where the party resurgence had been most pronounced, such as Los Angeles County and Southern California in general. The 50 Northern California counties contributed 46.7 percent of the total votes cast in 1934, but accounted for 56.4 percent of the decrease in Democratic votes from 1932. Southern California supplied 53.5 percent of the total votes, but only 43.6 percent of the Democratic falloff. Los Angeles supplied 41.4 percent of the total votes, but 33.5 percent of the decrease; San Francisco, 9.6 percent of the total votes, but 12.6 percent of the Democratic falloff. 251

Non-traditional factors also affected the outcome of the November election. The influence of EPIC propaganda on the electorate was moderately effective. To many victims of the Depression, Sinclair, like Roosevelt, symbolized an end to poverty and suffering. Others viewed Sinclair as a leader of the drive against the control of the state by the business and financial interests. ${ }^{252}$ Yet more effective was the antiSinclair propaganda which undercut the EPIC movement. Such issues as the Tom Mooney case, religion, radicalism, influx of transients, flight of capital, etc., hurt Sinclair's candidacy. Franklin K. Hichborn, a

250 Harold Gosne11, Grass Root Politics: National Voting Behavior of Typical States (New York: Russel1, 1970), p. 129.

251 Ibid., p. 131 .

${ }^{252}$ Sinclair, I, Candidate for Governor: And How I got Licked, p. 199. 
critic of California politics, contended that the religious issue caused a big shift in sentiment from Sinclair in the last three weeks of the election. Another observer attributed Sinclair's defeat to businesses influencing their employees voting preferences, threatening the loss of jobs. Others cited the refusal of President Roosevelt's support. as causing EPIC's defeat. Together the above factors provided Merriam with an 11.1 percent margin of votes over Sinclair. ${ }^{253}$

During the final days of the campaign, the communities were divided sharply between the employed and unemployed. As California voters went to the polls, there was a wide spread tendency to believe that those who still had jobs were voting to protect themselves against dispossession at the hands of those who did not. Carey McWilliams cited the most critical impact of the Depression was felt in those areas with the heaviest migrant population, that of Los Angeles County and the East Bay area in Northern California. Payrolls in Los Angeles County alone declined 66.1 percent between 1929 and 1933, while San Francisco payrolls dropped but 53.5 percent over the same period. The Agricultural Statistical Service of the California Department of Agriculture reported that in 1934 there were 142 workers available for every $100 \mathrm{jobs}$, and as a result about 30 percent of the agricultural workers in the state were unemployed. ${ }^{254}$ Financial and industrial interests warned employees that a Sinclair victory would result in business closures, layoffs, and production curtailments. A Congregational clergyman summarized the situation in

\footnotetext{
253 New York Times, October 14, 1934, Pt. IV, p. 1. ${ }^{254} \mathrm{Cal}$ ifornia Emergency Relief Administration, "Economic
} Trends in California, 1929-34," pp. 9-17. 
California stating:

They are freely saying that there will be no jobs if Sinclair is elected. They are saying that the election of Sinclair will be followed by the flight of capital from California, the failure of savings banks, the destruction of life insurance values...I opened the subject with scores of porters, taxi drivers, waiters, hotel clerks, and idlers on street corners. Men without jobs spoke their mind--usually for Sinclair. Men with jobs hedged, talked with a fine show of impartiality, said nothing.

The reason for California's staggering unemployment statistics was cited as the result of a constant influx of migrants from other states. By 1934, the increasing migrant population contributed 50 percent of the total number of unemployed individuals in the state. ${ }^{255}$ The entire business climate of the state was in a condition of stagnation. 256

The primary reason for the rejection of the EPIC plan by the people was that they were not yet ready for it. Economic, social and moral reforms come slowly. People are slow at breaking away from the old order of things and accepting the new. It generally takes many years of education before individuals will go to the polls and vote for a change. A plan which comes too suddenly plays its part in starting the people into thinking about economic problems but it cannot expect to win at an election. President Roosevelt, in his address before the American Youth Congress expressed this idea of the slow growth of reform:

Don't seek or expect utopia overnight. Don't

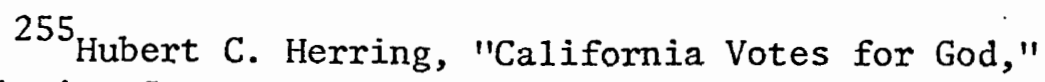
Christian Century, October 31, 1934, p. 1370.

${ }^{256}$ Larson, "EPIC Campaign of 1934," p. 127. 
seek or expect a panacea--a grand new law that will give you a handout--a guarantee of permanent renumerative occupation of your own choosing... We have not yet eliminated the terrific peaks and valleys of production and consumption. We have made definite gains...I suggest again that on social and economic matters you and $I$ are substantially in agreement as to the objective, but that there are some of you who think that objectives can be gained overnight. I don't. 257

In a final speech to the people of California, Sinclair was optimistic in his assertion that the "task of educating three million voters cannot be done in one year; but it can be done in the end, and very certainly it will be done." 258

The voters of California did not vote on the EPIC plan, which was in its immediate consequences an unemployment relief scheme. All three candidates supported state aid to the unemployed. The differences among them diminished in the course of the campaign, a1though this was not the important issue in the campaign. As discussed in Chapter III, Sinclaix's opponents succeeded in turning the campaign into one of a highly personalized nature, and took the propaganda initiative from Sinclair. It became Sinclair, for or against, and the idea of the EPIC plan became secondary to its creator in the election. What started, in August 1933, as a crusade to end poverty and to establish social justice became, by November 1934, a defense of the personal and political background of its foremost proponent. The ideas of Sinclair dropped almost completely from sight by the end of the campaign.

Late in the evening of November 6, Merriam and Sinclair broadcast

Los Angeles Times, February 11, 1934, p. 3. 258 EPIC News, November 12,1934, p. 5. 
to the nation. The Republican winner kept his promise to: J.F.T. O'Connor and declared that his victory was assured by the energetic non-partisan support of both Republicans and Democrats. It represented the adherence to sound and tried methods of government and economics. Sinclair, he stated, had tried for more than a year to create class antagonism and unrest. When his opponent had captured the Democratic nomination, party differences had been eliminated, the issue became radicalism versus Americanism. Merriam asserted: "California has rejected radicalism and socialism and indicated definite and positive adherence to sound and tested methods of government and economics." 259 This did not mean, Merriam conceded, that Sinclair had attacked the American political system, but that he had proposed to establish an experiment which closely resembled the Russian system. The defeat of Sinclairism was not a victory for "reactionaryism," Merriam declared. The people of Ca1ifornia were progressive, and because so, Merriam promised to aid the distressed by developing a program of economic rehabilitation, human welfare, and social justice. 260

On November 7 Sinclair formally conceded defeat and charged that the election had been stolen. He expressed his gratitude to the devotion of faithful workers in the "first skirmish," and vowed that "...we are preparing for the next campaign." 261 The EPIC forces could count it as a great triumph over so many millions of dollars. He was the author of

$$
\begin{aligned}
& 259 \text { Los Angeles Times, November } 7,1934, \text { p. } 1 . \\
& 260 \text { New York Times, November } 7,1934, \text { p. } 12 . \\
& 261_{\text {New York Times, November } 7,1934, \text { p. } 1 .}
\end{aligned}
$$


too many books to be a politician, he concluded. "If we had a better candidate, we might have won," Sinclair quipped. Sinclair believed that "the political Iife of this state is going to be different from now on; the reactionaries will not take everything for granted. "262

${ }^{262}$ Sinclair; I, Candidate for Governor: ' And How I. got Licked, p. 203. 


\section{CHAPTER VI}

\section{CONCLUSION: THE STGNIFICANCE OF THE EPIC MOVEMENT}

The EPIC movement was the response to an unusual set of economic, political and social circumstances created by the Great Depression in California. Many citizens had lost faith in the economic system and their political leaders. The disillusioned, impoverished and unemployed turned against the existing political and economic "status quo," and aligned themselves with a new movement which promised to restore hope. and prosperity. Out of the Depression evolved the "panacea politics" of EPIC.

The resurgent changes within the Democratic Party since 1930 made it possible for a radical such as Sinclair to win the acceptance of many Democrats. There are four reasons why Upton Sinclair was able to win the Democratic nomination in 1934. First, the Democratic Party was without strong leadership on the state level. The party, having been defeated in every election since 1896, lacked prestige and unity. Second, the 1932 victory of Franklin Roosevelt and the New Deal revived dormant Democratic activity in California. Democrats were more hopeful of a victoxy in the 1934 gubernatorial election than ever before. Democratic registration had increased markedly in the state. The EPIC program of Sinclair appealed to the new Democratic Party members who were more liberal and openminded than the old guard. Then, too, Sinclair faced weak opposition within his own party. Neither Creel nor Wardell posed a serious threat 
to Sinclair's candidacy. Finally, Sinclair had the advantage of being the first Democrat to announce hïs candidacy. As a result, Sinclair received a great deal of attention by the press and public.

Upton Sinclair was defeated not by the voters, but by the most powerful coalition ever organized to oppose a candidate in any California gubernatorial election. The opposition to Sinclair transcended party allegiances. Together, the financial and industrial interests in the state with the Republican Party and conservative Democrats defeated Sinclair. In analyzing the defeat of Upton Sinclair and his EPIC program, numerous factors played an important part. The most important of these being:

1. The charge of 'atheist' and 'defiler of religion' cited from quotations taken out of context from The Profits of Religion.

2. The communist and radical label given to Sinclair by the opposition in pamphlets, handbil1s, newspapers, and on the radio.

3. The role of the movie industry in the preparation of and distribution of newsreels which depicted scenes of transients descending on California.

4. The failure of Sinclair to obtain the endorsement of President Roosevelt and the national administration.

5. The alignment of the Republican Party with the national administration and New Deal.

6. The Literary Digest election poll that influenced the electorate a few days before the November 6 election.

7. The desertion of the Democratic Party by influential local, state, and national leaders.

8. The use of smear tactics by the opposition to confuse the issues, keeping the voters misinformed and uncertain about the EPIC plan.

Yet, even more importantly, the EPIC movement failed because of the 
rejection of the people who were unable to support such a "radical" program. As President Roosevelt asserted, economic, social and moral reforms do come slowly. Years after the election Albert Einstien, a physicist, wrote Sinclair stating: "You know...much better than $I$, that nothing annoys people more than one trying to help them..."263

EPIC was a movement within a larger movement and one which has, even though it lost the election, made many valuable contributions to California and national politics. The movement "shook the state from one end to the other and profoundly affected state elections for more than a decade. "264

Although Sinclair was defeated, EPIC did produce a forceful Democratic Party in California for the first time in many years. He reorganized the party by attracting new voters and encouraging political careers. According to Charles Van de Vander:

The 1932 campaign created the raw material for an opposition party. The EPIC campaign, two years later, solidified this raw material into the powerful potential force out of which evolved a party machinery and a party personnel. And it laid a basis for subsequent party victory. 265

EPIC sponsored candidates were elected to numerous local offices and thirty-seven EPIC Democrats were elected to the State legislature (twelve were actually pledged), forming the foundation of a new "reformist"

263 Upton Sinclair, My Lifetime in Letters (Columbia: University of Missouri Press, 1960), p. 357.

${ }^{264}$ Leon Harris, Upton Sinclair: American Rebel, p. 10.

${ }^{265}$ Charles Van de Vander, The Big Bosses (New York: Doubleday \& Co., 1944), p. 299. 
Democratic Party. Culbert L. O1son was sent to the California Senate in 1934 and went on to the governors chair in 1938. Jerry Voorhis was elected United States Congressman. Sinclair's running mate, Sheridan Downey, later went on to the United States Senate from California. Thus, a part of the philosophy and ideology of the Sinclair movement was, in part, reflected in state and national policies and legislation long after EPIC had been forgotten. EPIC chapters also survived the election and some melted into the "Ham'n Eggs" movement of 1938-1939. 266

The EPIC movement laid the basis for Culbert L. Olson's successful gubernatorial campaign of 1938. As State Senator, 01son changed the Republican Party leaders' attitudes towards the social needs of the state. Undex threat of recal1, Governor Merriam signed a new state income tax bill; he made some attempts to stop attacks on radicals and labor; he became sympathetic toward social credits, liberalism and the New Deal; and he never criticized the New Deal and thought the "ideas were from God." 267

Frightened by the thought of a Sinclair victory, the State legislature in 1934 transferred almost all state positions under the Civil Service. Except for the replacements and appointments to new offices, the governor could make only a few appointments from some 30,000 positions. The result to California politics has been to make it

${ }^{266}$ Carey McWilliams, Southern California 'Country (New York:

Due11, Sloan and Pearce, 1946), p. 134; Rogin.and Shover, Political Change in Califomia: Critical Elections and Social Movements, 1890-1966, p. 333 .

267 Whiteman and Lewis, Glory Roads: The Psychological State of California, p. 244. 
almost impossible for any new governor to pay party patronage other than the support he can obtain from his party and other groups. ${ }^{268}$

In spite of the bitter fractionalism and its set back in the 1934 gubernatorial contest, the Democratic Party continued to rise in California. In the legislature, the Democrats increased in strength until they had a clear majority of the assembly (forty-seven out of eighty) at the 1937 session and were able to elect as Speaker, William Moseley Jones of Montibe11o. The State Senate remained Republican, though the Democratic minority rose to sixteen out of forty at the 1937 session. Only four Republican Congressmen out of twenty were elected in 1936 to the California delegation to the House of Representatives, and President Roosevelt carried the state by a majority of 900,000 votes that year. 269

One of the most significant results of the EPIC crusade, which reached far into the political future, was the effective showing made by the public relations and advertising agency of Whitaker and Baxter. This agency, along with others, demonstrated its ability to shape and mold public opinion. Since the 1934 campaign the advertising business has played an important role in state and national politics.

Then, too, EPIC forced the state officials to do more to relieve depression suffering. It also helped to bring about pension action on part of the state. In bringing this about, the EPIC movement helped to develop a sense of awareness of social problems that has resulted in more and more legislation in the public interest during the years that have

${ }^{268}$ Carey McWilliams, California: The Great Exception

(New York: Current Books, 1949), p. 182.

269 Robert E. Burke, 01son's New Deal for California

(Los Angeles: University of California, 1953), p. 5. 
followed. "People wanted to feel secure at the very least," said.A.P. Giannini, who saw the problem as a.lesson in simple economics; "proper housing, good food, good clothing and provisions for old age are all requisites of prosperity." 270 Sinclair and the EPIC movement provided a means, which was in harmony with the American democratic tradition, through which the protest of thousands suffering from the Depression could be heard.

The EPIC crusade also contributed to a leftward pressure on the New Deal. While the Liberty League accused Roosevelt of having taken the nation down the Socialistic path, Sinclair's followers were claiming that the New Deal had not gone far enough. 271 Franklin Roosevelt found. himself in the middle, watchful and opportunistic. As one observer noted:

We believe that $\mathrm{Mr}$. Sinclair is correct in believing that, as the President finds the middle ground to be disappearing, he will move leftward.

Thus according to Leon Harris:

The EPIC campaign...left behind a ferment of local radicalism not unlike that stirred by Floyd Olson and the La Follettes--a new popular militancy, fairly loyal to Roosevelt and the Democratic Party but constituting a leftward pressure on the New Deal. It was committed to a thesis of American exceptionalism... 272

270 Marquis James and Bessie James, Biography of a Bank: The Story of the Bank of America, N.T. \& S.A. (New York: Harper and Bros., 1954), p. 432 .

${ }^{271}$ Otis Graham, New Deal: The Critical Issues (Boston: Little, Brown \& Co., 1971), p. 187 .

${ }^{272}$ Leon Harris, Upton Sinclair: American Rebel, pp. 12, 318. 
Sinclair pushed a major part of the electorate to the left and activated thousands of people who had never before been politically active. ${ }^{273}$

As for the lasting value of the EPIC experiment, Carey McWilliams came closest to pointing out the most important single contribution when he said that EPIC was "one of the most successful mass education, experiments ever performed in the United States."274. According to Sinclair after the election:

One thing, the all important thing, our EPIC movement provided; the reserves of initiative and idealism which are in our people... And we have proved that the people can be taught and will act in their own behalf. I have seen them in action, and I will carry the memory of it to my dying day. 275

Sinclair espoused the economics of capitalism from one end of the state to the other. More people were made conscious of pressing social and economic problems of our society than at any other single time in California history. For the first time, organized labor in Southern California became a potentially active organization. During the campaign, there developed a labor-Iiberal political force that has been active in Southern California ever since the endorsement of Sinclair by the American Federation of Labor. Years after the campaign, Carey McWilliams noted seeing "slogans of EPIC campaign painted on rocks in the desert, carved on trees in the forests, and scrawled on walls of labor camps in the

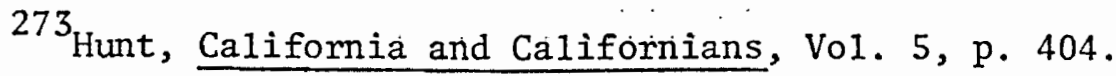

${ }^{274}$ McWilliams, Southern Califormia Country, p. 311

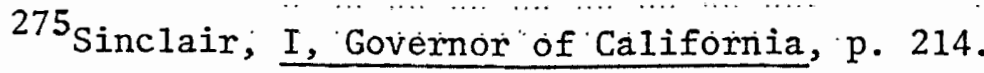


San Joaquin Va11ey. 276

In reflecting upon the 1934 gubernatorial election, Sinclair declared, "We did win. We gave California and all other states an exciting awareness of what Democracy really is." 277 Many individuals appreciated Sinclair's efforts because "one man" had the "courage to stand up" and fight the poverty and social ills without "consulting any boss...or any financier or capitalist..." 278 In 1963 in Los Angeles, Upton Sinclair stated after twenty-eight years:

I had all the facts on my side--and, likewise, a11 the fun. I can say that EPIC changed the political color of California; it scared the reactionaries out of their wits, and never in twenty-eight years have they dared go back on their old practices. 279

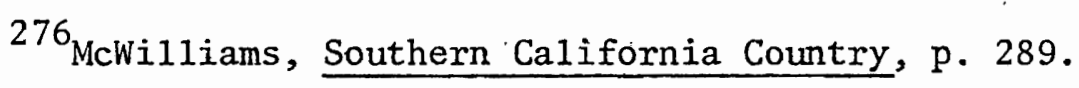

277 Leon Harris, Upton Sinclair: American Rebe1, p. 319.

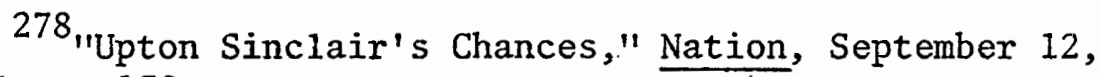
1934, p. 130.

${ }^{279}$ Sinclair, The Autobiography of Upton Sinclair, p. 274. 
CHAPTER VII

A COMPREHENSIVE RESOURCE GUIDE ON UPTON SINCLAIR AND THE 1934 CALIFORNIA GUBERNATORIAL ELECTION

In researching the 1934 gubernatorial election a wealth of materials were located, but not all were cited in the text of this thesis. The following comprehensive list of resources provides detailed bibliographic information and indicates availability of resources on the west coast where data can be obtained for future recreational or research endeavors.

BOOKS

Anderson, Dewey. Voting in California. Washington, D.C.: Public Affairs Institute, 1958.

Available: Los Angeles Pub1ic Library, Los Angeles, California.

Barck, Oscar Theodore Jr., and Blake, Nelson Manfred. Since 1900: A History of the United States in Our Times. 5th ed. New York: Macmillan Publishing Co., 1974.

Available: Los Angeles Public Library, Los Angeles, California.

Bean, Walton. California: An Interpretive History. New York: McGrawHill, $197 \overline{3 .}$

Available: Los Angeles Public Library, Los Angeles, California.

Beck, Warren A., and Williams, David A. California: A History of the Golden State. New York: Doubleday \& Co., 1972.

Available: Los Angeles Public Library, Los Angeles, California. 
Blinderman, Abraham, ed. Critics on Upton Sinclair. Readings in Literary Criticism Series, No. 24. Miami: University of Miami Press, 1975.

Available: University of Southern California, Los Angeles, California.

Borough, Reuben W. Challenge of Sinclair's EPIC. Los Angeles: By the Author, 1945.

Available: University of California, Los Angeles, California.

- Reuben W. Borough and the California Reform Movements.

Los Angeles: Unversity of California, 1968.

Available: University of California, Los Angeles, California.

Brogan, Dennis W. The Era of Franklin D. Roosevelt. New Haven, Mass.: Yale University Press, 1950.

Available: Portland State University, Portland, Oregon.

Burke, Robert E. Olson's New Deal for California. Los Angeles:

University of California, 1953.

Available: Portland State University, Portland, Oregon.

Burns, James MacGreger. Roosevelt: The Lion and the Fox. New York: Harcourt, Brace \& Co., 1956.

Available: Los Angeles Public Library, Los Angeles, California.

California Emergency Relief Administration. Economic Trends in Ca1ifornia, 1929-34. San Francisco: Califormia Emergency Relief Administration, 1935.

Available: University of Southern California, Los Angeles, California.

Carlson, Oliver A. Mirror for Californians. New York: Bobbs-Merrill Co., 1941.

Available: Los Angeles Public Library, Los Angeles, California; and Multnomah County Library, Portland, Oregon.

Caughey, John W. California. 3rd ed. Englewood Cliffs, N.J.: Prentice-Ha1 1970.

Available: Los Angeles Public Library, Los Angeles, California. 
Caughey, John W. Califormia. New York: Prentice-Hall, 1953.

Available: Multnomah County Library, Portland, Oregon.

Cleland, Robert Glass. 'Califormia in Our 'Time. New York: Alfred A. Knopf, 1947.

Available: Los Angeles Public Library, Los Angeles, California; and Multnomah County Librarv. Portland. Oregon.

Commonwealth Club of California. The Population of California.

San Francisco: Parker Printing Co., 1946.

Available: Los Angeles Public Library, Los Angeles, Califormia.

Cree1, George. Rebel at Large: Recollections of Fifty Crowded Years. New York: Putnam \& Sons, $1 \overline{947 .}$

Available: Los Angeles Public Library, Los Angeles, California.

Cresap, Dean R. Party Politics in the Golden State. Los Angeles: Haynes Foundation, 1954.

Available: Multnomah County Library, Portland, Oregon.

Crouch, W.W. California Government and Politics. New Jersey: Prentice-Ha11, 1967.

Available: Portland State University, Portland, Oregon.

De11, Floyd. Upton Sinclair: A Study in Social Protest. New York: Prentice-Hall, 1970.

Available: University of Southern California, Los Angeles, California.

Delmatier, R.D.; McIntosh, Clarence; and Waters, Earl.' Rumble of California Politics, 1848-1970. New York: Wiley छ Sons, 1970.

Available: Portland State University, Portland, Oregon.

Durrenberger, Robert W. California: Its People, its Problems; its

Prospects. New York: National Press Books, 1971.

Available: Oregon Historical Society, Portland, Oregon.

Evans, I.O. An Uptón Sinclair Anthology. London: T. Werner Laurie Ltd., $1 \overline{934 .}$

Available: Multnomah County Library, Portland, Oregon. 
Farre11y, David, and Hinderaker, Ivan. 'Politics of California: 'A Book of Readings. New York: Ronald Press Co., 1951.

Available: Portland State University, Portland, Oregon.

Fehrenbacker; Don E. A Basic History of California. New York: Van Nostrand Co., 1964.

Available: Los Angeles Public Library, Los Angeles, California.

Filler, Louis. Crusaders for American Liberalism. Yellow Springs, Ohio: Antioch, 1939.

Available: Los Angeles Public Library, Los Angeles, California.

Finney, Guy Woodward. Angel City in Turmoil. Los Angeles:

American Press, $1 \overline{945 .}$

Available: University of Southern California, Los Angeles, California.

Flynn, John R. The Roosevelt Myth. New York: Gardner City Books, 1948 .

Available: Los Angeles Public Library, Los Angeles, California; and Multnomah County Library, Portland, Oregon.

Giannini, A.P. Giant in the West. New York: Prentice-Hal1, 1947.

Available: Los Angeles Public Library, Los Angeles, California.

Gosne11, Harold. Grass Root Politics: National Voting Behavior of Typical states. New York: Russe11, 1970.

Availalbe: Los Angeles Public Library, Los Angeles, California.

Gottesman, Rona1d, ed. A Catalogue of Books, Mariscripts, and Other Materials from the Upton Sinclair Archives. Bloomington, Ind.: Indiana University, 1963.

Available: Los Angeles Public Library, Los Angeles, California.

Graham, Otis. New Deal: The Critical Issues. Boston: Little, Brown, \& Co., 1971 .

Available: Portland State University, Portland, Oregon.

Great Deceit:' Social Pseudo-Sciences. New York: Veritas Foundation, 1964.

Available: Los Angeles Public Library, Los Angeles, California. 
Greer, Thomas H. What Roosevelt Thought. Michigan: Michigan State University Press, 1958.

Available: Multnomah County Library, Portland, Oregon.

Harris, J.P. California Politics. New York: Thomas Y. Crowe1l, 1975. Available: Portland State University, Portland, Oregon.

Harris, Leon. Upton Sinclair: American Rebel. New York: Crowell, 1975 .

Available: Portland State University, Portland, Oregon.

Hill, Gladwin. Dancing Bear: An Inside Look at California Politics. Cleveland: World Publishing Co., 1968.

Available: Los Angeles Public Library, Los Angeles, California.

Hunt, Rockwe11 D., ed. California and Californians. Vol. 5. San Francisco: Lewis Publishing Co., 1926.

Available: University of Southern California, Los Angeles, California.

Hunt, Rockwell D., and Sanchez, Nellie Van de Grift. 'A Short History of California. New York: Macmillan, 1929.

Available: Los Angeles Public Library, Los Angeles, California.

Hyink, Bernard; Brown, Leyon; and Thacker, Ernest. 'Politics and Government in California. New York: Thomas Y. Crowe11 Co.,

Available: Portland State University, Portland, Oregon.

Ickes, Harold. The Secret Diary of Harold Ickes, the First Thousand Days. New York: Simon \& Schuster, 1953.

Available: Los Angeles Public Library, Los Angeles, California.

James, Marquis, and James, Bessie. Biography of a Bank: The Story of the Bank of America, N.T. \& S.A. New York: Harper and Bros., 1954 .

Available: Los Angeles Public Library, Los Angeles, California.

Johnpo11, B.K. Pacifist's Progress: Norman Thomas and the Decline of American Socialism. Chìcago: Quadrangle, 1970.

Available: Port1and State University, Portland, Oregon. 
Jordon, Frank C., comp. Statement of the Vote for the General Election. Sacramento, Calif.: State Printing Office, 1934. Available: Los Angeles. Public Library, Los Angeles, California. - Statement of the Vote for the Presidential General Election. Sacramento, Calif.: State Printing Office, 1932. Available: Los Angeles Public Library, Los Angeles, California. - Statement of the Vote for the Primary Election: Sacramento, Calif.: State Printing Office, 1934. Available: Los Angeles Public Library, Los Angeles, California.

Kelly, Stanley Jr. Public Relations and Political Power. Baltimore: Johns Hopkins Press, 1956.

Available: Los Angeles Public Library, Los Angeles, California.

Kunitz, Stanley J., and Haycroft, Howard, ed. Twentieth Century Authors. New York: H.W. Wilson Co., 1942.

Available: Portland State University, Portland, Oregon.

Lee, Eugene C. California Votes, 1928-60. Berkeley, Calif.: University of California, 1963.

Available: Los Angeles Public Library, Los Angeles, California; and Portland State University, Portland, Oregon.

Lyons, E. The Red Decade: The Classic. Work on Communism in America during the 1930's. New York: Doubleday, 1945.

Available: Portland State University, Portland, Oregon.

McWilliams, Carey. California: The Great Exception. New York: Current Books, 1949 .

Available: Los Angeles Public Library, Los Angeles, California. - Factories in the Field. Boston: Little, Brown \& Co., 1939.

Available: Multnomah County Library, Portland, Oregon. Pearce, 1946 .

Available: Multnomah County Library, Portland, Oregon. 
Melendy, H. Brett, and Gilbert,: Benjamin. The Governors of California from Peter H. Burnett to Edmund G. Brown. Georgetown, Ga.:

Talesman Press, 1965.

Available: Los Angeles Public Library, Los Angeles, California.

Nava, Julian. California: Five Centuries of Cultural Contests:

Beverly Hills, Calif.: Glencoe Press, 1976.

Available: Los Angeles Public Library, Los Angeles, California.

Neylan, John. 'Politics, Law, and the University of California.

Berkeley, Calif.: University of California, 1961.

Available: University of Southern California, Los Angeles, California.

Owens, John R.; Costantine, Edmund; and Weschur, Louis. California Politics and Parties. London: Macmillan, 1970.

Available: Portland State University, Portland, Oregon.

Parrington, Vernon L. Jr. American Dreams, a Study of American Utopias. New York: Russe11 \& Russe11, 1964.

Available: Los Angeles Public Library, Los Angeles, California.

Perkins, Francis. Rooseve1t I Knew. New York: Viking Press, 1946.

Available: Los Angeles Public Library, Los Angeles, Califormia.

Proof that Upton Sinclair Preaches Revolution and Communism. His Record and His Activities in Behalf of Communism. Los Angeles:

United for California League, 1934.

Available: University of Southern California, Los Angeles, California.

Reeves, Earl. Truth about the New Deal. New York: Longmans, Green and Cox, 1936.

Available: Los Angeles Public Library, Los Angeles, California.

Richmond, Al. Along View from the Left: Memoirs of an American

Revolutionary. New York: Thomas Y. Crowell, 1972.

Available: Portland State University, Portland, Oregon. 
Rocq, Margaret Miller. California Local History: A Bibliography and Union List of Library Holdings. San Francisco: Stanford University Press, 1976.

Available: Los Angeles Pub1ic Library, Los Angeles, California; and Oregon Historical Society, Portland, Oregon.

- California Local History: A Bibliography and Union List of Library Holdings. San Francisco: Stanford University Press, 1970 .

Available: Los Angeles Public Library, Los Angeles, California; and Oregon Historical Society, Portland, Oregon.

Rogin, Michael, and Shover, John L. Political Change in California: Critical Elections and Social Movements, 1890-1966. Westport, Conn.: Greenwood Pub., 1970.

Available: Portland State University, Portland, Oregon.

Rolle, Andrew F. California: A History. New York: Thomas Y. Crowell Co., 1969.

Available: Los Angelés Public Library, Los Angeles, California.

Rooseve1t, Elliott, ed. F.D.R.: His Personal Letters. New York: Duel1, Sloan and Pearce, 1950.

Available: California State University, Northridge, California; and Los Angeles Public Library, Los Angeles, California.

Rosten, Leo. Hollywood: The Movie Colony, the Movie Makers. New York: Harcourt, Brace \& Co., 1941.

Available: California State University, Northridge, California; and Los Angeles Pub1ic Library, Los Angeles, California.

Schlesinger, Arthur M. Jr. Politics of Upheave1: The Age of Roosevelt. Boston: Houghton Mifflin Co., 1960.

Available: Los Angeles Public Library, Los Angeles, California; and Portland State University, Portland, Oregon.

Schulberg, Budd. What Makes Sammy Run. New York: Random House, 1952.

Available: Los Angeles Public Library, Los Angeles, California.

Shulman, Irving. Harlow, an Intimate Biography. New York: Bernard Geis Associates, 1964 .

Available: Los Angeles Public Library, Los Angeles, California. 
Sinclair, John S. A Half Century of Government Spending. New York: National Industrial Conference Board, Inc., 1949.

Available: Multnomah County Library, Portland, Oregon.

Sinclair, Mary Craig. Southern Belle. Phoenix, Arizona: Sinclair Press, 1962.

Available: Los Angeles Public Library, Los Angeles, California.

Sinclair, Upton. American Outpost. New York: Farrar and Rinehart, 1932 .

Available: Los Angeles Public Library, Los Angeles, California; and Portland State University, Portland, Oregon.

- The Autobiography of Upton Sinclair. New York: Harcout, Brace \&World, 1962 .

Available: Los Angeles Public Library, Los Angeles, California.

- The Brass Check, A Study of American Journalism.

Pasadena, Calif.: By the Author, 1919.

Available: Los Angeles Public Library, Los Angeles, California.

- Epic Answers How to End Poverty in California. Los Angeles:

End Poverty League, 1933.

Available: Los Angeles Public Library, Los Angeles, California; and Portland State University, Portland, Oregon. 1934 .

- Epic Plan for California. New York: Farrar and Rinehart,

Available: Los Angeles Public Library, Los Angeles, California.

I, Candidate for Governor: And How I got Licked. Pasadena,

Calif.: By the Author, 1935.

Available: Portland State University, Portland, Oregon.

- I, Governor of California and How I Ended Poverty: A True

Story of the Future. New York: Farrar and Rinehart, 1933.

Available: Portland State University, Portland, Oregon.

- Immediate EPIC: The Final Statement of the Plan. Los

Angeles: End Poverty League, 1934.

Available: Los Angeles Public Library, Los Angeles, California. 
-The Industrial Republic: A Study of the America of Ten

Years Hence. New York: Harcourt, Brace \& World, 1907.

Available: Los Angeles Public Library, Los Angeles, California.

- Letters to Judd, and American Workingman. Pasadena, Calif.:

By the Author, 1926.

Available: Los Angeles Public Library, Los Angeles, California.

- The Lie Factory Starts: Los Angeles: End Poverty: League, 1934 .

Available: Portland State University, Portland, Oregon.

- My Lifetime in Letters. Columbia, Mo.: University of

Missouri Press, 1960.

Available: Portland State University, Portland, Oregon.

- Oil! New York: Farrar and Rinehart, 1927.

Available: Los Angeles Public Library, Los Angeles, California.

- The Profits of Religion: An Essay in Economic Interpreta-

tion. Pasadena, Calif.: By the Author, 1918.

Available: Los Angeles Public Library, Los Angeles, California; and Portland State University, Portland, Oregon.

- The Way Out: What Lies Ahead for America. Los Angeles:

By the Author, 1933.

Available: University of Southern California, Los Angeles, California.

- We, People of America: And How We Ended Poverty. Pasadena,

Calif.: National Epic League, 1936.

Available: Portland State University, Portland, Oregon.

Sover, Edwin R. Tournament of Roses, the Rose Bowl Game, Our First

70 Years. Pasadena, Calif.: Pasadena Planning Commission, 1959.

Available: Los Angeles Public Library, Los Angeles, California.

Tugwe11, Rexford G. The Democratic Roosevelt. New York: Doubleday, 1957.

Available: Portland State University, Portland, Oregon. 
Turner, Henry A., and Vieg, John:A. 'Government and Politics of Cálifornia. New York: McGraw-Hill, 1967.

Available: Portland State University, Portland, Oregon.

U.S. Department of Commerce. Historical Statistics of the United States: Colonial Times to 1970 . Bicentennial ed. Washington, D.C.: Government Printing Office, 1975.

Available: Portland State University, Portland, Oregon.

Unofficial Observer. American Messiahs. New York: Simon \& Schuster, 1935 .

Available: Los Angeles Public Library, Los Angeles, California.

Upton Sinclair: Democratic Candidate for Governor. Los Angeles: End Poverty League, Inc., 1934.

Available: Los Angeles Public Library, Los Angeles, Califormia. Upton Sinclair's Attitude on Christianity. Los Angeles: United for . California League, 1934.

Available: University of Southern California, Los Angeles, California.

Van de Vander, Charles. The Big Bosses. New York: Howell, Soskin, 1944 .

Available: Los Angeles Public Library, Los Angeles, California.

Voorhis, Jerry. Confessions of a Congressman. New York: Doubleday \& Co., 1947.

Available: California State University, Northridge, California. Whiteman, Luther, and Lewis, Samue1. Glory Roads: The Psychological State of California. New York: Thomas Y. Crowe11, 1936.

Available: Portland State University, Portland, Oregon; and University of Southern California, Los Angeles, California.

Yoder, Jon A. Upton Sinclair. New York: Fredrick Ungar Publishing Co., 1975.

Available: Los Angeles Public Library, Los Angeles, California. 
NEWSPAPERS

Alturas P1aindealer, January 1-November 6, 1934.

This paper underwent several title changes in the period examined. From January 4, 1929 to December 26, 1934, the paper was called the Alturas Plaindealer, followed by the Alturas Plaindealer and Modoc County Times, January 2, 1935; which was bought by the Modoc County Record on March 6, 1952 and renamed the Modoc County Record and Alturas Plaindealer.

Available: California State Library, Sacramento, California. Bakersfield Californian, January 1-December 31, 1934.

Available: California State Library, Sacramento, California. Chico Record, January 2, 1933-December 31, 1934.

Available: California State University, Northridge, California. Christian Science Monitor, January 2-December 31, 1934.

Available: Los Angeles Public Library, Los Angeles, California; and Portland State University, Portland, Oregon.

EPIC News, December 26, 1933-December 31, 1934.

For reference in this paper all variations in this newspaper title will be referred to as EPIC News. The title underwent a series of changes, being known as the End Poverty Paper from December 26, 1933 to May 1934; EPIC News, May 28, 1934 to May 27, 1935; and National EPIC, June 3, 1935 to January 27,1936 .

Available: California State Library, Sacramento, California; and Los Angeles Public Library, Los Angeles, California.

Fresno Bee, January 1-December 31, 1934.

Available: Los Angeles Public Library, Los Angeles, California. Hollywood Reporter, January 1-December 31, 1934.

Available: Los Angeles Public Library, Los Angeles, California. Los Angeles Hèra1d and Express, January 1, 1933-December 31, 1934.

Available: Los Angeles Public Library, Los Angeles, California. 
Los Angeles Times, January 1, 1933-December 31, 1934.

Available: Los Angeles Public Library, Los Angeles, California. New York American, January 1-November 6, 1934.

Available: Microphoto Division, Bell and Howell. New York Times, January 1, 1933-Decmeber 31, 1934.

Available: Los Angeles Public Library, Los Angeles, California; and Portland State University, Portland, Oregon.

Sacramento Bee, March 1, 1933-December 31, 1934.

Available: University of California, Los Angeles, Califomia. San Francisco Chronicle, March 1, 1933-December 31, 1934.

Available: Califronia State Library, Sacramento, CaIifornia. Western Worker, January 1-November 6, 1934.

Available: University of Southern California, Los Angeles, California.

\section{PERIODICALS}

The following availablity references are given for only those periodicals cited from public and university libraries outside of Oregon.

Ainsworth, Ed. "Remembering Uppie." Saturday Review, September 30, 1967, pp. 32-33.

Allen, Dever. "Do Socialists Want Socia1ism?" Christian Century, October 3, 1934, pp. 1249-50.

Ames, Richard Sheridan. "The Screen Enters Politics." Harper's Magazine, October 17, 1934, pp. 473-82.

Antognini, Richard. "The Role of A.P. Giannini in the 1934 California Gubernatorial Election." Southern California Quarterly, LVII (Spring, 1975), 63-86.

Available: Los Angeles Public Library, Los Angeles, California.

Badger, Sherwin 0. "Uptonia: California Millenium." Barron's, October 2, 1934, p. 2 . 
Available: Los Angeles Pub1ic Library, Los Angeles, Ca1ifornia.

Barger, Bob. "Raymond L. Haight and the Commonwealth Progressive Campaign of 1934." California Historical Society Quarterly, XLIII (September, 1964);219-30.

Available: Los Angeles Public Library, Los Angeles, California. "California Climax." Time, October 22, 1934, p. 13.

"California Here I Run." Time, October 15, 1934, p. 61.

"Can Sinclair Win?" Today, October 6, 1934, p. 20.

Coe, George A. "End Poverty in California." The World Tomorrow, March 29, 1934, pp. 159-60.

Available: University of Southern California, Los Angeles, California.

Cree1, George. "Utopia Unlimited." Saturday Evening Post, October 27, 1934, pp. 5, 78 .

Davenport, Walter. "Sinclair gets the Glory Vote." Collier's Magazine, October 27, 1934, pp. 12-13, 32-36.

Available: University of Southern California, Los Angeles, California.

De Ford, Miriam Allen. "San Francisco: An Autopsy on the General Strike." Nation, August 1; 1934, pp. 12-18.

Dempster, Milen. "From the Socialist Candidate for Governor of California." The World Tomorrow, May 10, 1934, pp. 262-63.

Available: University of Southern California, Los Angeles, California.

"Diogenes." Literary Digest, September 8, 1934, p. 13.

"Do Socialists Want Socialism?" Christian Century, September 8, 1934, p. 13.

"Epic Nomination: Political Importance of Sinclair's Victory." Christian Century, September 12, 1934, pp. 135-36.

"The Epic of Upton Sinclair." Nation, October 31, 1934, pp. 495-96. "EPIC Upton." Living Age, March 1934, pp. 180-81.

Available: Los Angeles Public Library, Los Angeles, California. 
"Estimated Population of California Counties.". Tax Dìgest, : XII (February, 1934), 59-65.

Available: Los Angeles Public Library, Los Angeles, California.

Foote, Robert Orlway. "The Radical vs. Conservative Issue on California." Literary Digest, September 8, 1934, pp. 7-8.

Gregg, James E. "Newspaper Editorial Endorsements and California Elections." Journalism Quarterly, XLII (Autum, 1965), 532-38.

Available: Los Angeles Public Library, Los Angeles, California.

Grenier, Judson. "Upton Sinclair: A Rememberance." California Historical Society Quarterly, XLVIII (June, 1969), 165-69.

Available: Los Angeles Public Library, Los Angeles, California. . "Upton Sinclair: The Road to California." Southern California Quarterly, LVI. (Winter, 1974) 325-36.

Available: Los Angeles Public Libraxy, Los Angeles, California.

Hennings, Robert E. "California Democratic Politics in the Period of Republican Ascendancy.". Pacific Historical Review, XXXI (August, 1962), 267-80.

Herring, Hubert C. "California Votes for God." Christian Century, October 31, 1934, pp. 1370-72.

"Industrial Truce to Face as Election Nears." Literary Digest, October 13, 1934, p. 3 .

"Issues and Men: Upton Sinclair Startles California." Nation, July 11, 1934, p. 35 .

Larson, Charles E. "Epic Campaign of 1934." Pacific Historical Review, XXVII (May, 1958), 127-29.

"Laski on Sinclair." Living Age, November 1934, pp. 276-77.

Available: Los Angeles Public Library, Los Angeles, California.

McHenry, Dean E. "The Pattern of California Politics." Western Political Quarterly, I (March, 1948), 44-53.

Available: Los Angeles Public Library, Los Angeles, California.

McWilliams, Carey. "Government by:Whitaker and Baxter." Nation, April 14, 1951, pp. 346-48; Apri1 21, 1951, pp. 366-68; and May 5, 1951, pp. 419-21. 
"High Spots in the Campaign." New Republic, November 7, 1934, pp. 616-17.

. "Sinclair Wanes." New'Republic, November 7, 1934, p. 356.

- "Upton Sinclair and His EPIC." New Republic, August 15, 1934, pp. 39-41.

Mason, Bruce B. "After Two Decades, a Look Back at Upton Sinclair's EPIC Scheme." Frontier, VI (August, 1955), 12-13.

"The EPIC Movement." Arizona Quarterly, XI (Winter, 1955), 320-31.

Available: Los Angeles Public Library, Los Angeles, California.

"Merriam Tops Sinclair in Final Poll Report." Literary Digest,

November 3, 1934, pp. 5, 43.

Moley, Raymond. "Looking Backward with Mr. Sinclair and Mr. Hoover." Today, October 6, 1934, pp. 5-13.

Avaiable: University of Southern California, Los Angeles, California.

"Monthly Bulletin on Relief Statistics." California State Emergency Relief Administration, I (August, 1934), 10 .

Available: California State Library, Sacramento, California.

Murdock, Steve. "California Communists--their Years of Power." Science and Society, XXXIV (Winter, 1970), 478-87.

Available: Los Angeles Public Library, Los Angeles, California.

"News and Comments from the Nation's Capito1." Literary Digest, June 30, 1934, p. 13.

"No Contest." Time, November 5, 1934, p. 12.

Norris, George W., and Sinclair, Upton. "Reforms Urged by Two Outstanding Figures." Literary Digest, October 18, 1934, pp. 8-9.

"Nothing Else to do." Time, September 10, 1934, p. 13.

Pitche11, Robert J. "Reapportionment as a Control of Voting in California." Western Political Quarterly, XIV (March, 1961), 214-35.

Available: Los Angeles Public Library, Los Angeles, California. 
"The Political Scene." Literary Digest, September 8, 1934, p. 6. "Politics." Newsweek, November 3, 1934, p. 139.

Posner, Russell M. "A.P. Giannini and the 1934 Campaign in California." Southern California Quarterly, LVI (Winter, 1974), 295-99.

- "California's Role in the Nomination of Franklin D. Roosevel." California Historical Quarterly, XXXIX (June, 1960), 121-39.

Available: Los Angeles Public Library, Los Angeles, California. "Primaries Yield Political Hybrid." Newsweek, September 10, 1934, p. 5. Ross, Irwin. "The Supersalesmen of California Politics: Whitaker and Baxter." Harper's Magazine, July 1959, pp. 55-61.

Rotefsky, Herbert. "A Nomination." New Republic, August 14, 1934, p. 20.

"700 Miles of Debate Over Sinclair in California." Newsweek, October 27, 1934, pp. 9-10.

"Sinclair Behind in Digest Po11." Literary Digest, October 27, 1934, p. 5 .

Sinclair, Upton. "End Poverty in Civilization." Nation, September 26, 1934, pp. 331-42.

- "Epic Marches On." New Republic, December 11, 1935, p. 131. - "The Future of Epic." Nation, November 28, 1934, pp. 616-17. - "Open Letter." New Repub1ic, August 29, 1934, pp. 75-76. - "Remedy the Depression through a New Cooperative System." Literary Digest, October 13, 1934, pp. 8-9.

- "Upton Sinclair Hits Back." Nation, November 6, 1934, pp. 535-36.

"Upton Sinclair's Position." New Republic, September 12, 1934, pp. 132-33. p. 157 .

157. "The World as I Want." Forum and Century, September 1934, Available: Los Angeles Public Library, Los Angeles, California. 
Singer, Donald. "Upton Sinclair and the California Gubernatorial Campaign of 1934." Southern California Quarterly, LVI (Winter, 1974), 375-407.

Available: Los Angeles:Public Library, Los Angeles, California.

"Socialists and California." Christian Century, September 19, 1932, pp. 1316-17.

Soderbergh, Peter. "Upton Sinclair and Hollywood." Midwest Quarterly, XI (Winter, 1970), 173-91.

Available: California State University, Northridge, California.

Stewart, Kenneth. "Upton Sinclair and his EPIC Plan for California." Literary Digest, August 25, 1934, p. 10.

"The Story of Upton Sinclair." Christian Century, October 19, 1932, pp. $1274-75$.

Swing, Raymond Gram. "Epic of Upton Sinclair." Nation, October 31, 1934, pp. 495-96. p. 139 .

"Last Look at the Campaign." Nation, November 7, 1934,

. "Sinclair, LaFollette, Cutting." Nation, October 31, 1934, pp. $495-98$.

Symes, Lillian. "California: There she Stands." Harper's Magazine, February 1935, pp. 36-68.

"This Week." New Republic, November 7, 1934, p. 349.

Thomas, Norman. "American Socialism!s Weakest Link." The World Tomorrow, April 12, 1934, pp. 180-82.

Available: University of Southern California, Los Angeles, California.

"Upton Sinclair Describes his Evolution." New York Times Magazine, September 16, 1934, pp. 9, 17.

"Upton Sinclair's Chances." Nation, September 12, 1934, pp. 285-86.

"Upton Sinclair's Chances." New Repub1ic, September 12, 1934, p. 130.

"Upton Sinclair's Defeat." Christian Century, November 21, 1934, p. 101. "Upton Sinclair's Victory." Nation, September 12, 1934, pp. 285-86. 
Villard, Oswald G. "Upton Sinclair.Startles California." Nation, July 11,1934, p. 35.

West, George P. "California Sees' Red." Current History, September 1934, . pp. $658-62$.

Whitaker, Clem. "Professional Campaign Management." Public Relations Jourinal, VI (January, 1950), 19-21.

Available: Los Angeles Public Library, Los Angeles, California.

Whitaker, Clem, and Baxter, Leone. "Campaign Blunders Can Change History." Public Relations Journal, XII (August, 1956), 4-6, 19.

Available: Los Angeles Public Library, Los Angeles, California. Whitaker, Clem, and Baxter, Leone. "Election Year Coming Up." Public Relations Journal, XI (October, 1955), 11-12, 98-102.

Available: Los Angeles Public Library, Los Angeles, California. Wilson, Edmund. "Lincoln Stephens and Upton Sinclair." New Republic, September 8, 1932, pp. 173-74.

Zanger, Martin. "Upton Sinclair as California Socialist Candidate for Congress, 1920." Southern California Quarterly, LVI (Winter, 1974), 359-73.

Available: Los Angeles Public Library, Los Angeles, California.

\section{SPECIAL COLLECTIONS}

Duke University. Library, Socialist Party of America Collection.

Hyde Park, New York. Franklin D. Roosevelt Papers.

Indiana University. Lilly Library, Frederick W. and Lucile G. Nelson Collection of EPIC Materials.

Library of Congress. William Gibbs McAdoo Papers.

Occidental College. Library, Dr. Elmer Belt Collection on Upton Sinclair.

San Francisco, Califormia. Bank of America Archives, Giannini Papers. State Historical Society of Wisconsin. Library, Morris Hillguit Papers. 
University: of California, Berkeley. Bancroft Library, Diary of J.F.T. O'Connor.

. Bancroft Library, : R:V. Taggert Scrapbook of Republican Campaign Literature for the 1934 California Gubernatorial Campaign.

- Bancroft Library, Thomas J. Mooney Pamphlet Collection.

University of California, Los Angeles. Library, Franklin L. Hichborn Collection.

- University Research Library, John Randolph Haynes and Dora Haynes Foundation Collection.

UNPUBLISHED MATERIALS

Albrecht, Alfred James. "A Rehtorical Study of Upton Sinclair's 1934 Campaign for Governor of California." Unpublished M.A. thesis, Indiana University, 1961.

Available: California Historical Society Library, San Francisco, California; and University of Califomia, Davis, California.

Ashton, George Franklin. "Upton Sinclair." Unpublished M.A. thesis, University of California, Berkeley, 1951.

Available: University of California, Bancroft Library, Berkeley, Califormia.

Bell, Charles G. "A Study of Four Selected Factors which have Contributed to the Inability of the Democratic Party to Successfully Mobilize its Latent Majority in California." Unpublished M.A. thesis, University of California, Berkeley, n.d.

Available: California State University, Northridge, California.

Brazi1, Burton R. "Voting in California, 1920-1956." Unpub1ished M.A. thesis, University of California, Los Ange1-s, 1948.

Available: University of California, Berkeley, California; and University of California, Los Angeles, California.

Chinn, Ronald E. "An Analysis of the Structure and Function of the Democratic Party in California, 1920-56." Unpublished Ph.D. dissertation, University of California, Berkeley, 1957.

Available: University of California, Berkeley, California. 
- "The Sinclair Campaign of 1934." Unpublished M.A. thesis, Stanford University, 1937.

Available: Stanford University, Palo Alto, California.

Cresap, Dean R. "Party Organization in:California." Unpublished Ph.D. dissertation, Stanford University, 1952.

Available: Stanford University, Palo Alto, California.

Delmatier, Royce Deems. "The Rebirth of the Democratic Party in

California: 1928-38." Unpublished Ph.D. dissertation, University of California, Berkeley, 1956.

Available: University of California, Berkeley, California.

Fretz, Lewis A. "Upton Sinclair: The Don Quiote of American Reform." Unpublished Ph.D. dissertation, Stanford University, 1970.

Available: Stanford University, Palo Alto, California.

Goodman, William. "Culbert 01son and California Politics, 1933-43." Unpublished M.A. thesis, University of California, Los Angeles, 1948 .

Available: University of Califomia, Los Angeles, California.

Gordon, Robert Mattisen. "The EPIC Movement and the California Election of 1934." Unpublished M.A. thesis, College of the Pacific, 1957.

Available: University of the Pacific, Stockton, California.

Hichborn, Franklin. "Ca1iformia Politics, 1891-1939." Unpublished manuscript, Haynes Foundation, Los Angeles, 1939.

Available: University of California, Los Angeles, California.

Higgenbottom, George. "EPIC by the Bay." Unpublished M.A. thesis, University of California, Berkeley, n.d.

Available: University of California, Berkeley, California.

Knutsen, George E. "Upton Sinclair: The Urge to Reform." Unpublished M.A. thesis, University of Southern California, 1965.

Available: University of Southern California, Los Angeles, California.

Larsen, Charles E. "The EPIC Movement in California Politics, 1933-34." Unpublished M.A. thesis, University of California, Los Angeles, 1942. 
Available: University of California, Los Angeles; California.

Lee, Glynn B. "A Study of the Zenith of Evolutionary Socilaism in

California: Upton Sinclair and his Crusade of EPIC." Unpublished M.A. thesis, Chico State College, 1951.

Available: California State: University, Chico, California.

McIntosh, Clarence F. "Upton Sinclair and the EPIC Movement, 1933-36." Unpublished Ph.D. dissertation, Stanford University, 1955.

Available: CaIifornia State University, Northridge, California.

MacMaster, Joan H. "The Dirtiest Campaign in California's History: The Defeat of Upton Sinclair and the EPIC Plan." Unpublished M.A. thesis, Sacramento State College, 1947.

Available: California State University, Sacramento, California.

Noah, Charles W. "California Politics during the Roosevelt Era, 193239." Unpublished M.A. thesis, University of Southern California, 1950.

Available: University of Southern California, Los Angeles, California.

Pitche11, Robert Joseph. "Twentieth Century Voting Behavior." Unpub1ished Ph.D. dissertation, University of California, Berkeley, 1955.

Available: University of California, Berkeley, California.

Posner, Russel1. "State Politics and the Bank of America, 1920-34." Unpublished $\mathrm{Ph} . \mathrm{D}$. dissertation, University of California, Berkeley, 1956.

Available: University of California, Berkeley, California.

Putnam, Jackson K. "The Influence of the Older Age Groups on California Politics, 1920-1940." Unpublished Ph.D. dissertation, Stanford University, 1964.

Available: University of California, Berkeley, California.

Riley, Richard James. "Upton Sinclair and the 1934 California Gubernatorial Election." Unpublished M.A. thesis, Chico State College, 1952.

Available: California State University, Chico, California. 
Rose, Alice. "The Rise of California Insurgency." Unpublished Ph:D. dissertation, Stanford University, 1942.

Available: Stanford University, Palo Alto, California.

Singer, Donald Lee. "Upton Sinclair and the California Gubernatorial Campaign of 1934." Unpublished M.A. thesis, University of Southern California, 1966.

Available: University of Southern California, Los Angeles, California.

Townsend, Helen M. "the History of the EPIC Movement, 1933-34." Unpublished M.A. thesis, University of Southem Califomia, 1940 .

Available: University of Southern California, Los Angeles, California. 


\title{
A SELECTED BIBLIOGRAPHY
}

\author{
BOOKS
}

Anderson, Dewey. Voting in California. Washington, D.C.: Public Affairs Institute, 1958.

Barck, Oscar Theodore Jr., and Blake, Nelson Manfred. Since 1900:- A History of the United States in Our Times. 5th ed. New York: Macmillan Publishing Co., 1974.

Bean, Walton. California: An Interpretive History. New York: McGraw-Hil1, 1973.

Beck, Warren A., and Williams, David A. California: A History of the Golden State. New York: Doub1eday \& Co., 1972.

Borough, Reuben M. Challenge of Sinclair's EPIC. Los Angeles: By the Author, $19 \overline{45 .}$

Brogan, Dennis W. The Era of Frank1in D. Rooseve1t. New Haven, Mass.: Yale University Press, 1950.

Burke, Robert E. O1son's New Deal for California. Los Angeles: University of Califomia, 1953.

Burns, James MacGreger. Roosevelt: The Lion and the Fox. New York: Harcourt, Brace \& Co., 1956.

Ca1ifornia Emergency Relief Administration. Economic Trends in California, 1929-34. San Francisco: California Emergency Relief Administration, 1935.

Carlson, Oliver A. Mirror for Californians. New York: Bobbs-Merrill Co., 1941.

Caughey, John W. California. New York: Prentice-Ha11, 1953.

Cleland, Robert Glass. California in Our Time. New York: Alfred A. Knopf, 1947.

Commonwealth Club of California. The Population of California. San Francisco: Parker Publishing Co., 1946. 
Cree1, George. Rebel at Large, Recollections of Fifty Crowded Years. New York: Putnam \& Sons, 1947.

Cresap, Dean R. 'Party Politics in the Golden State.' Los Angeles: Haynes Foundation, 1954.

Crouch, W.W. California Government and Politics. New Jersey: Prentice-Ha11, 1967.

Dell, Floyd. Upton Sinclair: 'A Study in Social Protest. New York: Prentice-Ha11, 1970.

Delmatier, R.D.; McIntosh, Clarence; and Waters, Earl. Rumble of California Politics, 1848-1970. New York: Wiley \& Sons, 1970 .

Farrelly, David, and Hinderaker, Ivan. Politics of California: A Book of Readings. New York: Ronald Press Co., 1951.

Fehrenbacker, Don E. A Basic History of California. New York: Van Nostrand Co., 1964.

Flynn, John R. The Roosevelt Myth. New York: Gardner City Books, 1948 .

Gosne11, Harold. Grass Root Politics: National Voting Behavior of Typica1 States. New York: Russe11, 1970.

Graham, Otis. New Deal: The Critical Issues. Boston: Little, Brown, \& Co. , $19 \overline{71 .}$

Great Deceit: Social Pseudo-Sciences. New York: Veritas Foundation, 1964 .

Harris, J.P. California Politics. New York: Thomas Y. Crowe11, 1975.

Harris, Leon. Upton Sinclair: American Rebel. New York: Crowe11, 1975.

Hunt, Rockwell D., ed. California and Californians. Vo1. 5. San Francisco: Lewis Publishing Co., 1926.

Hyink, Bernard; Brown, Leyon; and Thacker, Ernest. 'Politics and Government in California. New York: Thomas Y. Crowell Co., 1969.

James, Marquis, and James, Bessie. Biography of a Bank: The Story of the Bank of America; N.T. \& S. A. New York: Harper and Bros., 1954 .

Johnpoll, B.K. Pacifist's Progress: Norman Thomas and the Decline of American Socialism. Chicago: Quadrangle, 1970. 
Jordan, Frank C., comp. 'Statement of the Vote for the General Election. Sacramento, Calif.: State Printing Office, 1940.

- Statement of the Vote for the General Election. Sacramento, Calif.: State: Printing Office, 1938.

- Statement of the Vote for the General Election: Sacramento, Calif.: State Printing Office, 1936.

- Statement of the Vote for the General Election. Sacramento, Calif.: State Printing Office, 1934.

- Statement of the Vote for the General Election. Sacramento, Calif.: State Printing Office, 1932 .

- Statement of the Vote for the General Election. Sacramento, Calif:: State Printing Office, 1930.

- Statement of the Vote for the General Election. Sacramento, Calif.: State Printing Office, 1928.

- Statement of the Vote for the Presidential Election. Sacramento, Calif.: State Printing office, 1932.

- Statement of the Vote for the Primary Election. Sacramento, Calif.: State Printing office, 1940. - Statement of the Vote for the Primary Election. Sacramento, Calif.: State Printing Office, 1938.

- Statement of the Vote for the Primary Election. Sacramento, Calif.: State Printing Office, 1936.

- Statement of the Vote for the Primary Election. Sacramento, Calif.: State Printing Office, 1934.

- Statement of the Vote for the Primary Election. Sacramento, Calif.: State Printing Office, 1932.

- Statement of the Vote for the Primary Election. Sacramento, Calif.: State Printing Office, 1930.

- Statement of the Vote for the Primary Election. Sacramento, Calif.: State Printing Office, 1928.

Lee, Eugene C. 'California Votes, 1928-60. Berkeley, Calif.: University of Caifornia, 1963.

Lyons, E. The Red Decade: The Classic Work on Communism in America during the 1930's. New York: Doubleday, 1945. 
McWilliams, Carey. California: The Great Exception. New York: Current Books, 1949.

$\therefore$ Factories in the Field. Boston: Little, Brown and Co., 1939.

- Southern Califormia Country. New York: Due1l, Sloan and Pearce, 1946.

Melendy, H. Brett, and Gilbert, Benjamin. The Governors of California from Peter H. Burnett to Edmund G. Brown. Georgetown, Ga.: Talesman Press, 1965.

Nava, Julian. California: Five Centuries of Cultural Contests. Beverly Hills, Calif.: Glencoe Press, 1976.

Owens, John R.; Costantine, Edmund; and Weschur, Louis. California Politics and Parties. London: Macmillan, 1970.

Perkins, Francis. Roosevelt I Knew. New York: Viking Press, 1964.

Richmond, Al. Along View from the Left: Memoirs of an American Revolutionary. New York: Thomas Y. Crowe11, 1972.

Rogin, Michael, and Shover, John L. Political Change in California: Critical Elections and Social Movements, 1890-1966. Westport, Conn.: Greenwood Pub., 1970.

Ro1le, Andrew F. California: A History. New York: Thomas Y. Crowell Co., 1969.

Roosevelt, Elliott, ed. F.D.R.: His Personal Letters. New York: Due11, SIoan and Pearce, 1950.

Rosten, Leo. Hollywood: The Movie Colony, the Movie Makers. New York: Harcourt, Brace \& Co., 1941.

Schlesinger, Arthur M. Jr. Politics of Upheave1: The Age of Rooseve1t. Boston: Houghton Mifflin Co., 1960.

Sinclair, Upton. The Autobiography of Upton Sinclair. New York: Harcourt, Brace \& World, 1962.

.. The Brass Check, A Study of American Journalism. Pasadena, Ca1if.: By the Author, 1919.

- Epic Answers How to End Poverty in California. Los Angeles: End Poverty League, 1933. 1934 .

Epic Plan for California. New York: Farrar and Rinehart, 
- I Candidate for Govemor: And How I got Licked. Pasadena, Calif.: By the Author, 1935.

$\therefore$ I, Governor of California and How I Ended Poverty: A True

Story of the Future. New York: Farrar and Rinehart, 1933.

- Immediate EPIC: The Final Statement of the Plan. Los

Angeles: End Poverty League, 1934. 1934 .

The Lie Factory Starts. Los Angeles: End Poverty League,

- My Lifetime in Letters. Columbia, Mo.: University of Missouri Press, 1960.

- The Profits of Religion: An Essay in Economic Interpreta-

tion. Pasadena, Calif.: By the Author, 1918.

- The Way Out: What Lies Ahead for America. Los Angeles: By the Author, 1933.

Turner, Henry A., and Vieg, John A. Governments and Politics of California. New York: McGraw-Hil1, 1967.

Upton Sinclair: Democratic Candidate for Governor. Los Angeles: End Poverty League, 1934.

Van de Vander, Charles. The Big Bosses. New York: Howell, Soskin, 1944.

Whiteman, Luther, and Lewis, Samuel. Glory Roads: The Psychological State of California. New York: Thomas Y. Crowe11, 1936.

\section{NEWSPAPERS}

Alturas Plaindealer, January. 1-November 6, 1934.

Bakersfield Californian, January 1-December 31, 1934.

Chico Record, January 2, 1933-December 31, 1934.

Christian Science Monitor, January 2-December 31, 1934.

EPIC News, December 26, 1933-December 31, 1934.

Frèsno Bee, January 1-December 31, 1934.

Hollywood Reporter, January 1-December 31, 1934.

Los Angeles Herald and Express, January 1, 1933-December 31, 1934. 
Los Angeles Times, January 1, 1933-December 31, 1934.

New York American, January 1-Nov̈ember 6, 1934.

New York Times, January 1, 1933-December 31, 1934.

Sacramento Bee, March 1, 1933-December 31, 1934.

San Francisco Chronicle, March 1, 1933-December 31, 1934.

Western Worker, January 1-November 6, 1934.

\section{PERIODICALS}

Ainsworth, Ed. "Remembering Uppie." Saturday Review, September 30, 1967, pp. 32-33.

Antognini, Richard. "The Role of A.P. Giannini in the 1934 California Gubernatorial Election." Southern California Quarterly, LVII (Spring, 1975), 63-86.

Barger, Bob. "Raymond L. Haight and the Commonwealth Progressive Campaign of 1934." California Historical Society Quarterly, XLIII (September, 1964), 219-30.

"California Climax." Time, October 22, 1934, pp. 13-14.

"California Here I Run." Time, October 15, 1934, p. 61.

"Can Sinclair Win?" Today, October 6, 1934, p. 20.

Cree1, George. "Utopia Un1imited." Saturday Evening Post, October 27, 1934, pp. 5, 78 .

Dempster, Milen. "From the Socialist Candidate for Governor of

California." The World Tomorrow, May 10, 1934, pp. 262-63.

"The Epic of Upton Sinclair." Nation, October 31, 1934, pp. 495-96.

"Epic Upton." Living Age, March 1934, pp. 180-81.

"Estimated Population of California Counties." Tax Digest, XII (February, 1934), 59-65.

Foote, Robert Orlway. "The Radical vs. Conservative Issue on California." Literary Digest, September 8, 1934, pp. 7-8.

Gregg, James E. "Newspaper Editorial Endorsements and California Elections." Journalism Quarter1y, XLII (Autum, 1965), 532-38. 
Grenier, Judson. "Upton Sinclair: A Rememberance." Califoriia Historical Society Quärterly; XLVIII (June, 1969), 165-69.

. "Upton Sinclair: The Road to Califormia." "Southem California Quarter1y, LVI (Winter, 1974), 325-36.

Hennings, Robert E. "California Democratic Politics in the Period of Republican Ascendancy." Pacific Historical Review, XXXI (August, 1962), 267-80.

Herring, Hubert C. "California Votes for God." Christian Century, October 31, 1934, pp. 1370-72.

"Industrial Truce to Face as Election Nears." Literary Digest, October 13, 1934, p. 3.

Larson, Charles E. "Epic Campaign of 1934." Pacific Historical Review, XXVII (May, 1958), 127-229.

McHenry, Dean E. "The Pattern of California Politics." Western Political Quarterly, I (March, 1948), 44-53.

McWilliams, Carey. "High Spots in the Campaign." New Republic, November 7, 1934, pp. 616-17.

… "Upton Sinclair and His EPIC." New Republic, August 15, 1934, pp. 39-41.

"Merriam Tops Sinclair in Final Poll Report." Literary Digest, November 3, 1934, pp. 5, 43.

"Monthly Bulletin on Relief Statistics." California State Emergency Relief Administration, I (August, 19 $\overline{34), 10 .}$

Murdock, Steve. "California Communists--Their Years of Power." Science and Society, XXXIV (Winter, 1970), 478-87.

"No Contest." Time, November 5, 1934, p. 12.

"Politics." Newsweek, November 3, 1934, p. 139.

Posner, Russell M. ".P. Giannini and the 1934 Campaign in California." Southern California Quarterly, LVI (Winter, 1974), 295-99.

"700 Miles of Debate Over Sinclair in California." Newsweek, October 27, 1934, pp. 9-10.

Sinclair, Upton. "End Poverty in Civilization." Nation, September 26. 1934, pp. 331-42.

- "Epic Marches On." New Republic, December 11, 1934, p. 131. 
- "The Future of Epic." Nation, November 28, 1934, p. 616-17.

. "Open Letter." New Repüblic, August 29, 1934, pp. 75-76.

"Upton Sinclair Hits'Back." Nation, November 6, 1934, pp. $535-36$.

"Upton Sinclair's Position." New Republic, September 12, 1934, pp. 132-33.

Singer, Donald. "Upton Sinclair and the California Gubernatorial Campaign of 1934." Southern California Quarterly, LVI (Winter, 1974), 219-42.

Stewart, Kenneth. "Upton Sinclair and His EPIC Plan for California." Literary Digest, August 25,1934, p. 10.

Swing, Raymond Gram. "Epic of Upton Sinclair." Nation, October 31, 1934, pp. 495-96.

p. 139 .

"Last Look at the Campaign." Nation, November 7, 1934,

"Upton Sinclair's Chances." New Republic, September 12, 1934, p. 130.

"Upton Sinclair's Victory." Nation, September 12, 1934, pp. 285-86.

West, George P. "California Sees Red." Current History, September 1934, pp. 658-62.

Zanger, Martin. "Upton Sinclair as California Socialist Candidate for Congress, 1920." Southern California Quarterly, LVI (Winter, 1974), 359-73.

\section{SPECIAL COLLECTIONS}

Occidental College. Library, Dr. Elmer Belt Collection on Upton Sinclair.

University of California, Berkeley. Bancroft Library, Diary of J.F.T. o'Connor.

- Bancroft Library, R.V. Taggert Scrapbook of Republican

Campaign Literature for the 1934 California Gubernatorial Campaign.

- Bancroft Library, Thomas J. Mooney Pamphlet Collection.

University of California, Los Angeles. Library, Franklin L. 
Hichborn Collection.

- University Research Library, John Randolph Haynes and Dora Haynes Foundation Collection. 
APPENDIX A

ANALYSIS OF LITERARY DIGEST POLL BY COMMUNITIES

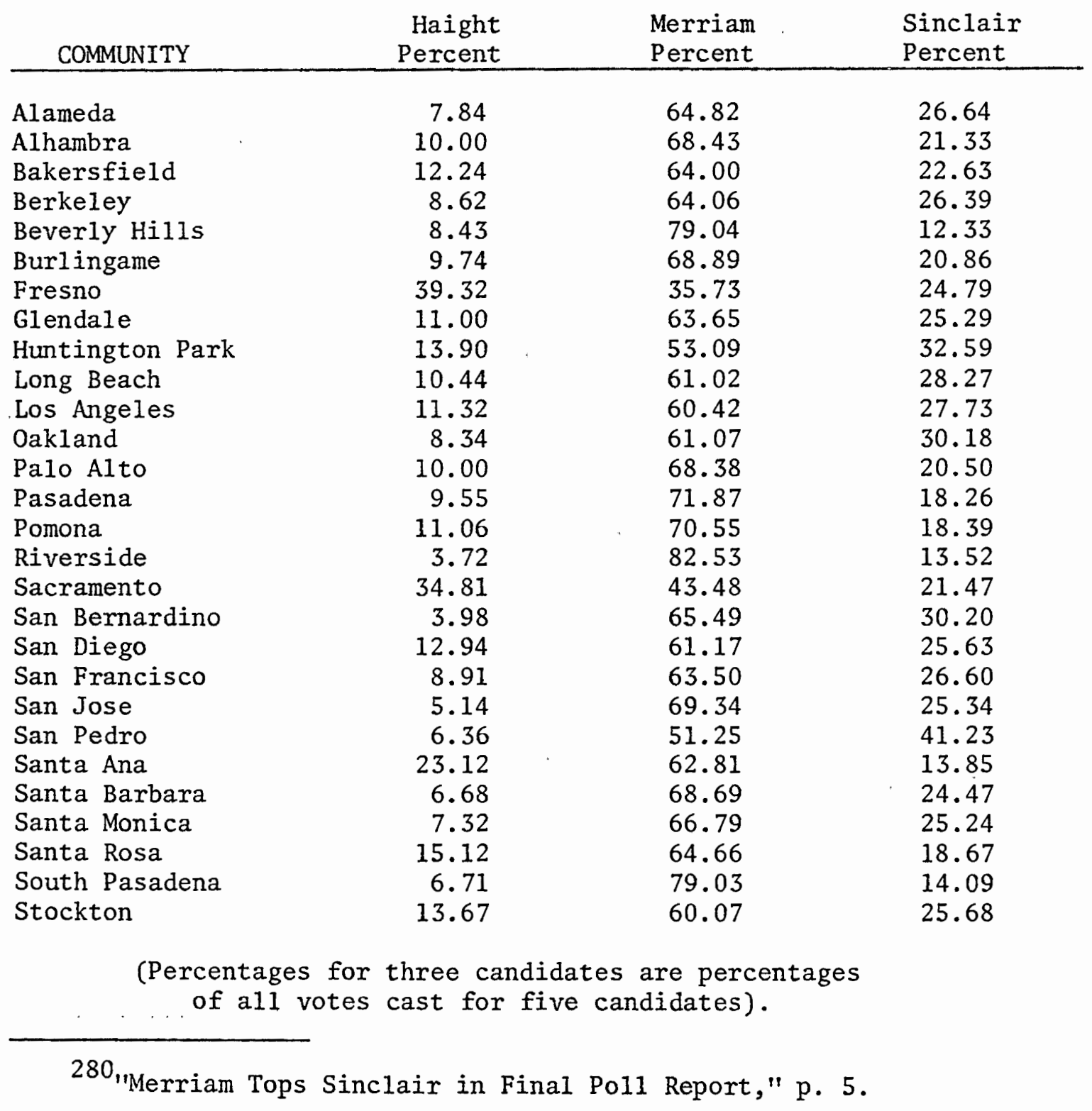


APPENDIX B

TOTAL VOTE BY PARTIES FOR THE

PRIMARY AND GENERAL ELECTIONS

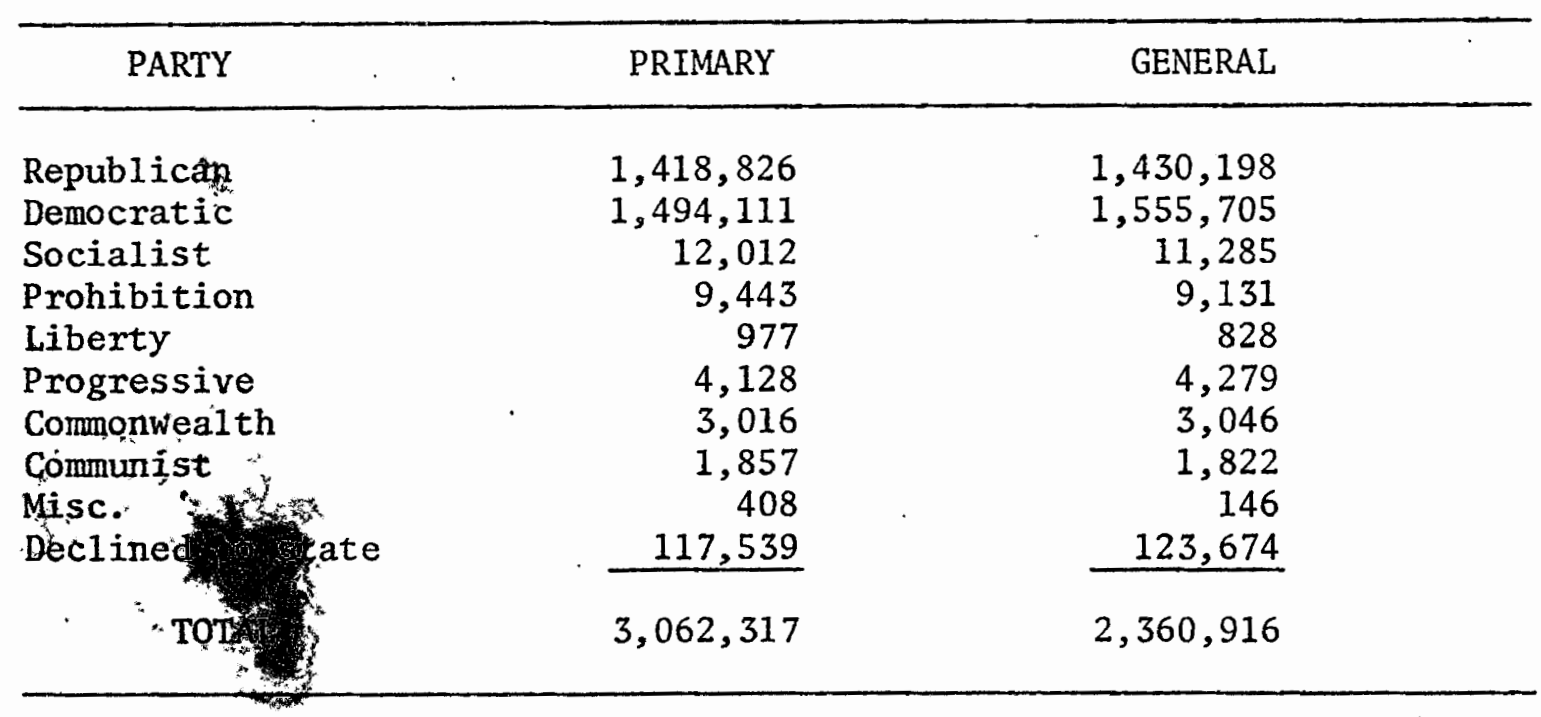

${ }^{281}$ Jordon, Frank C., comp., Statement of the Vote for the General Election (Sacramento, Calif.: State Printing Office, 1934), p. 45; Jordon, Statement of the Vote for the Primary Election, p. 5. 